
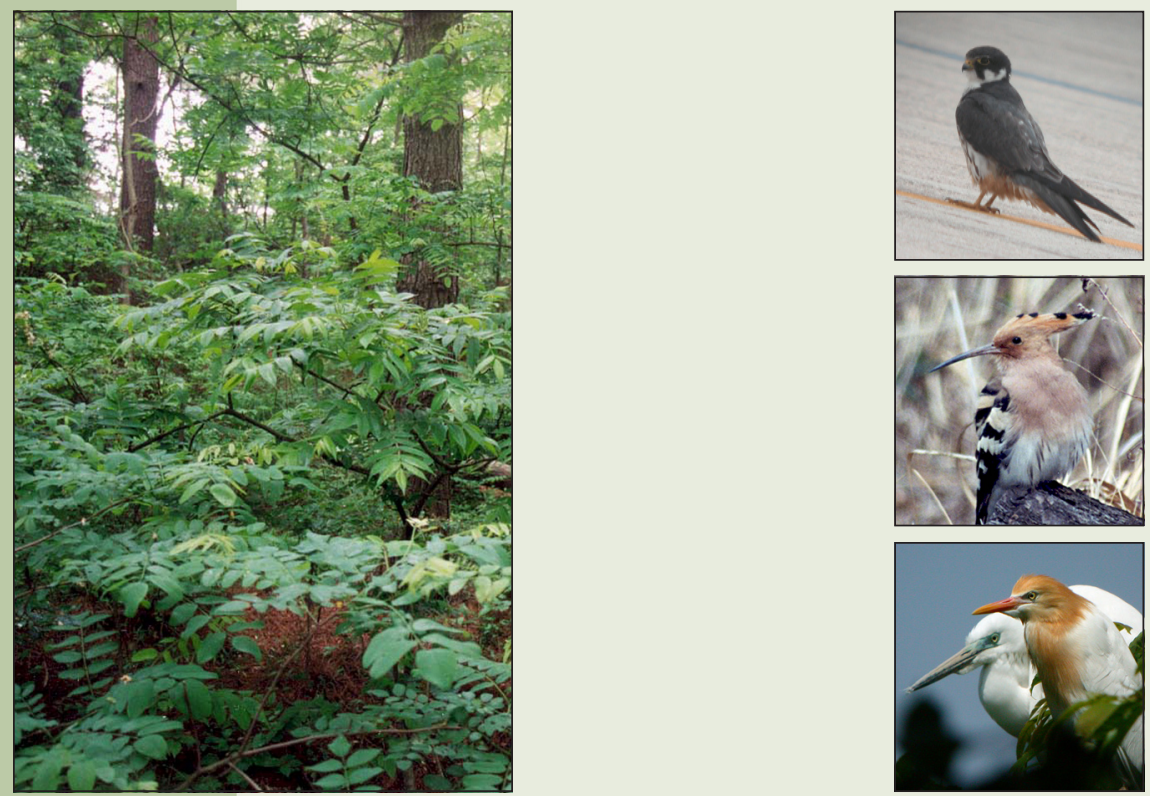

\title{
Avian Field Guide and Checklist for Kunsan Air Base, Korea
}

Environmental Flight

$8^{\text {th }}$ Civil Engineer Squadron

Kunsan Air Base, Republic of Korea

February 2006

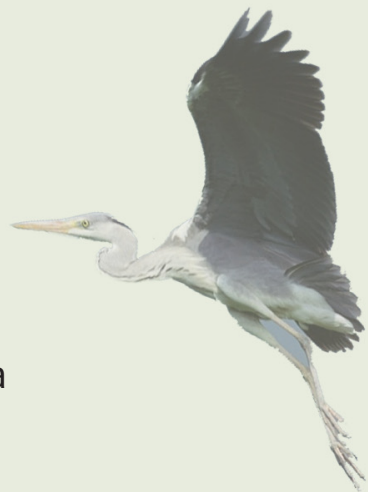




\section{Acknowledgements}

Prepared by James B. Levenson, Environmental Science Division, Argonne National Laboratory, Argonne, III. Work supported under Military Interdepartmental Purchase Requests (NFB52840100140, NFB528402000046, and NFB528404000102) from the U.S. Department of Defense, Department of the Air Force, 8th Civil Engineer Squadron, through U.S. Department of Energy contract W-31-109-Eng-38.

\section{About Argonne National Laboratory}

Argonne is managed by The University of Chicago for the U.S. Department of Energy under contract W-31-109-Eng-38. The Laboratory's main facility is outside Chicago, at 9700 South Cass Avenue, Argonne, Illinois 60439. For information about Argonne and its pioneering science and technology programs, see www.anl.gov.

\section{Disclaimer}

This report was prepared as an account of work sponsored by an agency of the United States Government. Neither the United States Government nor any agency thereof, nor The University of Chicago, nor any of their employees or officers, makes any warranty, express or implied, or assumes any legal liability or responsibility for the accuracy, completeness, or usefulness of any information, apparatus, product, or process disclosed, or represents that its use would not infringe privately owned rights. Reference herein to any specific commercial product, process, or service by trade name, trademark, manufacturer, or otherwise, does not necessarily constitute or imply its endorsement, recommendation, or favoring by the United States Government or any agency thereof. The views and opinions of document authors expressed herein do not necessarily state or reflect those of the United States Government or any agency thereof, Argonne National Laboratory, or The University of Chicago. 


\section{Avian Field Guide and Checklist for Kunsan Air Base, Korea}

by

J.Levenson

Environmental Science Division, Argonne National Laboratory

November 2005

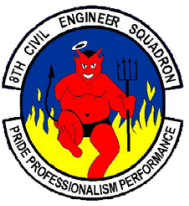





\section{Table of Contents}

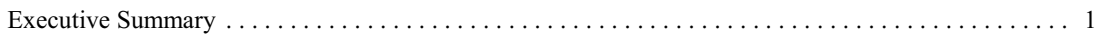

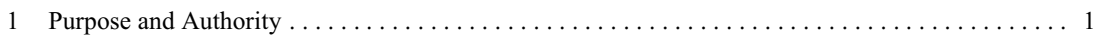

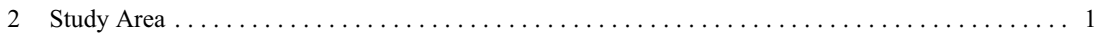

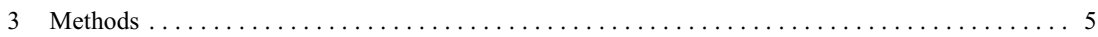

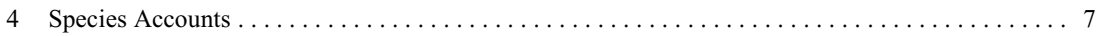

5 BASH (Bird Aircraft Strike Hazards) $\ldots \ldots \ldots \ldots \ldots \ldots \ldots \ldots \ldots \ldots \ldots \ldots \ldots \ldots \ldots \ldots \ldots$

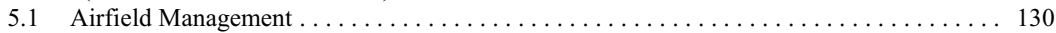

5.2 Drainage Ditch Maintenance $\ldots \ldots \ldots \ldots \ldots \ldots \ldots \ldots \ldots \ldots \ldots \ldots \ldots \ldots \ldots \ldots \ldots$

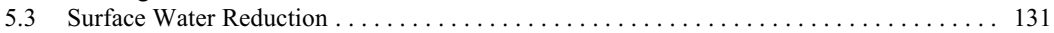

5.4 Alternative Mowing Equipment and Procedures $\ldots \ldots \ldots \ldots \ldots \ldots \ldots \ldots \ldots \ldots \ldots 132$

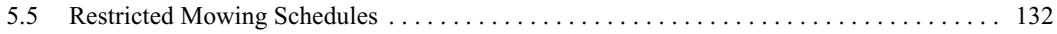

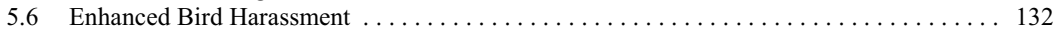

5.7 Eliminating Nesting and Roosting Birds $\ldots \ldots \ldots \ldots \ldots \ldots \ldots \ldots \ldots \ldots \ldots \ldots \ldots \ldots \ldots$

5.7 .1 Black-crowned Night Heron $\ldots \ldots \ldots \ldots \ldots \ldots \ldots \ldots \ldots \ldots \ldots \ldots \ldots \ldots \ldots \ldots$

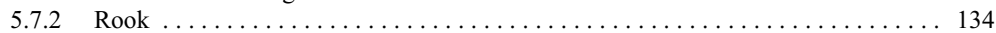

5.8 Airfield Attractants $\ldots \ldots \ldots \ldots \ldots \ldots \ldots \ldots \ldots \ldots \ldots \ldots \ldots \ldots \ldots \ldots \ldots \ldots \ldots$

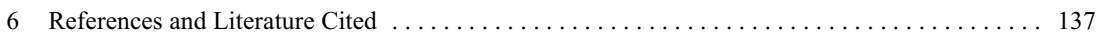

7 Index of Scientific and English Common Names $\ldots \ldots \ldots \ldots \ldots \ldots \ldots \ldots \ldots \ldots \ldots \ldots$

\section{List of Tables}

Table 1. Habitats and Subjective BASH Risks for Birds Found on Kunsan AB

\section{List of Figures}

Figure 1. Bird survey areas of Kunsan Air Base 
This Page

Intentionally

Blank 


\section{List of Abbreviations and Acronyms}

A

AB

AFKN

BASH

BHWG

Bldg.

C

CE

$\mathrm{cm}$

EGS

FW

ha

hrs

INRMP

$\mathrm{KACN}$

KAL

$\mathrm{km}$

$\mathrm{m}$

NRMU

OPLAN

POL

$\mathrm{R}$

RNWY

ROK

ROKAF

$\mathrm{U}$ abundant

Air Base

Armed Forces Korea Network

Bird Aircraft Strike Hazard

Bird Hazard Working Group

building

common

Civil Engineer

centimeter(s)

Environmental Governing Standards

Fighter Wing

hectare(s)

hours

Integrated Natural Resources Management Plan

Korean Association for Conservation of Nature

Korean Airlines

kilometer(s)

meter(s)

Natural Resource Management Unit

Operations Plan

Petroleum oil and lubricants

rare

runway

Republic of Korea

Republic of Korea Air Force

uncommon 
This Page

Intentionally

Blank 


\section{AVIAN FIELD GUIDE AND CHECKLIST \\ for \\ Kunsan Air Base, Korea}

James B. Levenson, Ph.D.

Environmental Science Division

Argonne National Laboratory

\section{Executive Summary}

This report summarizes the results of the avian surveys conducted at Kunsan Air Base (AB). This on-going survey is conducted to comply with requirements of the Environmental Governing Standards (EGS) for the Republic of Korea, the Integrated Natural Resources Management Plan (INRMP) for Kunsan AB, and the 8th Fighter Wing's Bird Aircraft Strike Hazard (BASH) Plan. One hundred sixteen bird species representing 34 families were identified and recorded. Seven species are designated as Cultural Property Monuments, and their protection is accorded by the Korean Ministry of Culture and Tourism. Six species appear on the Korean Association for Conservation of Nature's (KACN's) list of Reserved Wild Species and are protected by the Korean Ministry of Environment. Combined, only ten different species are Republic of Korea (ROK)protected because the Eurasian Spoonbill, Peregrine Falcon, and Eurasian Oystercatcher are listed by both agencies.

\section{Purpose and Authority}

The primary objective of the avian survey at Kunsan $\mathrm{AB}$ was to determine what species of birds are present on the airfield and their respective habitat requirements during the critical seasons of the year. This requirement is specified in Annex C.4.a.(1-4) of the 8th Fighter Wing BASH Plan (8 FW OPLAN 91-202). The second objective was to initiate surveys to determine what bird species are present on Kunsan $\mathrm{AB}$ throughout the year, and from the survey results determine if threatened, endangered, or other Korean-listed bird species are present on Kunsan AB. This overall census satisfies Criterion 13-3.e of the EGS for Korea. The final objective was to formulate management strategies within Kunsan AB's operational requirements to protect and enhance habitats of known threatened, endangered, and ROK-protected species in accordance with EGS Criterion 13-3.a and also that are favorable for the reproduction of indigenous species in accordance with the EGS Criterion13-3.h.

\section{Study Area}

Kunsan AB is located on the west coast of the Korean Peninsula in Okku County, Chollabuk-Do Province. The base is eight miles southwest of Kunsan City and about 160 miles south of Seoul. Kunsan AB occupies 2,557 acres of a peninsula along the eastern shore of the Yellow Sea. The southern boundary of the base is an estuary formed by the confluence of the Mangyeung and Dongjin Rivers with the Yellow Sea. In Korea, this coastline and estuarine complex is known collectively as the Saemangeum Wetland and is the most dominant natural feature and habitat type associated with Kunsan AB.

The Yellow Sea is a semi-enclosed shallow sea located between the Korean Peninsula on the east and China to the north and west. The Yellow Sea is located in the East Asian-Australian Flyway, one of eight shorebird flyways around the world, stretching from Alaska and Siberia southward through east and southeastern Asia to New Zealand and Australia. It supports over 7 million shorebirds of which some 5 million are migratory. The coastal areas of the Yellow Sea provide key migration staging sites for many shore bird species and also 
support important concentrations of some species during the non-breeding season. It is estimated that a minimum of 2 million shorebirds ( $40 \%$ of the estimated flyway population) use the Yellow Sea wetlands during the northern migration and perhaps 1 million shorebirds pass through the region on southward migration (Barter, 2002).

The Yellow Sea contains more than 1 million hectares (ha) of tidal flats (Moores and Moores, 2003). According to Barter (2002), the Saemangeum Wetland forms the single most important migratory water bird site on the Yellow Sea. The Saemangeum Wetland comprises some 30,000 ha of tidal flats and 10,000 ha of shallows (Moores and Moores, 2003). It is known to support over 100,000 shorebirds at peak times and many more through the year. A total of 30 species of migratory waterbirds are found in the Saemangeum Wetland in internationally important concentrations (Moores, 2002). Internationally important concentrations (defined in accordance with the Ramsar Convention) are either $1 \%$ or more of a known population of a species or 20,000 or more individuals supported regularly at a site.

Today, the Saemangeum Wetland is the site of the world's largest ongoing coastal wetland reclamation project. The reclamation project was started in 1991 and involves the construction of a $33 \mathrm{~km}$-long seawall. At the time of this writing, approximately 29 of the $33 \mathrm{~km}$-long seawall has been completed. The completion of the seawall will seal off the entire Saemangeum Wetland (40,1000 ha, or $\left.401 \mathrm{~km}^{2}\right)$ and effectively result in the relocation of the Yellow Sea's coastline some $5 \mathrm{~km}$ west of Kunsan AB. Immediate effects will be (1) the loss of a significant marine breeding grounds for fish and shellfish, (2) the commensurate loss of the local commercial fisheries, (3) potentially significant declines in many resident and migratory waterbird populations (Moores and Moores, 2003), and (4) local meteorological changes for Kunsan AB.

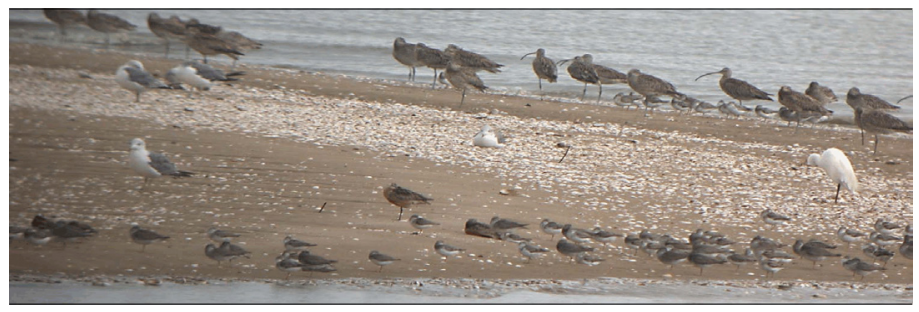

Intertidal zone at high tide

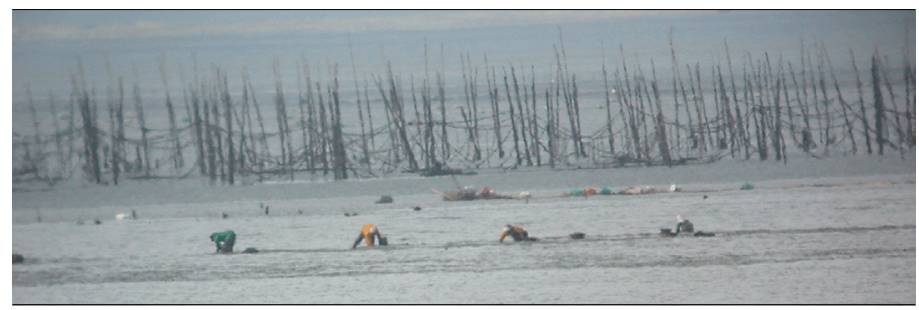

Intertidal zone at low tide 
For this study, the Saemangeum Wetland is referred to as the intertidal zone and lies between the sea wall and the tide line of the Yellow Sea along the southern and western boundaries of the base. This is the largest habitat type and fluctuates with the tides from a broad mudflat several miles in width to a shallow marine environment. Associated with this habitat type are rocky coastlines at the foot of Little and Big Coyote Hills and extensive shell bars that parallel the western edge of the base, offshore.

The other habitat types of Kunsan AB are classified as forest, wetland, airfield, and cantonment area. Little forest exists on Kunsan AB, consisting largely of mixed woodlots of pine and deciduous trees in the POLnorth area. The overstory is primarily composed of two species of pine, Japanese black pine (Pinus thunbergii) and Japanese red pine (Pinus densiflora), in fairly equal distribution. These pines are remnants of pine plantations likely established during the Japanese occupation. A small number of black locusts (Robinia pseudo-acacia) have emerged into the canopy layer, primarily in the northeastern portion of the unit.

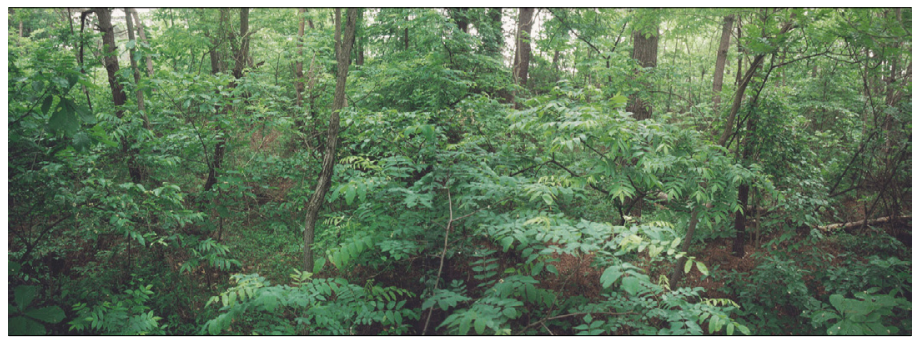

Examples of forest habitats found in the POL-north area

The sub-canopy layer is quite diverse and includes many native species with the potential to become the future canopy layer. Black locust and Platycarya (Platycarya strobilacea) are the most common understory species and range in height from 3 to $5 \mathrm{~m}$. Other native species present, all reaching to 5 meters, are Oriental white oak (Quercus aliena), Mongolian oak (Quercus mongolica), Japanese green alder (Alnus firma), and sumac (Rhus sp.). Adjacent to POL-north is Wolf Pack Park, which has a small stand of pine. Collectively, these two areas represent the forests of Kunsan AB.

Widely scattered and isolated wetland communities exist on Kunsan AB. Collectively, the wetland type includes the drainage ditches that occur on the airfield and golf course, and lead from the asbestos landfill area. Other wetland habitats occur on the airfield in water-filled ruts created by heavy mowing equipment. A true wetland exits along and at the terminus of a drainage ditch in the Civil Engineer's (CE's) bulk storage yard. No longer existing, a small wet area was located adjacent to the north and east edges of the land farm.

The airfield habitat includes the grassy area that lies between the active runway and the seawall along the western edge of the airfield, the southern overrun area to the seawall, and the grassy area between the eastern edge of the overrun area and Little Coyote Hill, including the asbestos landfill. Areas east of the active runway and the flight line area were not surveyed. 


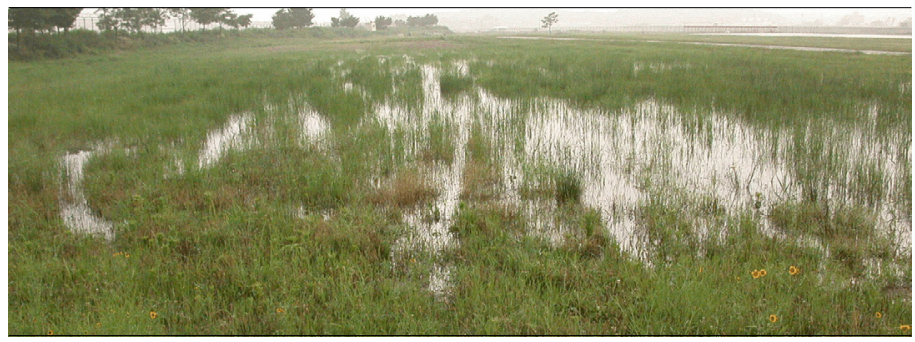

Example of a wetland adjacent to the airfield

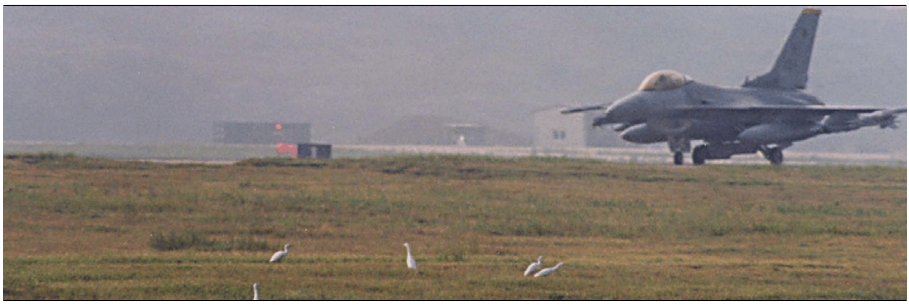

Example of shortly cropped airfield habitat

The cantonment area includes the remainder of the base including the community center, golf course, housing areas, and operational areas. Collectively, these areas are not unlike any urban environment and can be characterized as buildings surrounded by lawns and urban landscaping separated by roadways and parking areas.

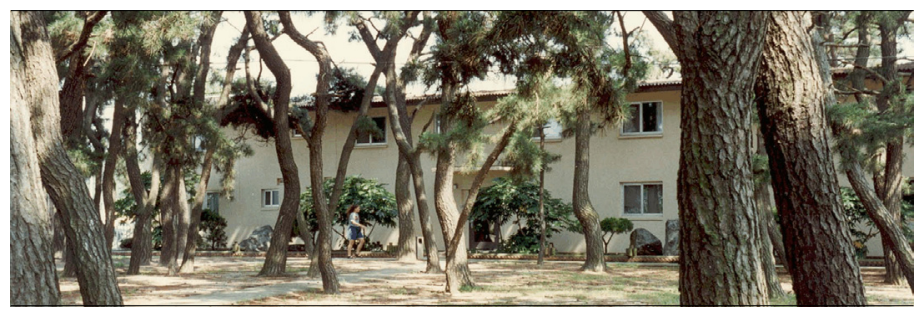

Example of urban habitat within the cantonment area 


\section{Methods}

The birds were recorded during the formal avian surveys conducted in 1999, 2000, 2001, and 2002. Subsequent and ongoing ecological monitoring surveys were conducted in 2003 (June, November), 2004 (February, June, November), and 2005 (May, August). Each survey was conducted over a three-day period. Two survey techniques were used to accomplish the objectives of these surveys, and were largely in accordance with the survey methods found in the Handbook of Field Methods for Monitoring Landbirds (Ralph et al., 1993) except as noted.

\begin{tabular}{|l|c|c|c|c|c|c|c|c|c|c|c|c|}
\hline & Jan & Feb & Mar & Apr & May & Jun & Jul & Aug & Sep & Oct & Nov & Dec \\
\hline Formal Monthly Surveys & 2000 & 2002 & 2002 & 2001 & 2000 & 2002 & 2001 & 1999 & 2002 & 2001 & 1999 & 2000 \\
\hline Ecological Monitoring & & 2004 & & & 2005 & $\begin{array}{c}2003 \\
2004\end{array}$ & & 2005 & & & $\begin{array}{c}2003 \\
2004\end{array}$ & \\
\hline
\end{tabular}

A modified strip transect was used for the airfield and along the runway. The transect, depicted by the red line in Figure 1, began near the northern edge of the airfield at the junction of the KAL (Korean Air Lines) taxiway with the north Perimeter Road. From there, crossing the runway (RNWY) 18 approach, the transect followed the Perimeter Road southward around the airfield, crossing the RNWY 36 approach, and ended at the intersection with Avenue B just south of the ROK Air Force (ROKAF) alert tree. The transect is 3.1 miles $(5.0 \mathrm{~km})$ long. Driving surveys along the transect were complemented with short walks into the infield and visits to seven predetermined observation points. The purpose of the short walks was to flush ground birds from their grassy cover. The seven observation points are located as follows:

1. Near Facility 6039, extreme north end of airfield;

2. Near Facility 3164 , almost directly across from Taxiway D;

3. Near Facility 1705 , almost directly across from Taxiway B;

4. Near the "Hot Pad," Facility 3094;

5. At the base of Big Coyote Hill;

6. At the fence east of the RNWY 36 approach; and

7. At the base of Little Coyote, east of Bldg. 5073.

Except for observation point 7, the points were selected for the vantage point they provided for examination of shore and wading birds along the Yellow Sea coastline. Each lap of the transect was paced to take no less than 1 hour and no more than 1.5 hours. Other data recorded for each transect lap included the time of day, weather conditions, tide level, and any other significant factor.

Area surveys were employed to investigate the birds of the Natural Resource Management Units (NRMUs) described and mapped in Appendix B of Kunsan AB's Integrated Natural Resources Management Plan (INRMP). For these surveys, birds were observed at specific locations. This technique is especially effective in determining relative abundance, habitat relationships, and discovering rare species (Ralph et al., 1993). For the fuel storage area or POL-north area (Fig. 1), the survey encompassed a series of five adjacent point surveys. Each point survey was approximately 20 minutes in duration for up to a total of two hours per day. Birds in the wooded areas were extremely wary, and to observe them, one was required to observe patiently from a single point with limited activity between points. Two points were established in the two separate segments of a semi-improved stand of pines (Pinus thunbergii and $P$. densiflora). A third point was established in an area also forested with pines. The final two points were located within a mixed stand of black locust (Robinia pseudo-acacia) and pines. 


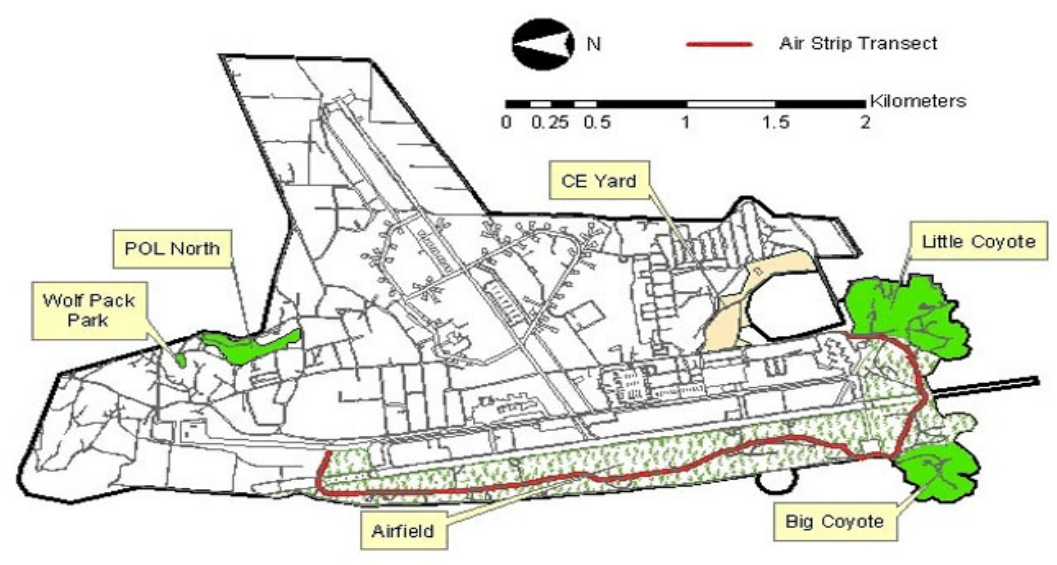

Figure 1. Bird survey areas of Kunsan Air Base

A single survey point was established in Wolf Pack Park (Fig. 1). Surveys of Little Coyote Hill were conducted when access was possible. The surveys of Little Coyote Hill combined walking line transects along the main road and trails supplemented with point surveys near the two hill crests. Access restrictions to Big Coyote Hill precluded avian surveys, but the habitats of Big Coyote Hill likely support an avifauna similar to Little Coyote Hill and the POL-north area. Most areas within the cantonment area were surveyed including the billeting area, golf course, organizational compounds, and other common areas. ROKAF and restricted areas were omitted.

The best time to conduct avian surveys is usually between 0500 and $0900 \mathrm{hrs}$ in most temperate latitudes during the breeding season and under most circumstances; no counts should be done after 1000 hrs (Ralph et al., 1993). For our objectives, this restriction was ignored because bird activity in the vicinity of the airfield is an issue throughout the day. The survey protocol used was to start within 15 minutes of the local sunrise and continue through the ensuing four hours. Bird activity, especially for woodpeckers, ducks, rooks, night herons, and owls, was observed to increase again about two hours before the local sunset. During this period, survey effort was limited to the airfield transect, disregarding the cantonment and wooded areas.

Surveys were performed under all weather conditions to ensure observation of species such as waterfowl and shorebirds, which may be active during inclement weather. Primarily recommended for monitoring land birds, Ralph et al. (1993) suggest that birds should not be surveyed when rain or wind interferes with the audibility of bird calls, when fog and drizzle interfere with visibility, or when cold weather dampens overall activity. At Kunsan, dense early morning fog was common during the spring and fall, severely restricting visibility. Nonetheless, important information regarding the activity of birds in the vicinity of the airfield was recorded. 
Sometimes during the performance of other projects, a new bird species would be encountered on the base. When a bird species was observed other than during the formal surveys anywhere on Kunsan AB, it was recorded as an "incidental sighting" by species, number of individuals, date, and location. An example includes the Eurasian Woodcock recorded by Peter Nebel on page 35.

\section{Species Accounts}

A total of 116 species representing 34 families was recorded during the formal surveys on Kunsan $\mathrm{AB}$ and the adjoining shoreline of the Yellow Sea. The order of presentation of the species follows Lee et al. (2000) A Field Guide to the Birds of Korea. For each species encountered, an individual species account provides the English common name, the genus and species, and the Korean common name, in accordance with Lee et al. (2000). English common names also follow Lee et al. (2000). However, I have adopted Kaufman's (1997) convention of capitalizing common names. He and other ornithologists find that capitalizing the common names clarifies discussions of the nearly 10,000 species of birds in the world. For example, several species of kingfishers are common around the world, but there is only one Common Kingfisher (Alcedo atthis). Many flycatchers are grey-spotted, but there is only one Grey-spotted Flycatcher (Muscicapa griseisticta).

Following the names, a photograph of each bird species is provided for all but 11 species. At the outset of this survey, the intent was to document the presence of each species with a photograph from the base when possible. In many cases, the quality of the photographs suffers from the less than optimal photographic conditions. For example, birds on the mudflats were often too distant to capture a quality photograph. This was especially true when attempting to take photographs through the chain-link perimeter fence or across a few hundred meters of mudflats distorted by the shimmer of heat currents. Invariably it seemed that the lighting or direction of exposure was less than desirable. In many areas of Kunsan AB, the opportunity for photographic documentation was either prohibited or not appropriate, and thus was not attempted. This was true for restricted areas, areas around the ROKAF facilities, and along the flightline. Base personnel would regularly challenge the authorization of a photographer equipped with cameras, binoculars, and spotting scope in the field. Finally, the general human activity level on base encourages birds to keep moving. Despite these impediments, photographs sufficient for identification were acquired for approximately $90 \%$ of the species recorded on base.

Beneath each photograph, a matrix is provided indicating the month(s) of the year, relative abundance, and habitat type for each species encountered. Abbreviations for terms of relative abundance follow the terminology of Massey et al. (1982) in A Field Guide to the Birds of Japan. The terms include:

A - (Abundant) An abundant bird may be seen in large numbers every time one visits the proper habitat during the proper season.

C - (Common) A common bird will probably be found most of the time in the right habitat and season, but perhaps in smaller numbers.

$\mathrm{U}$ - (Uncommon) An uncommon bird will likely be found only in small numbers, although it may occur regularly.

$\mathrm{R}$ - (Rare) A rare bird is, by definition, hard to find. It may occur in highly specific or very limited habitats. 
Following each data matrix, an underlined statement of the status of each bird in Korea according to Lee et al. (2000) is provided. Following that statement is a second statement of the species' status on Kunsan AB based on the results of the monthly avian surveys and the follow-on ecological monitoring effort.

Ten species are protected by law in the Republic of Korea. They include members of five families: (1) Oystercatchers (Haematopodidae), (2) Sandpipers (Scolopacidae), (3) Spoonbills (Threskiornithidae), (4) Hawks (Accipitridae), and (5) Barn owls (Tytonidae).

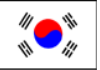

If the species is listed by either the Korean Ministry of Environment as "Rare," "Threatened," or "Reserved,"or by the Ministry of Culture and Tourism as a "Cultural Property," the Korean flag and the designation(s) are provided.

Haematopodidae (1 species): The Oystercatcher (Haematopus ostralegus) appears to be a year-round resident at Kunsan AB. Initially, a single pair was observed along the rocky shoreline at the base of Big Coyote Hill on May 20, 1998. Several pairs were observed on February 25 and 26 and June 22 and 23, 2002. The June presence suggests that the Oystercatcher nests in the vicinity of Kunsan. Over 100 individuals were observed on the shell bar beyond Big Coyote Hill on September 24 and 25, 2002. Several individuals were observed on November 7, 2004.

Scolopacidae (1 species): The Australian Curlew (Numenius madagascariensis) is considered endangered through out the world. It is significant that this species was sighted along the Kunsan AB shoreline during nine of the 12 months surveyed. As this species breeds and nests in the Arctic, it is presumed that some of the birds are migrants, others are winter residents, and still others are juveniles too young to breed.

Threskiornithidae (1 species): The Eurasian Spoonbill (Platalea leucorodia) is uncommon along the shoreline beneath Big Coyote Hill. It was recorded on September 25, 2002, November 7, 2003, and February 22, 2004. Although not recorded on base, 2-4 Black-faced Spoonbills (Platalea minor) are sometimes observed immediately east of the base on the mudflats south of the former Okku saltpans.

Accipitridae (6 species): The Eurasian Kestrel (Falco tinnunculus) is a common, year-round resident of Kunsan AB and was sighted during each survey period. The Chinese Sparrowhawk (Accipiter soloensis) was sighted during the November (1999) and July (2001) avian surveys. It is a secretive bird and is likely present during much of the warm weather season. A dead specimen of the less-common Eurasian Sparrowhawk (Accipiter nisus) was observed at the corner of 10th Street \& Avenue C on March 24, 2002. A living specimen was observed in the north POL area on September 24, 2002. The Common Buzzard (Buteo buteo) is sometimes observed soaring above the base during the winter months. There is no evidence to date to suggest that it lands or resides on base. The Eurasian Hobby (Falco subbuteo) was first observed in the pines near the KAL taxiway on September 23-25,2002. It was also recorded in June 2003 and August 2005, base wide. Finally, a Peregrine Falcon (Falco peregrinus) was first observed on February 24, 2002, eating a fish on the beach just north of Big Coyote Hill and then again in February 2004.

Tytonidae (1 species): A pair of Brown Hawk Owls (Ninox scutulata) was observed in the north POL area (NRMU POL-3) on May 3, 2000, during the avian survey. It was first assumed they were migrating. But the presence of the owl on June 24, 2002, suggests they reside and potentially nest on or near Kunsan AB. More recent sightings (May 2005) suggest that the owl may actually nest in the POL-north area. 


\section{Great Cormorant}

Phalacrocorax carbo

\section{Minmulgamauji}

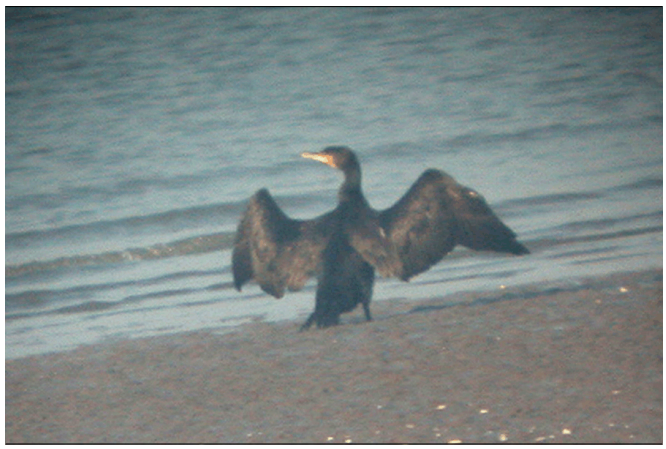

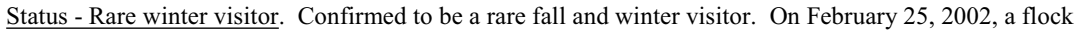
of 5 Great Cormorants was sighted along the base of Big Coyote Hill. During ecological monitoring surveys on October 31, 2003, and again in February 2004, a larger flock of 11 birds was sighted in the same location.

\begin{tabular}{|l|l|l|l|l|l|l|l|l|l|l|l|l|}
\hline \multicolumn{10}{|c|}{ Great Cormorant } \\
\hline & Jan & Feb & M ar & Apr & May & Jun & Jul & Aug & Sep & Oct & Nov & Dec \\
\hline Forests & & & & & & & & & & & & \\
\hline Wetlands & & & & & & & & & & & & \\
\hline Intertidal Zone & & R & & & & & & & & R & & \\
\hline Airfield & & & & & & & & & & & & \\
\hline Cantonment & & & & & & & & & & & & \\
\hline
\end{tabular}

As a group, cormorants characteristically perch with their wings outstretched, as shown above. They usually fly low over water with their necks outstretched somewhat lower than their bodies. Cormorants are diving birds and feed on small fish they chase and capture during dives. They are colonial breeders on cliffs or inland in trees and may be year-round residents in the Kunsan area.

The Great Cormorant is a large bird reaching $82 \mathrm{~cm}$ in length with a wing span of $1.3 \mathrm{~m}$. Predominantly black, cormorants have webbed feet, short stiff tails, long necks, and slender, hooked bills. Field marks for the Great Cormorant include a brownish iridescence on the back and naked yellow skin on the face. 


\section{Black-crowned Night Heron}

Nycticorax nycticorax

\section{Hae-oragi}

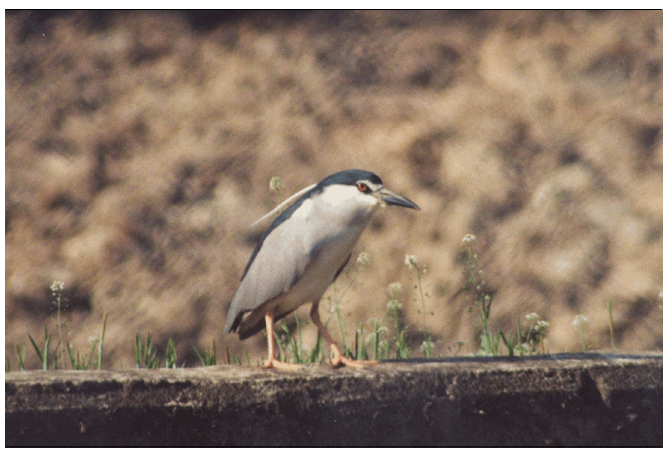

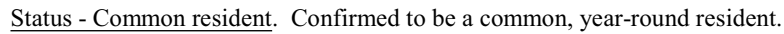

\begin{tabular}{|l|c|c|c|c|c|c|c|c|c|c|c|c|}
\hline \multicolumn{10}{|c|}{ Black-crowned Night Heron } \\
\hline & Jan & Feb & Mar & Apr & M ay & Jun & Jul & Aug & Sep & oct & Nov & Dec \\
\hline Forests & C & C & C & & & C & & & C & C & C & C \\
\hline Wetlands & & & & & C & & & C & & & C & \\
\hline Intertidal Zone & & & & & & & & & & & & \\
\hline Airfield & & C & & C & & C & & & C & & C & U \\
\hline Cantonment & & & & & & & R & C & R & & & \\
\hline
\end{tabular}

Night herons are so named because of their tendency to be most active during the darkness hours and crepuscular periods of dawn and dusk. The Black-crowned Night Heron commonly visits the drainage ditches on the airfield and the golf course. At those locations, they stalk their primary prey: fish, insects, and amphibians. In the winter, a flock of night herons roosts in the pine grove along Beacon Avenue inside the POL-north area. In the spring, several pairs nest on Little Coyote Hill.

Black-crowned Night Herons are stocky, medium-sized birds reaching about $58 \mathrm{~cm}$ in length. Their head, bill, and back are black. The wings are grey, the underparts are white, and the legs are yellow. Field marks are long white plumes on the head in the summer. Most striking is their large red eyes that turn from yellow during their first winter. 


\section{Striated Heron}

Butorides striatus

\section{Geomeudaenggihae-oragi}

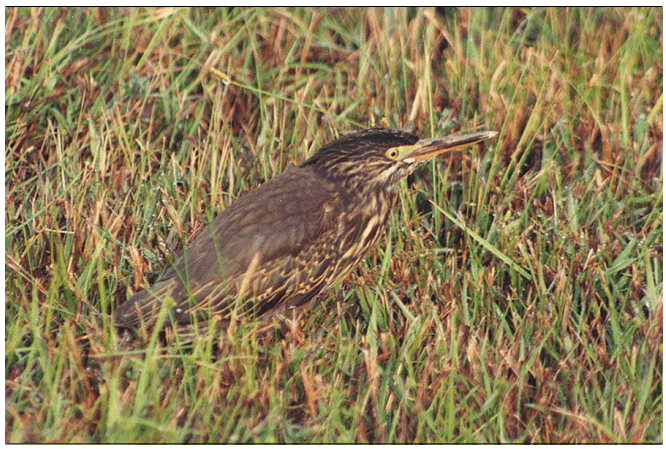

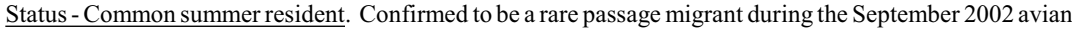
survey.

\begin{tabular}{|l|l|l|l|l|l|l|l|l|l|l|l|l|}
\hline \multicolumn{10}{|c|}{ Striated Heron } \\
\hline & Jan & Feb & Mar & Apr & M ay & Jun & Jul & Aug & Sep & Oct & Nov & Dec \\
\hline Forests & & & & & & & & & & & & \\
\hline Wetlands & & & & & & & & & R & & & \\
\hline Intertidal Zone & & & & & & & & & & & & \\
\hline Airfield & & & & & & & & & R & & & \\
\hline Cantonment & & & & & & & & & R & & & \\
\hline
\end{tabular}

Usually solitary, a few Striated Herons were seen in the drainage ditches along the western edge of the golf course and between the Perimeter Road and seawall in September 2002. They can be found in a variety of wetland habitats, but prefer streams, ponds, and marshes with nearby woodland cover. They often perch in trees.

The Striated Heron is a chunky, medium-sized bird reaching approximately $52 \mathrm{~cm}$ in length and is smaller than the Black-crowned Night Heron. The head and bill are black and the upper parts and wings are greenishgrey. The wing feathers are bordered with white. The underparts are generally grey and the legs are yellow. Striated Herons lack the plumes and red eyes typical of the Black-crowned Night Heron. The individual pictured above is an immature bird and does not display the adult plumage. 


\section{Cattle Egret \\ Bubulcus ibis}

\section{Hwangno}

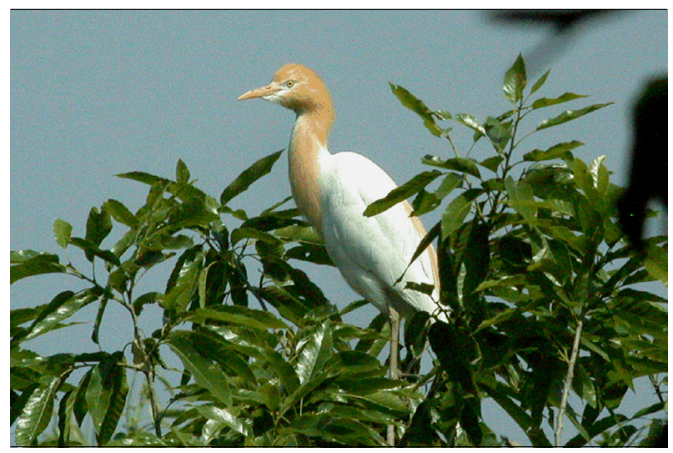

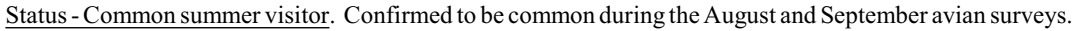

\begin{tabular}{|l|l|l|l|l|l|l|l|l|l|l|l|l|}
\hline \multicolumn{10}{|c|}{ Cattle Egret } \\
\hline & Jan & Feb & M ar & Apr & M ay & Jun & Jul & Aug & Sep & Oct & Nov & Dec \\
\hline Forests & & & & & & & & & & & & \\
\hline Wetlands & & & & & & & & & & & & \\
\hline Intertidal Zone & & & & & & & & & & & & \\
\hline Airfield & & & & & & & & A & C & & R & \\
\hline Cantonment & & & & & & & & C & C & & & \\
\hline
\end{tabular}

From the mid-fall until spring, the Cattle Egret is largely absent from the Kunsan area. In the spring, it returns to nest and raise its young. Though the Cattle Egret is considered a common summer visitor, it is generally not seen on the airfield until late summer just prior to migration. From August through September, large flocks of 60 to 100 birds commonly forage on the airfield. By the time the Cattle Egrets appear on the airfield, the males have lost much of the chestnut breeding coloration on their heads, necks, and backs and appear totally white.

Cattle Egrets tend to flock, whereas the other white egrets (Great, Intermediate, and Little Egrets) do not. Also, Cattle Egrets prefer open grassy areas, while the other egrets prefer wetland habitats.

Field marks of the Cattle Egret include a small $(50 \mathrm{~cm})$ stature, short yellow bill, and pale yellow facial skin. 


\section{Great Egret \\ Ardea alba (formerly Egretta alba)}

\section{Jungdaebaengno}

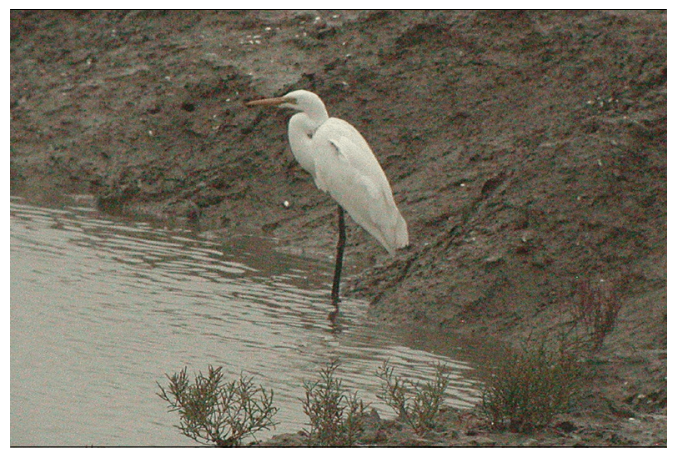

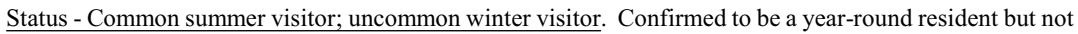
recorded on base in January, April, or May.

\begin{tabular}{|l|c|c|c|c|c|c|c|c|c|c|c|c|}
\hline \multicolumn{10}{|c|}{ Great Egret } \\
\hline & Jan & Feb & M ar & Apr & M ay & Jun & Jul & Aug & Sep & Oct & Nov & Dec \\
\hline Forests & & & & & & & & & & & & \\
\hline Wetlands & & & & & & & & & & & & U \\
\hline Intertidal Zone & & C & & & & C & C & U & C & & U & U \\
\hline Airfield & & & U & & & U & & U & C & U & & C \\
\hline Cantonment & & & & & & & & & & & & \\
\hline
\end{tabular}

During the spring, the Great Egret apparently spends much time near the rookery sites. When the young are fledged, they seem to remain near the inland rice paddies and irrigation ditches through mid-summer. One or two Great Egrets are sometimes present near the airfield drainage ditches. But in the fall and early spring, several Great Egrets can be observed on the tidal flats and shoals at any given time.

The Great Egret is very similar to the Intermediate Egret in appearance, except larger. The Great Egret reaches approximately $90 \mathrm{~cm}$ in length with a wing span of $1.6 \mathrm{~m}$. During the breeding season, the Great Egret's bill is black (turning yellow during the non-breeding season) and the facial skin is a bright blue-green. Other distinguishing field marks include (1) a longer bill, (2) a gape extending beyond the eye, (3) plumes on the lower back, and (4) greyish tibia. 


\section{Intermediate Egret}

Egretta intermedia

\section{Jungbaengno}

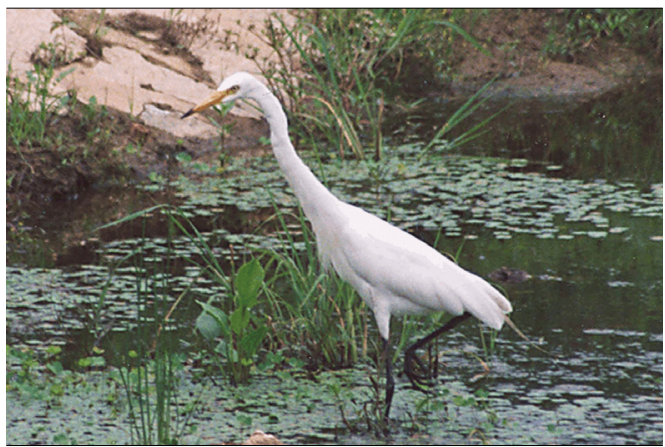

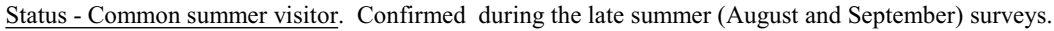

\begin{tabular}{|l|c|c|c|c|c|c|c|c|c|c|c|c|}
\hline \multicolumn{10}{|c|}{ Intermediate Egret } \\
\hline & Jan & Feb & M ar & Apr & M ay & Jun & Jul & Aug & Sep & Oct & Nov & Dec \\
\hline Forests & & & & & & & & & & & & \\
\hline Wetlands & & & & & & & & & U & & & \\
\hline Intertidal Zone & & & & & & & & U & U & & & \\
\hline Airfield & & & & & & & & & & & & \\
\hline Cantonment & & & & & & & & & & & & \\
\hline
\end{tabular}

The Intermediate Egret is a summer visitor and breeds in the vicinity of Kunsan. However, they prefer freshwater ecosystems and apparently reside near rice paddies and rivers rather than along the coast of the Yellow Sea. Although present in the Kunsan area from early spring, they do not become apparent on the airfield until late summer.

The Intermediate Egret is very similar to the Great Egret in appearance, except smaller. The Intermediate Egret reaches approximately $68 \mathrm{~cm}$ in length. During the breeding season, the Intermediate Egret's bill is also black turning to mostly yellow with a black tip during the non-breeding season. Other distinguishing field marks include (1) a shorter bill, (2) a gape not extending beyond the eye giving it a 'puffy-cheeked' look, (3) plumes on the upper breast and lower back, and (4) black tibia. 


\section{Little Egret \\ Egretta garzetta}

\section{Soebaengno}

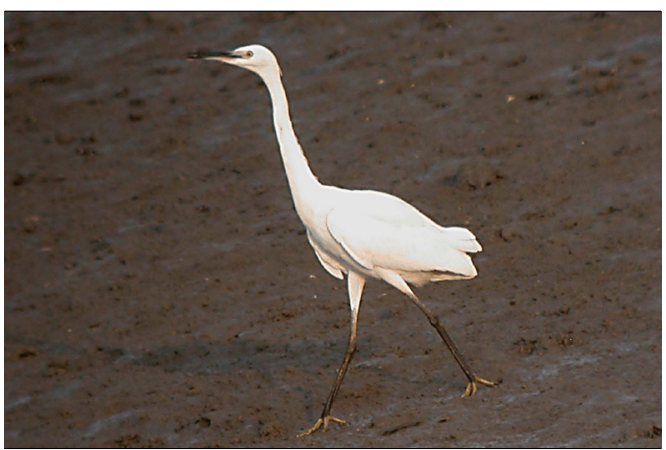

Status - Summer visitor and locally common resident. Confirmed to be a common summer visitor.

\begin{tabular}{|l|l|l|l|l|l|l|l|l|l|l|l|l|}
\hline \multicolumn{10}{|c|}{ Little Egret } \\
\hline & Jan & Feb & M ar & Apr & M ay & Jun & Jul & Aug & Sep & Oct & Nov & Dec \\
\hline Forests & & & & & & & & & & & & \\
\hline Wetlands & & & & & & & & U & & & & \\
\hline Intertidal Zone & & & & & & & U & C & & & C & \\
\hline Airfield & & & & & & & & U & C & U & & \\
\hline Cantonment & & & & & U & & & & & & & \\
\hline
\end{tabular}

The Little Egret occupies all kinds of wetlands but generally prefers freshwater systems including rice paddies and drainage ditches. However, it also occupies tidal mudflats, especially in the vicinity of Kunsan AB. The Little Egret tends to be a solitary feeder preying on crustaceans, fish, and insects.

The Little Egret stands approximately $60 \mathrm{~cm}$ tall. They are readily differentiated from the other egrets by their long black bill and conspicuous yellow feet. Their solitary behavior and black bill distinguish it from the Cattle Egret. 


\section{Grey Heron}

Ardea cinerea

\section{Waegari}

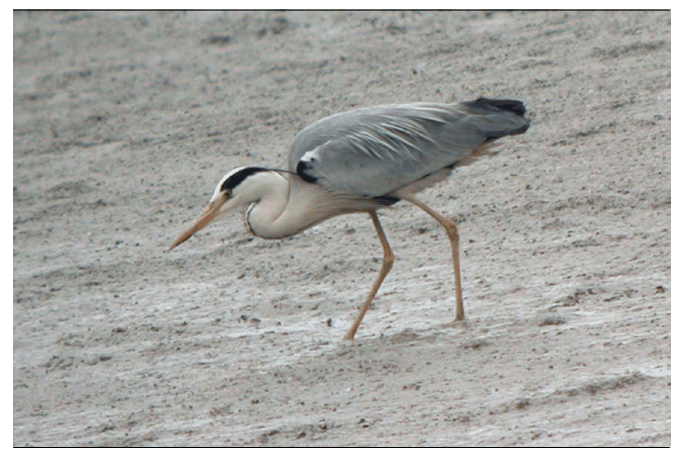

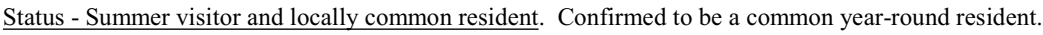

\begin{tabular}{|l|c|c|c|c|c|c|c|c|c|c|c|c|}
\hline \multicolumn{10}{|c|}{ Grey Heron } \\
\hline & Jan & Feb & M ar & Apr & M ay & Jun & Jul & Aug & Sep & oct & Nov & Dec \\
\hline Forests & & & & & & & C & & C & C & & \\
\hline Wetlands & & & U & & & U & & U & U & & & \\
\hline Intertidal Zone & C & C & C & C & C & C & C & C & C & C & C & c \\
\hline Airfield & C & C & C & C & U & A & C & C & C & C & C & c \\
\hline Cantonment & & & & & U & U & & & & & U & \\
\hline
\end{tabular}

The Grey Heron also occupies all types of wetlands. They can be observed in both salt and freshwater marshes, tidal flats, and along rivers. The Grey Heron was a very common inhabitant of the airfield drainage ditches until they were covered. They are still common on the mudflats near the tide line, but seldom venture beyond the Perimeter Road. They feed primarily on fish and frogs.

The Grey Heron is one of the largest birds in the Kunsan area standing approximately $95 \mathrm{~cm}$ tall. They are readily recognized by its tall stature, huge yellow bill, and long yellow legs. Females have more dull plumage than males. The adult male in the photograph above displays the typical grey wings and back with white neck and underparts accented with a black crown stripe and shoulder patch. 


\section{Eurasian Spoonbill \\ Platalea leucorodia}

Norangburijeo-eosae

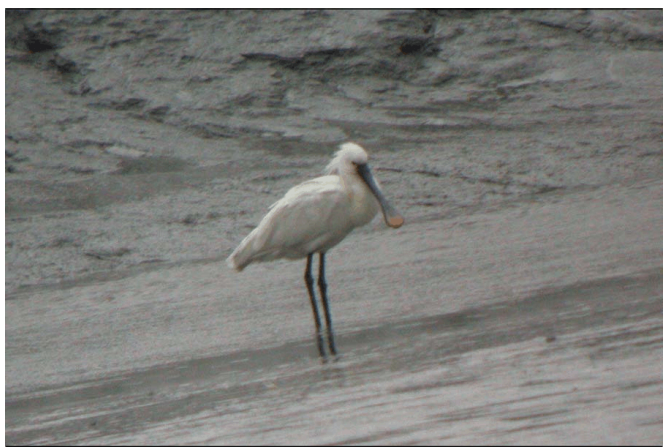

Status - Rare winter visitor. Confirmed to be an uncommon winter visitor along the shoreline beneath Big Coyote Hill. During the avian surveys, groups of 3 to 4 birds were recorded on September 25, 2002, November 7, 2003, and February 22, 2004.

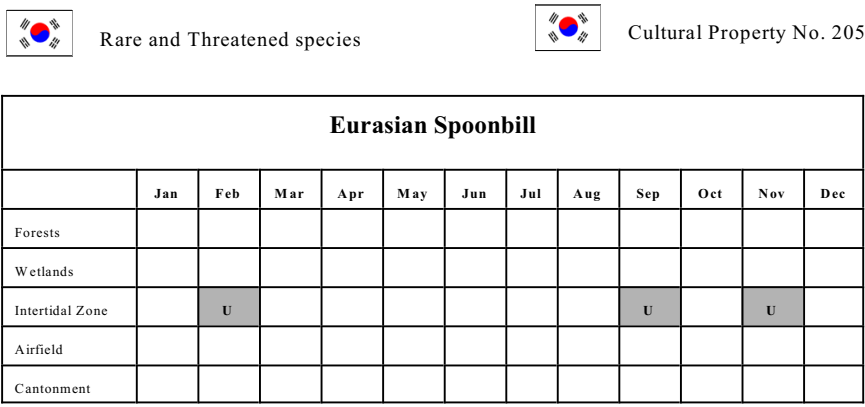

The Eurasian Spoonbill's preferred habitats are estuaries and mudflats, but they may also be seen in reservoirs and rice paddies. When feeding, spoonbills sweep their bills from side to side to capture prey.

The Eurasian Spoonbill is a tall, white, crested wading bird reaching $86 \mathrm{~cm}$ in length. East of Kunsan AB, the Eurasian Spoonbill has been observed with the smaller Black-faced Spoonbills (P. minor) on the mudflats south of the former Okku saltpans. The Eurasian can be differentiated from the Black-faced Spoonbill by the yellow tip on its otherwise black bill and a white feathered forehead instead of black facial skin. 


\section{Common Shelduck}

Tadorna cristata

\section{Wonangsachon}

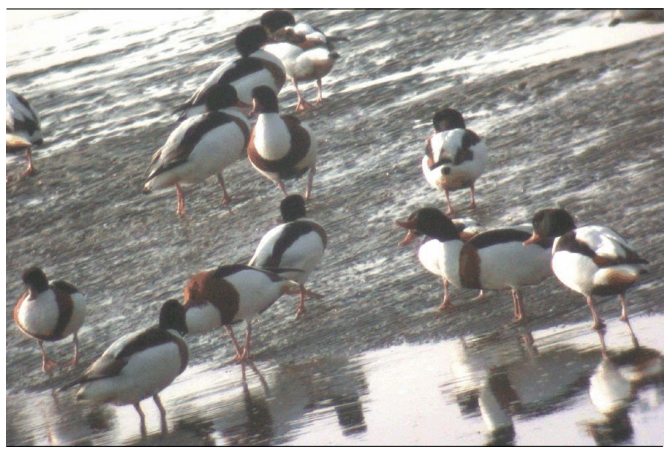

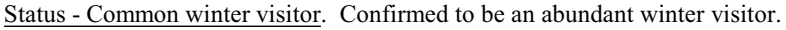

\begin{tabular}{|l|c|c|c|c|c|c|c|c|c|c|c|c|}
\hline \multicolumn{10}{|c|}{ Common Shelduck } \\
\hline & Jan & Feb & M ar & Apr & May & Jun & Jul & Aug & Sep & Oct & Nov & Dec \\
\hline Forests & & & & & & & & & & & & \\
\hline Wetlands & & & & & & & & & & & & \\
\hline Intertidal Zone & A & A & A & & & & & & & & & A \\
\hline Airfield & & & & & & & & & & & & \\
\hline Cantonment & & & & & & & & & & & & \\
\hline
\end{tabular}

The Common Shelduck breeds in Central Asia and moves to southern and eastern Asia during the nonbreeding season. Flocks of thousands of Common Shelducks occur along the Yellow Sea tide line immediately adjacent to the base during the winter months. Their preferred wintering habitats are mudflats and estuaries.

A relatively large duck, the Common Shelduck is about $63 \mathrm{~cm}$ long. They appear to be mostly white with a dark iridescent green head. A chestnut-colored band around the breast and black scapulars are good field marks, along with a reddish-orange bill and legs. 


\section{Northern Pintail}

Anas acuta

Gobang-ori

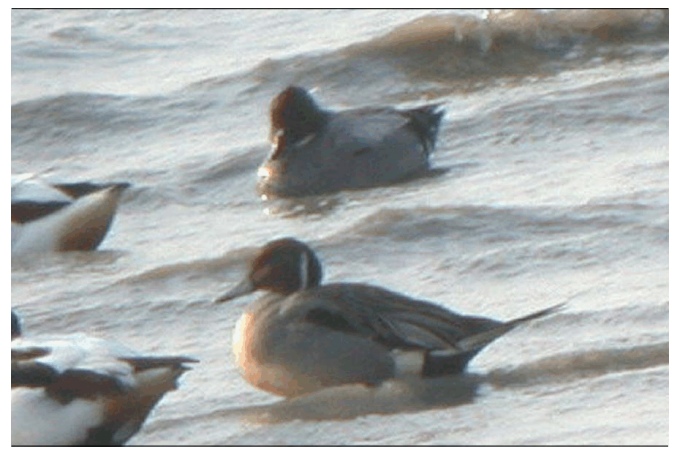

Status - Common winter visitor. Confirmed to be an uncommon winter visitor along the Yellow Sea shoreline. In the company of huge rafts of Common Shelducks, Spot-billed Ducks, and Mallards, the Northern Pintail is relatively uncommon.

\begin{tabular}{|l|l|l|l|l|l|l|l|l|l|l|l|l|}
\hline \multicolumn{10}{|c|}{ Northern Pintail } \\
\hline & Jan & Feb & M ar & Apr & M ay & Jun & Jul & Aug & Sep & Oct & Nov & Dec \\
\hline Forests & & & & & & & & & & & & \\
\hline Wetlands & & & & & & & & & & & & \\
\hline Intertidal Zone & & U & & & & & & & & & & \\
\hline Airfield & & & & & & & & & & & & \\
\hline Cantonment & & & & & & & & & & & & \\
\hline
\end{tabular}

The Northern Pintail prefers freshwater systems and is more typical of lakes, marshes, and rivers. They often graze in rice paddies. The Pintail breeds in northern Asian and North America. The Northern Pintail is the same species that occurs in the United States.

A large duck, the male Northern Pintail is about $75 \mathrm{~cm}$ long and the female about $53 \mathrm{~cm}$ long. The male Pintail is distinctive in appearance with its long graceful neck and characteristic "pin-shaped" tail. The female resembles other female marsh ducks - generally brown with dark brown markings. Field marks include a black bill with grey sides and a noticeably longer tail. 


\section{Eurasian Wigeon}

Anas penelope

\section{Hong-meoriori}

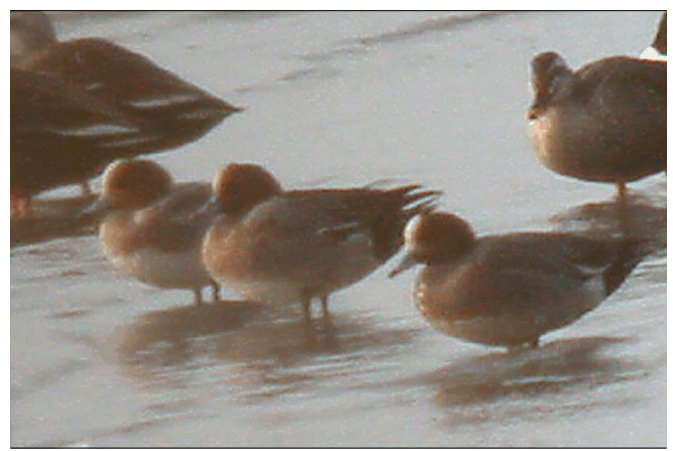

Status - Common winter visitor. Confirmed to be a common winter visitor along the Yellow Sea shoreline. In the company of huge rafts of Common Shelducks, Spot-billed Ducks, and Mallards, the Eurasian Wigeon is less common.

\begin{tabular}{|l|l|l|l|l|l|l|l|l|l|l|l|l|}
\hline \multicolumn{10}{|c|}{ Eurasian Wigeon } \\
\hline & Jan & Feb & M ar & Apr & M ay & Jun & Jul & Aug & Sep & oct & Nov & Dec \\
\hline Forests & & & & & & & & & & & & \\
\hline W etlands & & & & & & & & & & & & \\
\hline Intertidal Zone & & C & & & & & & & & & & \\
\hline Airfield & & & & & & & & & & & & \\
\hline Cantonment & & & & & & & & & & & & \\
\hline
\end{tabular}

The Eurasian Wigeon grazes on aquatic grasses and seaweeds. As such, they can be found in freshwater, estuaries, and saltwater systems. The Wigeon breeds throughout much of northern Asian and may breed in Korea. The Eurasian Wigeon is closely related to the American Wigeon (A. americana) that occurs in the United States.

The Eurasian Wigeon is a small, chunky-appearing duck. Both sexes are about $49 \mathrm{~cm}$ long. Field marks for the male include a chestnut-colored head with a yellow forehead and crown. The female is rusty brown in color and well camouflaged. Both sexes display a green speculum in flight. 


\section{Mallard \\ Anas platyrhynchos}

\section{Cheongdung-ori}

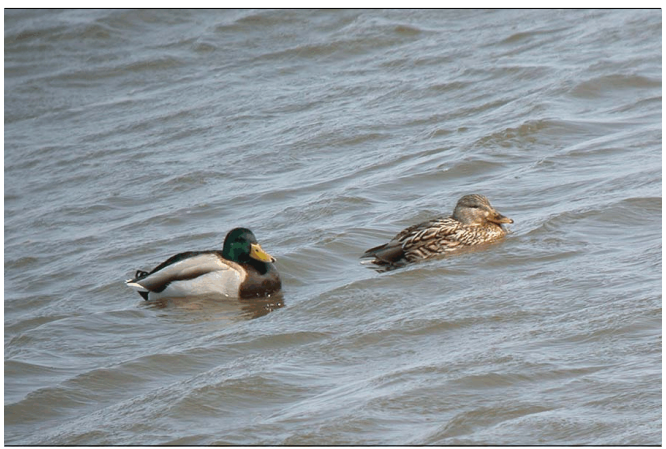

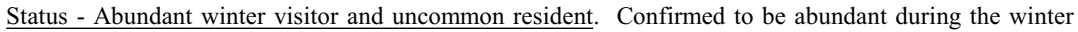
surveys.

\begin{tabular}{|l|c|c|c|c|c|c|c|c|c|c|c|c|}
\hline \multicolumn{10}{|c|}{ Mallard } \\
\hline & Jan & Feb & M ar & Apr & May & Jun & Jul & Aug & Sep & Oct & Nov & Dec \\
\hline Forests & & & & & & & & & & & & \\
\hline Wetlands & & & & & & & & & & & & \\
\hline Intertidal Zone & A & A & A & & & & & & U & A & A & A \\
\hline Airfield & & & & & & & & & & & & \\
\hline Cantonment & & & & & & & & & & & & \\
\hline
\end{tabular}

Worldwide, the Mallard is probably the most abundant duck species. The Mallard is the same species as found in the United States. Around Kunsan, the Mallard first becomes evident in early fall and becomes abundant during the winter months. Mallards form rafts of several hundred individuals along the tide line of the Yellow Sea, often in association with Spot-billed Ducks. By the end of March, only a few isolated individuals and pairs remain to breed. The majority migrate to north-central and northeastern Asia to breed.

The Mallard is a relatively large dabbling duck reaching approximately $60 \mathrm{~cm}$ in length. The males are recognized by their iridescent green heads, thin white collar, and chestnut-colored breast. The back and wings are grey and the underparts are white. The female is a mottled brown. Both sexes have orange legs and, in flight, display a blue speculum bordered with white. 


\section{Spot-billed Duck}

Anas poecilorhyncha

\section{Huinppyamgeodung-ori}

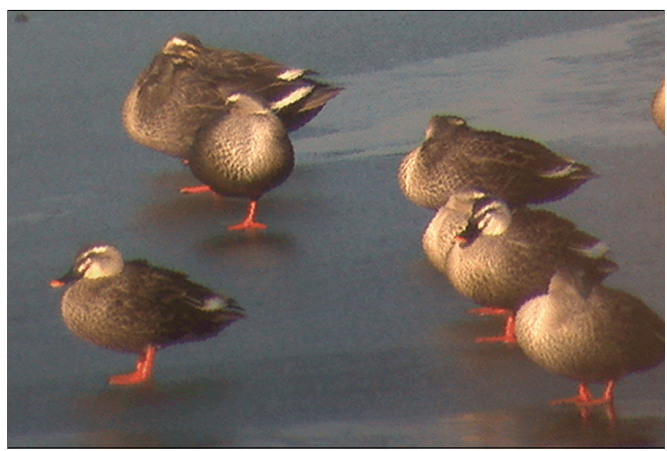

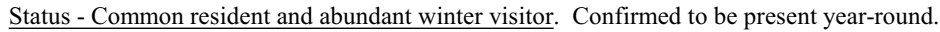

\begin{tabular}{|l|c|c|c|c|c|c|c|c|c|c|c|c|}
\hline \multicolumn{10}{|c|}{ Spot-billed Duck } \\
\hline & Jan & Feb & M ar & Apr & M ay & Jun & Jul & Aug & Sep & oct & Nov & Dec \\
\hline Forests & & & & & & & & & & & & \\
\hline Wetlands & & & & & & & & & & & & \\
\hline Intertidal Zone & A & C & A & & & C & U & & & C & A & C \\
\hline Airfield & & U & & & C & C & & U & & C & & \\
\hline Cantonment & & & & & & & & & U & & & \\
\hline
\end{tabular}

The Spot-billed Duck is the most common duck in the vicinity of the base, year-round. They form huge rafts along the tide line during the winter months. As spring approaches, they decline in numbers and eventually appear as pairs and family units by early summer. They occupy almost any aquatic habitat. Once common in the airfield drainage ditches, they are now restricted to the area between Perimeter Road and the tide line on base. During the monsoon season, they dabble in water-filled tire ruts and associated wetlands on the airfield.

Slightly larger and heavier-bodied than Mallards, the males and females share similar mottled brown plumage. The diagnostic field marks are bold whitish eyebrow above a dark stripe through the eye. Both sexes have yellow-tipped black bill, orange legs, and display a blue speculum when in flight. 


\section{Common Teal}

Anas crecca

\section{Soe-ori}

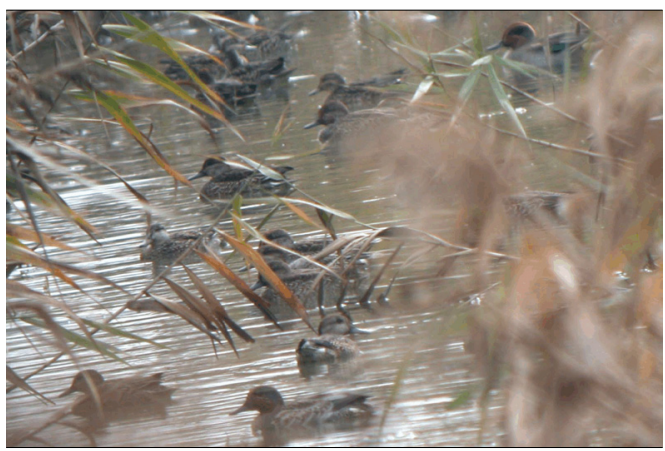

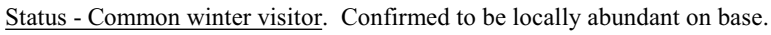

\begin{tabular}{|l|c|c|c|c|c|c|c|c|c|c|c|c|}
\hline \multicolumn{10}{|c|}{ Common Teal } \\
\hline & Jan & Feb & Mar & Apr & May & Jun & Jul & Aug & Sep & Oct & Nov & Dec \\
\hline Forests & & & & & & & & & & & & \\
\hline Wetlands & & & & & & & & & & & A & \\
\hline Intertidal Zone & & & & & & & & & & & & \\
\hline Airfield & & & & & & & & & & & & \\
\hline Cantonment & & & & & & & & & & & & \\
\hline
\end{tabular}

Common Teal prefer freshwater habitats with dense shoreline vegetation. Although relatively common east of the base, only the drainage channel that flows through the CE bulk storage yard meets their habitat requirements on base. As shown in the photograph above, dense shoreline vegetation can provide adequate cover and screen the flock from detection.

The Common Teal are small ducks reaching only $37.5 \mathrm{~cm}$ in length. They are the same species as the Greenwinged Teal found in the United States. They are similar in appearance, but the Asian male population has a white wing bar that the North American male population lacks. Both have chestnut-brown colored heads with a dark green eye and ear patch. The bodies are generally greyish-brown. The females are mottled brown and well-camouflaged. In flight, both sexes display a green speculum bordered with white bars. 


\section{Gadwall}

Anas strepera

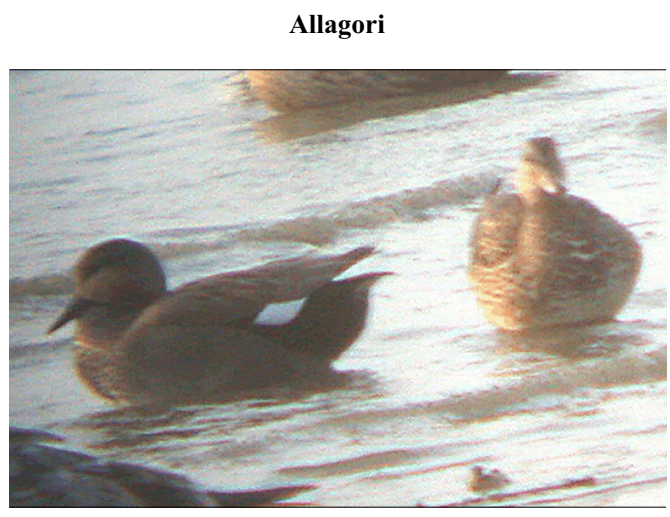

Status - Common winter visitor. Confirmed to be an uncommon winter visitor along the Yellow Sea tide line.

\begin{tabular}{|l|c|c|c|c|c|c|c|c|c|c|c|c|}
\hline \multicolumn{10}{|c|}{ Gadwall } \\
\hline & Jan & Feb & M ar & Apr & M ay & Jun & Jul & Aug & Sep & Oct & Nov & Dec \\
\hline Forests & & & & & & & & & & & & \\
\hline Wetlands & & & & & & & & & & & & \\
\hline Intertidal Zone & & U & & & & & & & & & & \\
\hline Airfield & & & & & & & & & & & & \\
\hline Cantonment & & & & & & & & & & & & \\
\hline
\end{tabular}

The Gadwall prefers freshwater open lakes, marshes, and rivers where it feeds largely on submerged plants. Its preference for freshwater systems likely explains why it is relatively uncommon on the mudflats adjacent to the base.

The Gadwall is the same species found in the United States. They are smaller than a Mallard reaching about $50 \mathrm{~cm}$ in length. The male is predominantly grey with a white belly. He has a black bill and a black rump and tail coverts. The female has mottled brown plumage and resembles a female Mallard, except with a white belly. The female also has a blackish bill with orange sides. At rest, a small white patch may be visible on the wings of both sexes, as shown above. In flight, field marks for both sexes include the white belly and white speculum. 


\section{Red-breasted Merganser \\ Merganser serrator}

\section{Badabiori}

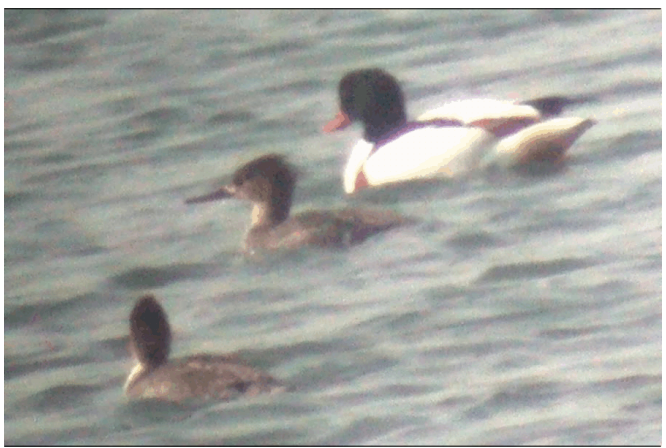

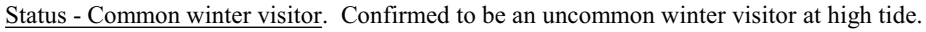

\begin{tabular}{|l|c|c|c|c|c|c|c|c|c|c|c|c|}
\hline \multicolumn{10}{|c|}{ Red-breasted Merganser } \\
\hline & Jan & Feb & M ar & Apr & M ay & Jun & Jul & Aug & Sep & Oct & Nov & Dec \\
\hline Forests & & & & & & & & & & & & \\
\hline Wetlands & & & & & & & & & & & & \\
\hline Intertidal Zone & & R & & & & & & & & & & U \\
\hline Airfield & & & & & & & & & & & & \\
\hline Cantonment & & & & & & & & & & & & \\
\hline
\end{tabular}

Above, two Red-breasted Mergansers are shown in the foreground with a Common Shelduck in the background. While in Korea during the winter months, Mergansers prefer marine and estuarine habitats. They are diving birds and are able to catch fish, crustaceans, and aquatic insects with their long thin, serrated bills.

The Red-breasted Merganser is the same species as is found in the United States. It is slightly shorter than a Mallard reaching about $55 \mathrm{~cm}$ in length and much more streamlined for swimming underwater. During the winter season, both sexes are a grey-brown with a reddish brown head and upper neck. Field marks during the winter months for both sexes include a shaggy double crest, whitish throat, and streaked breast. 


\section{Chinese Sparrowhawk}

Accipiter soloensis

\section{Bulgeunbaesaemae}

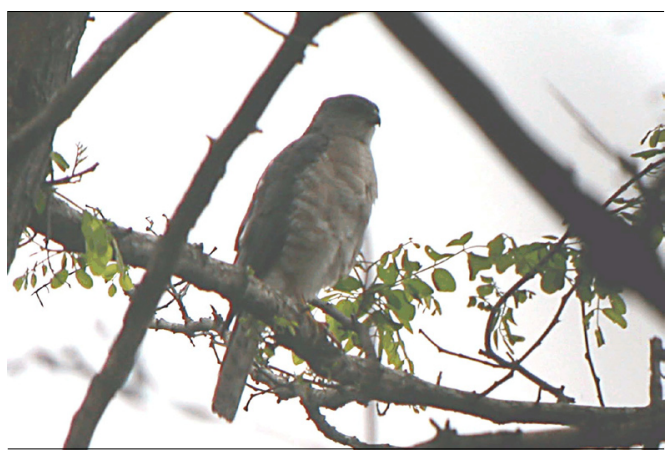

Status - Common summer visitor. Confirmed to be an uncommon summer visitor in the POL-north area.

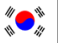

Cultural Property No. 323

\begin{tabular}{|l|c|c|c|c|c|c|c|c|c|c|c|c|}
\hline \multicolumn{10}{|c|}{ Chinese Sparrowhawk } \\
\hline & Jan & Feb & Mar & Apr & M ay & Jun & Jul & Aug & Sep & Oct & Nov & Dec \\
\hline Forests & & & & & U & & U & C & & & U & \\
\hline Wetlands & & & & & & & & & & & & \\
\hline Intertidal Zone & & & & & & & & & & & & \\
\hline Airfield & & & & & & & & & & & & \\
\hline Cantonment & & & & & & & & & & & & \\
\hline
\end{tabular}

The Chinese Sparrowhawk favors wooded hills with adjacent rice paddies or wetlands. At Kunsan, they are often observed flying sorties between the POL-north area and the adjacent rice paddies, apparently in search of frogs. They are sometimes referred to as "Frog Hawks," but they also feed on insects, particularly grasshoppers and cicadas.

The Chinese Sparrowhawk likely nests on the hillside adjacent to Wolf Pack Park, although a nest has site has not been discovered. During the winter months, Chinese Sparrowhawks migrate as far south as Taiwan along the Japanese archipelago.

The Chinese Sparrowhawk is a small $(\sim 30 \mathrm{~cm})$ hawk. Plumage is slate grey above with a pale orangish wash on breast and belly. In flight, they have white underwings with black tips. 


\section{Eurasian Sparrowhawk \\ Accipiter nisus}

\section{Saemae}

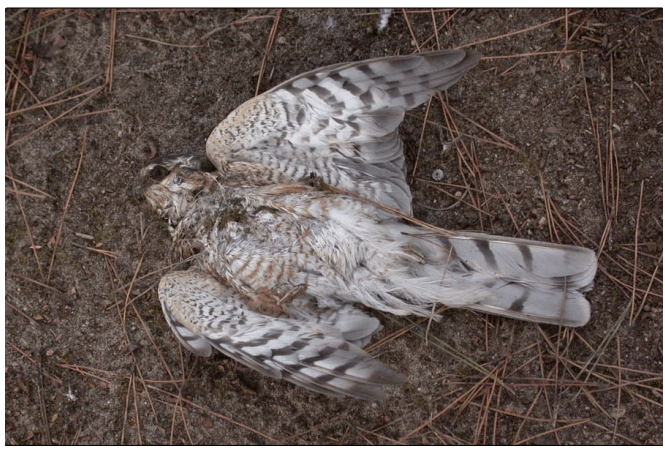

Status - Uncommon resident. Confirmed to be a rare resident.

Cultural Property No. 323

\begin{tabular}{|l|c|c|c|c|c|c|c|c|c|c|c|c|}
\hline \multicolumn{10}{|c|}{ Eurasian Sparrowhawk } \\
\hline & Jan & Feb & Mar & Apr & May & Jun & Jul & Aug & Sep & Oct & Nov & Dec \\
\hline Forests & & & R & & & & & & R & & & \\
\hline Wetlands & & & & & & & & & & & & \\
\hline Intertidal Zone & & & & & & & & & & & & \\
\hline Airficld & & & & & & & & & & & & \\
\hline Cantonment & & & & & & & & & & & & \\
\hline
\end{tabular}

The Eurasian Sparrowhawk is seldom sighted on Kunsan AB and was positively identified with the dead individual pictured above. They typically breed in mountain forests above $600 \mathrm{~m}$ elevation. They descend to the lowlands during the fall and winter non-breeding seasons. This Sparrowhawk's diet consists mainly of small woodland birds, insects, and rodents.

The Eurasian Sparrowhawk is slightly larger $(\sim 30-33 \mathrm{~cm})$ than the Chinese Sparrowhawk. Males are slatyblue above with a finely barred rufous breast. Rufous-colored cheeks are diagnostic field marks for the males. Females are grey-brown above with close brown bars on an otherwise white breast. The Eurasian Sparrowhawk's most notable field marks are a narrow white line above their eye and fine brown underwing lines. 


\section{Common Buzzard}

Buteo buteo

\section{Malttonggari}

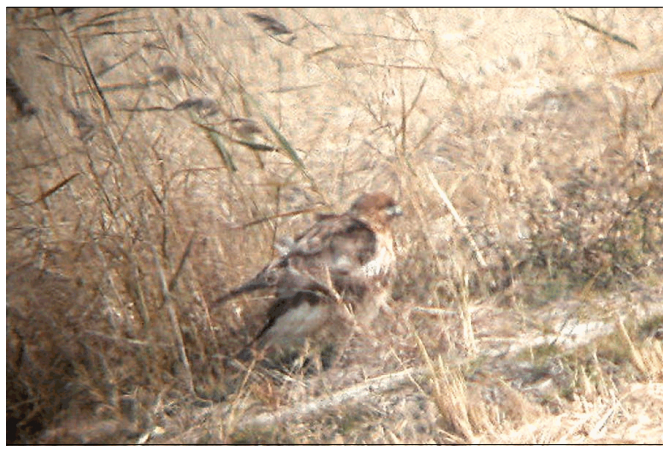

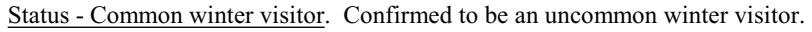

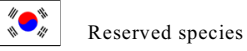

\begin{tabular}{|l|c|c|c|c|c|c|c|c|c|c|c|c|}
\hline \multicolumn{10}{|c|}{ Common Buzzard } \\
\hline & Jan & Feb & Mar & Apr & M ay & Jun & Jul & Aug & Sep & Oct & Nov & Dec \\
\hline Forests & R & & & & & & & & & & & \\
\hline Wetlands & & & & & & & & & & & & \\
\hline Intertidal Zone & & & & & & & & & & & & \\
\hline Airfield & & & & & & & & & & & U & \\
\hline Cantonment & & & & & & & & & & & & \\
\hline
\end{tabular}

During the winter months, the Common Buzzard hunts the open grasslands, agricultural fields, and foothills in the vicinity of the base for a wide variety of prey. They are known to take mammals as large as hares, birds as large as pheasants, as well as reptiles, amphibians, and insects.

Common Buzzards are large raptors ranging from 52 to $56 \mathrm{~cm}$ in length with a wingspan of 1.22 to $1.37 \mathrm{~m}$. Their plumage is variable. Most display a brown head and back with a dark-streaked pale breast. In flight, the best field marks include black wingtips and "wrist" patches, a short neck, and a rounded, unbarred tail. When soaring, the wings are held in a slight "V" with the tips slightly forward. 


\section{Peregrine Falcon}

Falco peregrinus

\section{Mae}

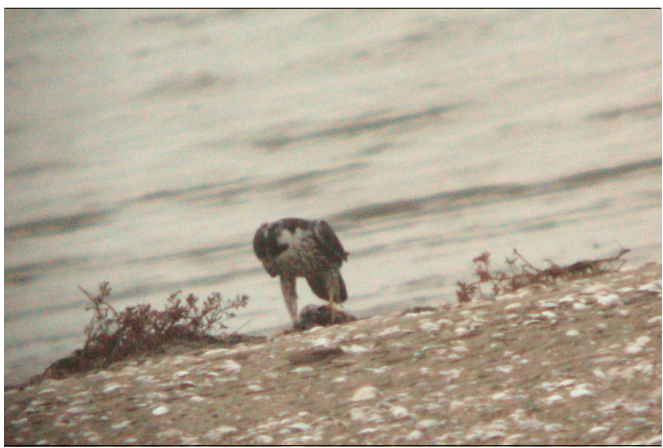

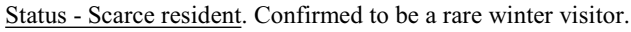

"1. Rare and Threatened species

Cultural Property No. 323

\begin{tabular}{|l|l|l|l|l|l|l|l|l|l|l|l|l|}
\hline \multicolumn{7}{|c|}{ Peregrine Falcon } \\
\hline & Jan & Feb & M ar & Apr & M ay & Jun & Jul & Aug & Sep & Oct & Nov & Dec \\
\hline Forests & & & & & & & & & & & & \\
\hline Wetlands & & & & & & & & & & & & \\
\hline Intertidal Zone & & R & & & & & & & & R & R & \\
\hline Airfield & & & & & & & & & & & & \\
\hline Cantonment & & & & & & & & & & & & \\
\hline
\end{tabular}

The Peregrine Falcon is one of the most spectacular falcons in the Northern Hemisphere. This is the same species as is found in the U.S. At Kunsan, it is most often observed along the Yellow Sea tide line just north of Big Coyote Hill. At this location, it is able to suddenly attack loafing ducks along the shoreline during high tides from a concealed perch on the hill.

A relatively large falcon, the Peregrine averages $45 \mathrm{~cm}$ in length with a $1.2 \mathrm{~m}$ wingspan. Its dark grey upper parts contrast with pale, lined underparts. The large bold "teardrop" is diagnostic for the Peregrine Falcon. 


\section{Eurasian Hobby \\ Falco subbuteo}

\section{Saeholligi}

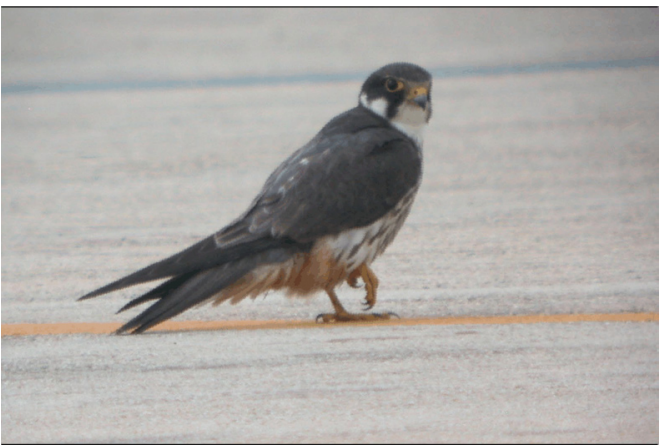

Status - Uncommon summer visitor. Confirmed to be a common summer visitor.

Reserved species

\begin{tabular}{|l|l|l|l|l|l|l|l|l|l|l|l|l|}
\hline \multicolumn{10}{|c|}{ Eurasian Hobby } \\
\hline & Jan & Feb & M ar & Apr & M ay & Jun & Jul & Aug & Sep & Oct & Nov & Dec \\
\hline Forests & & & & & & & & C & & & & \\
\hline Wetlands & & & & & & & & & & & & \\
\hline Intertidal Zone & & & & & & & & & & & & \\
\hline Airfield & & & & & & U & & C & U & & & \\
\hline Cantonment & & & & & & U & & C & & & & \\
\hline
\end{tabular}

The Hobby is a relentless hunter preying on other birds and dragonflies in flight. Although it prefers forest edges and sea cliffs, it has been observed atop the Officer's Club and along the sea wall. It is most often observed over the airfield, demonstrating spectacular aerobatic prowess in pursuit of Barn Swallows or Skylarks.

The Eurasian Hobby is only $30 \mathrm{~cm}$ in length, or about three-fourths the size of a Peregrine Falcon. Similar in appearance to the Peregrine, the Hobby has uniformly dark grey-brown upper parts and contrasting white underparts. The breast is heavily streaked, not lined or barred. The Hobby's "teardrops" are narrower, and the diagnostic field marks are the orange-red thighs and vent. 


\section{Common Kestrel}

Falco tinnunculus

\section{Hwangjorong-I}

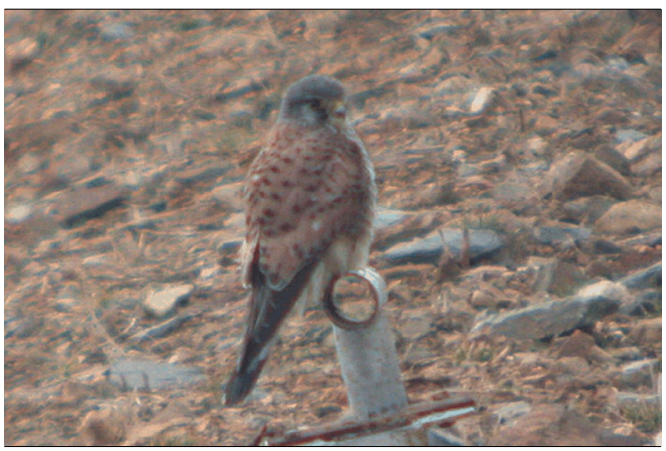

Status - Common resident. Confirmed to be a common year-round resident. They are confirmed to nest under dormitory eaves and in the POL-north area.

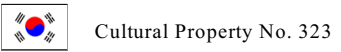

\begin{tabular}{|l|c|c|c|c|c|c|c|c|c|c|c|c|}
\hline \multicolumn{10}{|c|}{ Common Kestrel } \\
\hline & Jan & Feb & M ar & Apr & M ay & Jun & Jul & Aug & Sep & Oct & Nov & Dec \\
\hline Forests & & U & & & C & & & U & U & & & \\
\hline Wetlands & & & & & & & & & & & & \\
\hline Intertidal Zone & & & & & & & & & & & & \\
\hline Airfield & C & U & U & & C & C & C & C & C & C & C & U \\
\hline Cantonment & & U & & U & & C & C & C & C & & U & \\
\hline
\end{tabular}

Common Kestrels are the most common raptors on Kunsan AB. This falcon preys on small mammals, small birds, and insects. Unlike the Peregrine Falcon and Hobby, Kestrels generally do not become involved in lengthy pursuits. Instead, they characteristically hover suspended over the airfield with tail spread, searching for prey and then diving to capture it.

Field marks include rufous upper parts, an evident but not bold teardrop, and black, pointed wingtips. Males have grey heads and tails, as shown above. Females have brown upper parts, heads and tails.

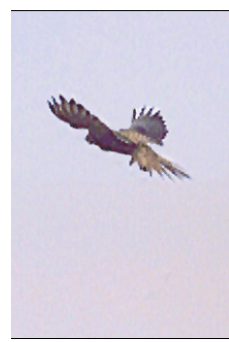




\section{Ring-necked Pheasant \\ Phasianus colchicus}

\section{Kkwong}

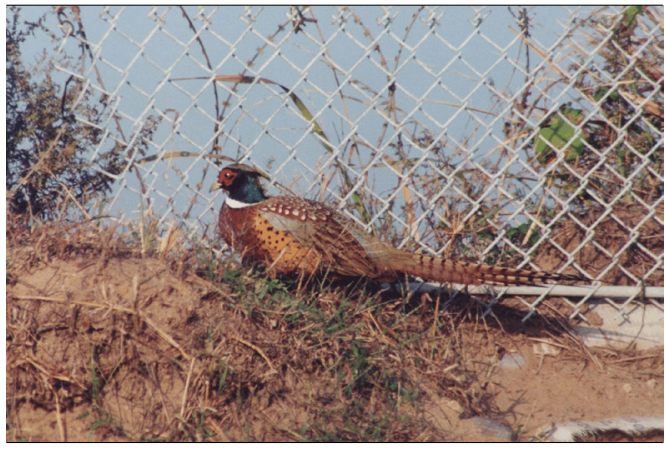

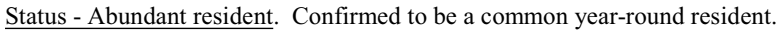

\begin{tabular}{|c|c|c|c|c|c|c|c|c|c|c|c|c|}
\hline \multicolumn{13}{|c|}{ Ring-necked Pheasant } \\
\hline & Jan & Feb & Mar & Apr & May & Jun & Jul & Aug & Sep & oct & Nov & Dec \\
\hline Forests & c & c & & & c & $\mathrm{c}$ & c & c & c & $\mathrm{c}$ & $\mathrm{c}$ & c \\
\hline \multicolumn{13}{|l|}{ Wetlands } \\
\hline \multicolumn{13}{|c|}{ Intertidal Zone } \\
\hline Airfield & c & c & c & c & c & c & c & c & c & c & c & c \\
\hline Cantonment & & $\mathrm{u}$ & c & & c & c & & c & & & c & \\
\hline
\end{tabular}

Native to Korea, they have been introduced worldwide, including the U.S., as a game bird. Ring-necked Pheasants occupy the POL-north area, airfield, and even the cantonment areas of the base. The individual shown has "adopted" one of the residences on Gunsmoke Hill as part of his territory. Common year-round, their numbers appear to have increased in recent years. They should be considered a serious BASH hazard.

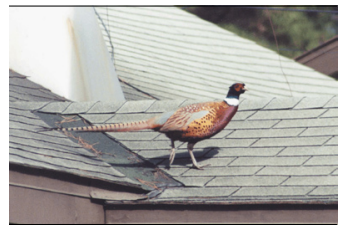

They are large, ground dwelling birds and prefer overgrown fence and razor-wire rows as well as woodland edges. Their varied diets include seeds, insects, and lizards. 


\section{Japanese Quail}

Coturnix japonica

\section{Mechuragi}

Not

Photographed

Status - Common winter visitor. Confirmed to be present in the vicinity of the present-day asbestos landfill area - August 19, 1999.

\begin{tabular}{|l|l|l|l|l|l|l|l|l|l|l|l|l|}
\hline \multicolumn{10}{|c|}{ Japanese Quail } \\
\hline & Jan & Feb & M ar & Apr & M ay & Jun & Jul & Aug & Sep & Oct & Nov & Dec \\
\hline Forests & & & & & & & & & & & & \\
\hline Wetlands & & & & & & & & & & & & \\
\hline Intertidal Zone & & & & & & & & & & & & \\
\hline Airfield & & & & & & & & R & & & & \\
\hline Cantonment & & & & & & & & & & & & \\
\hline
\end{tabular}

The Japanese Quail prefers the grasslands and cultivated fields around Kunsan during the non-breeding season. They are secretive, ground dwelling birds and are only apparent when flushed from cover. Then they fly low and rapidly for short distances before diving back under the cover of grass. As a result, they are probably more common than indicated.

Similar in size and habit to the Northern Bobwhite (Colinus virginianus), they prefer much the same habitat. They are small (20 cm long), brownish birds. Their round shape, distinctive whitish eye stripe, and rapid, low flight are the best field marks of this well-camouflaged bird. 


\title{
Ruddy Crake
}

Porzana fusca

\section{Soetteumbugisachon}

\author{
Not \\ Photographed
}

Status - Uncommon summer visitor. Confirmed on only two occasions - August 16, 1999, and October 17, 2001.

\begin{tabular}{|l|l|l|l|l|l|l|l|l|l|l|l|l|}
\hline \multicolumn{1}{|c|}{ Ruddy Crake } \\
\hline & Jan & Feb & M ar & Apr & M ay & Jun & Jul & Aug & Sep & Oct & Nov & Dec \\
\hline Forests & & & & & & & & & & & & \\
\hline Wetlands & & & & & & & & & & & & \\
\hline Intertidal Zone & & & & & & & & & & & & \\
\hline Airfield & & & & & & & & R & & R & & \\
\hline Cantonment & & & & & & & & & & & & \\
\hline
\end{tabular}

The Ruddy Crake is the most common rail in Korea. It prefers rice paddy and marsh habitats. On Kunsan, both sightings were made in the same location in a stand of tall sea grasses in the small bay east of Big Coyote Hill. It is likely they breed and nest locally. A dead individual was recorded in October. It was impaled on razor wire in an apparent failed attempt to fly over the wire.

A relatively small bird ( $22.5 \mathrm{~cm}$ long), the Ruddy Crake has brown upper parts, a small white throat patch, and a rusty-red breast. The lower belly and sides are barred with brown and white. Red legs are the diagnostic field mark. 


\section{Moorhen}

\section{Gallinula chloropus}

\section{Soemuldak}

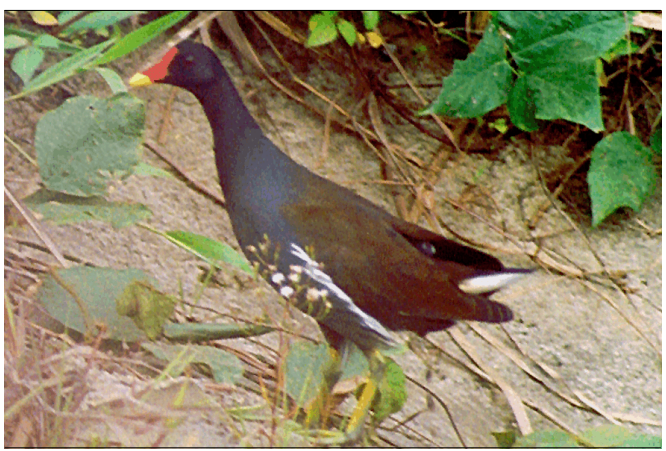

Status - Common summer visitor. Confirmed at Kunsan AB on April 30, 2001.

\begin{tabular}{|l|l|l|l|l|l|l|l|l|l|l|l|l|}
\hline \multicolumn{10}{|c|}{ Moorhen } \\
\hline & Jan & Feb & Mar & Apr & May & Jun & Jul & Aug & Sep & Oct & Nov & Dec \\
\hline Forests & & & & & & & & & & & & \\
\hline Wetlands & & & & R & & & & & & & & \\
\hline Intertidal Zone & & & & & & & & & & & & \\
\hline Airfield & & & & & & & & & & & & \\
\hline Cantonment & & & & & & & & & & & & \\
\hline
\end{tabular}

The only Moorhen, or Common Gallinule, recorded was sighted in a small residential pond immediately adjacent to the perimeter fence in Haji Village. Moorhens prefer heavily vegetated ponds and wetlands. It is likely that they nest locally.

Their feet are very large with long toes. This adaptation distributes their weight and allows them to walk on aquatic vegetation. They also swim well and jerk their heads and necks back and forth when swimming.

Fairly large (32.5 cm long), the Moorhen is a duck-like bird. Overall they are dark grey with brown wings. Field marks include a bright red facial shield, a yellow-tipped red bill, and a white flank stripe and undertail feathers. 


\section{Little Ringed Plover}

Charadrius dubius

\section{Kkomamulttesae}

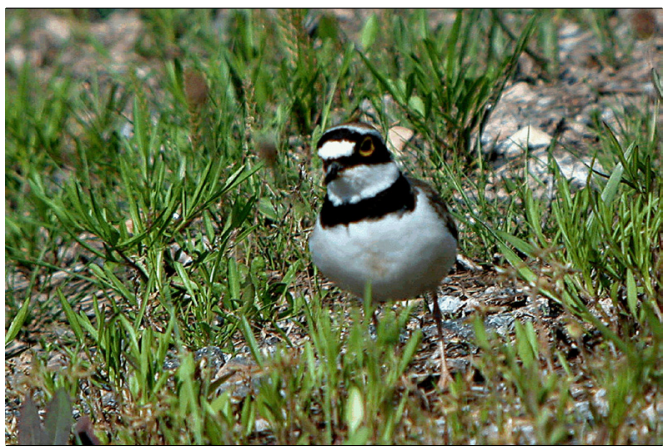

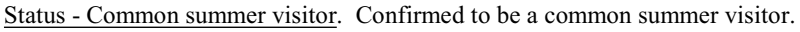

\begin{tabular}{|l|c|c|c|c|c|c|c|c|c|c|c|c|}
\hline \multicolumn{10}{|c|}{ Little Ringed Plover } \\
\hline & Jan & Feb & Mar & Apr & May & Jun & Jul & Aug & Sep & Oct & Nov & Dec \\
\hline Forests & & & & & & & & & & & & \\
\hline Wetlands & & & & & & & & & & & & \\
\hline Intertidal Zone & & & C & C & C & C & C & C & & & R & \\
\hline Airfield & & & C & C & C & C & C & & & & & \\
\hline Cantonment & & & U & & U & U & & & & & & \\
\hline
\end{tabular}

This plover is similar in habit to the North American Killdeer (C. vociferus). Both species nest in gravelly habitats like road shoulders, gravel parking lots, and CE yards. When approached, they call loudly and prefer to run rather than fly away.

When young birds or nests are nearby, both species feign a broken wing and hobble just beyond reach to lure potential predators away. When safely away from the nest or young, they take flight.

Little Ringed Plovers are small $(15 \mathrm{~cm})$ with brown upper parts, white underparts, and a single black neck band. The diagnostic field mark is the bright, distinct yellow eye ring. In flight, they lack the wing bars typical of other plovers.

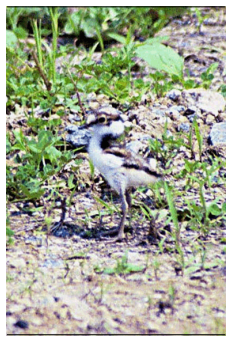




\section{Kentish Plover \\ Charadrius alexandrinus}

Huinmulttesae

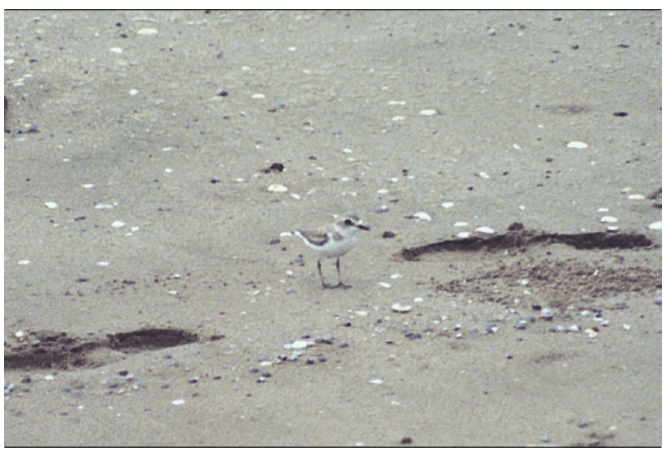

Status - Common passage migrant. Confirmed to be present year-round.

\begin{tabular}{|l|c|c|c|c|c|c|c|c|c|c|c|c|}
\hline \multicolumn{10}{|c|}{ Kentish Plover } \\
\hline & Jan & Feb & M ar & Apr & M ay & Jun & Jul & Aug & Sep & Oct & Nov & Dec \\
\hline Forests & & & & & & & & & & & & \\
\hline Wetlands & & & & & & & & & & & & \\
\hline Intertidal Zone & U & U & C & U & U & C & C & U & A & A & U & U \\
\hline Airfield & & & & & & & & & & & & \\
\hline Cantonment & & & & & & & & & & & & \\
\hline
\end{tabular}

The Kentish Plover is the same species as the "Snowy Plover" of North America. It prefers to nest on sandy beaches and forage on the mudflats and along the tide line. At Kunsan, the Kentish Plover does not occur in gravelly habitats of the Little Ringed Plover. The primary nesting area appears to be throughout China and central Asia. However, with their year-round presence at Kunsan, it is likely they also breed in the vicinity.

The Kentish Plover is also a small bird (17 cm long) with a pale brown upper parts and clear white stomach. It has only a pair of dark shoulder "epaulettes" instead of the full neck band typical of other shoreline plovers. Leg color is usually dark and in flight, the Kentish Plover displays a white wing bar. 


\section{Mongolian Plover \\ Charadrius mongolus}

\section{Wangnunmulttesae}

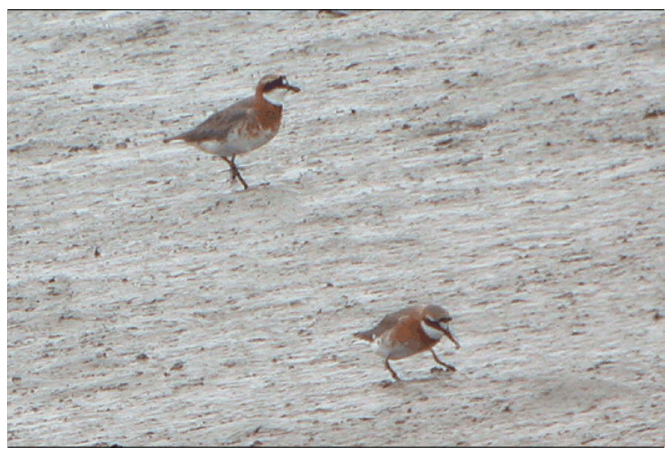

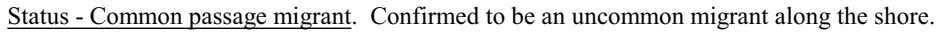

\begin{tabular}{|l|c|c|c|c|c|c|c|c|c|c|c|c|}
\hline \multicolumn{10}{|c|}{ Mongolian Plover } \\
\hline & Jan & Feb & M ar & Apr & M ay & Jun & Jul & Aug & Sep & Oct & Nov & Dec \\
\hline Forests & & & & & & & & & & & & \\
\hline Wetlands & & & & & & & & & & & & \\
\hline Intertidal Zone & & & & & u & & & c & U & & & \\
\hline Airfield & & & & & & & & & & & & \\
\hline Cantonment & & & & & & & & & & & & \\
\hline
\end{tabular}

Except during the peak of migration when flocks numbering in the hundreds may be present along the Yellow Sea tide line, the Mongolian Plover is relatively uncommon. They breed along the shore of the Kamchatka Peninsula and into the Siberian tundra. Although not observed near the base in winter, some individuals appear to overwinter along the Geum River in Kunsan.

A little larger than the Kentish and Little Ringed Plovers, Mongolian Plovers average $19 \mathrm{~cm}$ in length. During the breeding season, the males have grey upper parts and a white belly. A thin black line separates the bright rusty red breast from an unmarked white throat and connects with a black eye mask. The duller females lack the striking contrasts of the males but their patterns are similar. 


\section{Pacific Golden Plover \\ Pluvialis fulva}

\section{Geomeun-gaseummulttesae}

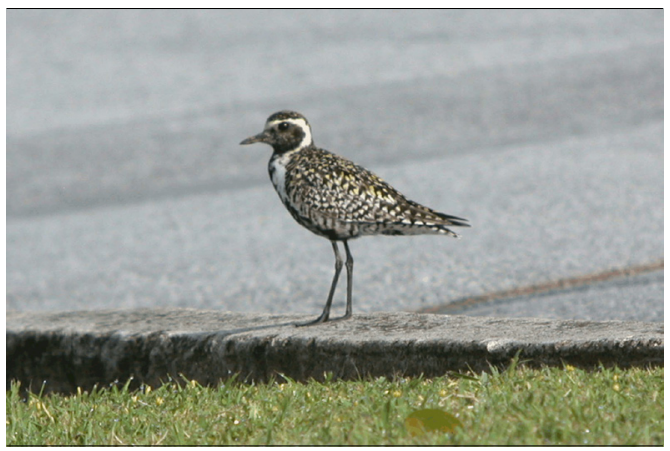

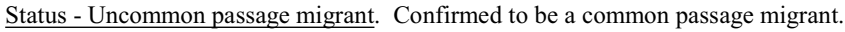

\begin{tabular}{|l|c|c|c|c|c|c|c|c|c|c|c|c|}
\hline \multicolumn{10}{|c|}{ Pacific Golden Plover } \\
\hline & Jan & Feb & Mar & Apr & May & Jun & Jul & Aug & Sep & Oct & Nov & Dec \\
\hline Forests & & & & & & & & & & & & \\
\hline Wetlands & & & & & & & & & & & & \\
\hline Intertidal Zone & & & & & R & & & C & C & & & \\
\hline Airfield & & & & & & & & & & & & \\
\hline Cantonment & & & & & R & & & R & & & & \\
\hline
\end{tabular}

The Pacific Golden Plover appears to be somewhat less common during the spring migration than during the fall migration. They prefer mudflats, rice paddies, and even grassland habitats. The individual above was photographed along the edge of the golf course. The Pacific Golden Plover breeds in the Arctic tundra.

The Pacific Golden Plover is a relatively large plover averaging $25 \mathrm{~cm}$ in length. In breeding plumage, the males have a finely patterned, golden-yellow and black back. The underparts are black. A diagnostic white band across the forehead and down the breast sides separates the patterned crown and back from the black underparts. Non-breeding male plumage closely resembles the females and lacks the diagnostic white band and black underparts. In flight, field marks are dark underwings, a dark rump, and a faint wing bar. 


\section{Grey Plover \\ Pluvialis squatarola}

\section{Gae-kkwong}

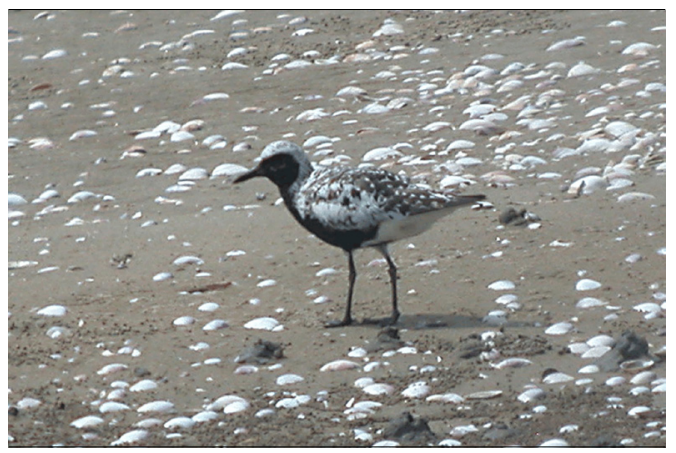

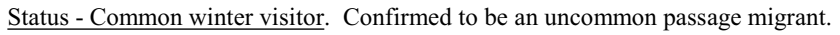

\begin{tabular}{|l|c|c|c|c|c|c|c|c|c|c|c|c|}
\hline \multicolumn{10}{|c|}{ Grey Plover } \\
\hline & Jan & Feb & M ar & Apr & M ay & Jun & Jul & Aug & Sep & Oct & Nov & Dec \\
\hline Forests & & & & & & & & & & & & \\
\hline Wetlands & & & & & & & & & & & & \\
\hline Intertidal Zone & & & & & R & & & C & U & R & U & \\
\hline Airfield & & & & & & & & & & & & \\
\hline Cantonment & & & & & & & & & & & & \\
\hline
\end{tabular}

The Grey (or Black-bellied) Plover is numerically more common and is present at Kunsan for a longer period of time during the fall migration than the Pacific Golden Plover. They prefer the saltwater habitats of estuaries, sand beaches, and mudflats. The Grey Plover nests and breeds in the Arctic tundra and winters in southeastern Asia.

The Grey Plover is a large plover measuring $29 \mathrm{~cm}$ in length. In breeding plumage, the male's upper parts are generally silver with black spots. A broad white band stretching from the forehead to the vent separates a pure black breast and belly from the upper parts. In non-breeding plumage, both sexes are grey over all lighter and finely streaked below, darker and patterned above. In flight, field marks are white underwings, black axillaries, and a white rump. 


\section{Northern Lapwing}

Vanellus vanellus

\section{Daeng-gimulttesae}

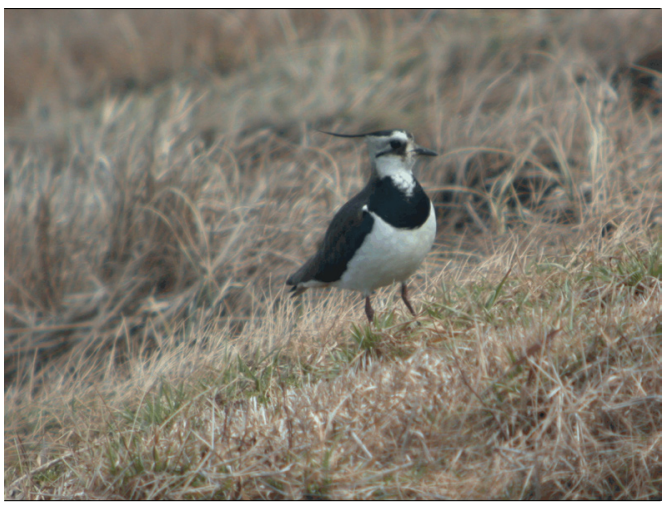

Status - Common winter visitor. Confirmed as a rare winter visitor on the airfield. Only one individual was recorded on February 25, 2004.

\begin{tabular}{|l|c|c|c|c|c|c|c|c|c|c|c|c|}
\hline \multicolumn{10}{|c|}{ Northern Lapwing } \\
\hline & Jan & Feb & M ar & Apr & M ay & Jun & Jul & Aug & Sep & Oct & Nov & Dec \\
\hline Forests & & & & & & & & & & & & \\
\hline Wetlands & & & & & & & & & & & & \\
\hline Intertidal Zone & & & & & & & & & & & & \\
\hline Airfield & & R & & & & & & & & & & \\
\hline Cantonment & & & & & & & & & & & & \\
\hline
\end{tabular}

The Northern Lapwing is a common winter visitor to many portions of Korea. It is usually associated with rice paddies, marshes, and lake shores - all freshwater systems. They breed throughout central Asia and northeastern China and winter in Korea, Japan, and southern Asia.

The Northern Lapwing is a distinctive, large plover reaching $32 \mathrm{~cm}$ in length. They have a black crest, bill, and facial marks. Their winter plumage is dark glossy green above with a white belly and vent. The breast is black. They have distinctive orange legs and feet. 


\section{Eurasian Oystercatcher \\ Haematopus ostralegus}

\section{Geomeunmeorimulttesae}

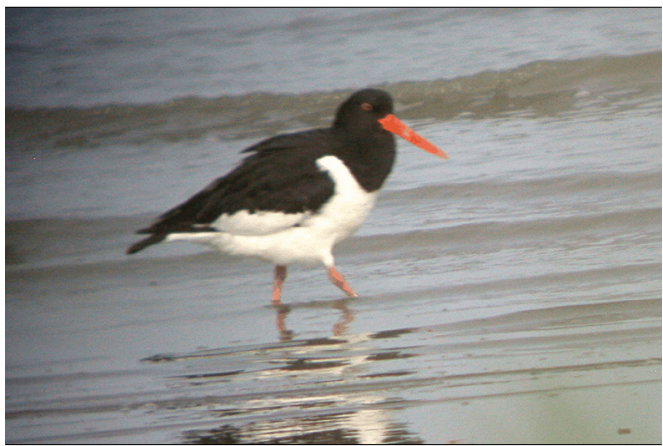

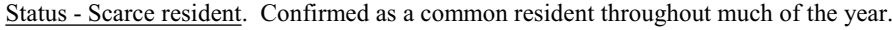

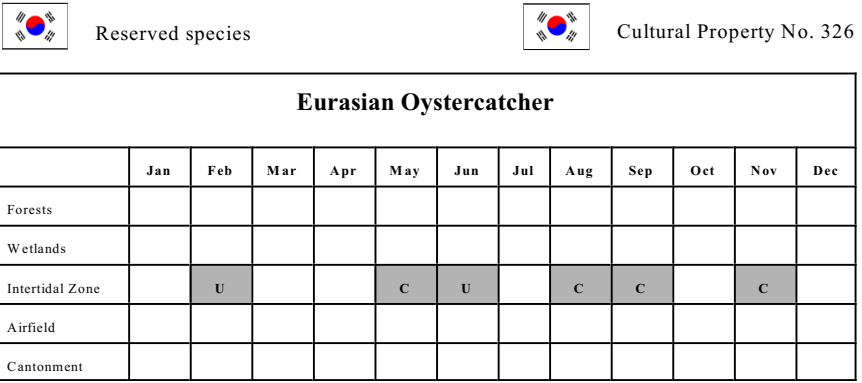

During low tides, the Eurasian Oystercatcher frequents the rocky outcrops at the base of Big Coyote Hill and the offshore shell bars. During the earlier years of the survey, only two or three individuals were observed at any given time. More recently, their numbers have swelled into flocks exceeding 100 individuals.

The Eurasian Oystercatcher is a large bird reaching $45 \mathrm{~cm}$ in length. They have black heads and backs with unmarked white under parts. Most distinctive are their large black-tipped orange bills, orange legs, and red eyes. 


\section{Red-necked Stint}

Calidris ruficollis

\section{Jomdoyo}

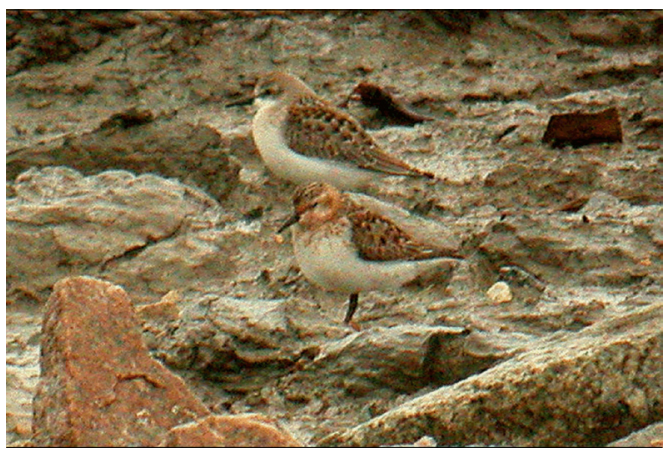

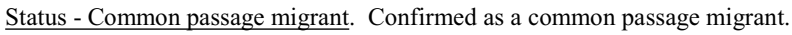

\begin{tabular}{|l|l|l|l|l|l|l|l|l|l|l|l|l|}
\hline \multicolumn{10}{|c|}{ Red-necked Stint } \\
\hline & Jan & Feb & Mar & Apr & M ay & Jun & Jul & Aug & Sep & oct & Nov & Dec \\
\hline Forests & & & & & & & & & & & & \\
\hline Wettands & & & & & & & & & & & & \\
\hline Intertidal Zone & & & & A & C & & u & c & u & & u & \\
\hline Airfield & & & & & & & & & & & & \\
\hline Cantonment & & & & & & & & & & & & \\
\hline
\end{tabular}

The Red-necked Stint is the most common migrant stint in the vicinity of Kunsan AB. They nest and breed along the shores of the Bering Sea and overwinter from Taiwan, southward. The estuaries, mudflats, and salt pans in the vicinity of Kunsan $\mathrm{AB}$ are their preferred habitats during migration.

Only about $15 \mathrm{~cm}$ long, the Red-necked Stint is similar to several other species of stints. But during the breeding season, the males have a copper-colored face, neck, and upper breast. Their backs are mottled in black, brown, and copper. The copper plumage tones are lost during the non-breeding season. They have a short black bill and black legs. In flight, they display a narrow white wing band. 


\section{Sharp-tailed Sandpiper \\ Calidris acuminata}

\section{Amerikamechuragidoyo}

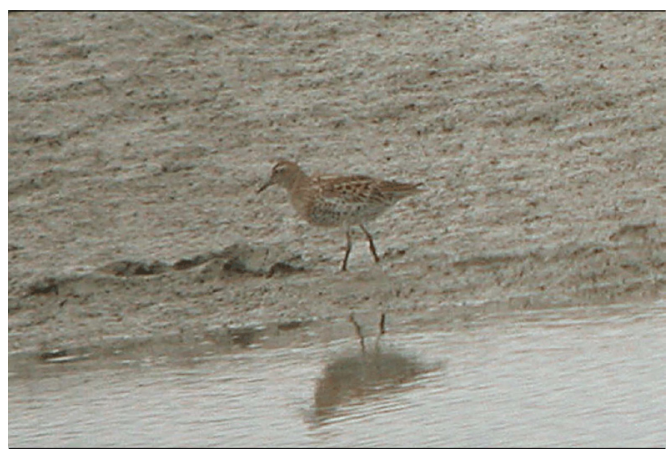

Status - Common passage migrant. Confirmed to be an uncommon passage migrant near the base.

\begin{tabular}{|l|l|l|l|l|l|l|l|l|l|l|l|l|l|}
\hline \multicolumn{10}{|c|}{ Sharp-tailed Sandpiper } \\
\hline & Jan & Feb & M ar & Apr & M ay & Jun & Jul & Aug & Sep & Oct & Nov & Dec \\
\hline Forests & & & & & & & & & & & & \\
\hline Wetlands & & & & & & & & & & & & \\
\hline Intertidal Zone & & & & & & & & U & & & & \\
\hline Airfield & & & & & & & & & & & & \\
\hline Cantonment & & & & & & & & & & & & \\
\hline
\end{tabular}

The Sharp-tailed Sandpiper is a common spring and fall migrant in the Kunsan area. Although common in terms of occurrence, it never appears in large numbers. Most often, individuals are embedded in large flocks of Dunlin (C. alpina). They breed along the coastline of the Arctic Sea in both Siberia and Alaska and overwinter in southeast Asia.

The Sharp-tailed Sandpiper is a medium-sized sandpiper reaching about $22 \mathrm{~cm}$ in length. Above, it is coppery-brown with black spotting and light edges on the back feathers. Breasts are dull brown with indistinct spots. The flanks appear greyish. The legs are yellow-green. Distinctive field marks during the non-breeding season include a rufous cap and a broad whitish eyebrow. 


\section{Dunlin \\ Calidris alpina}

\section{Minmuldoyo}

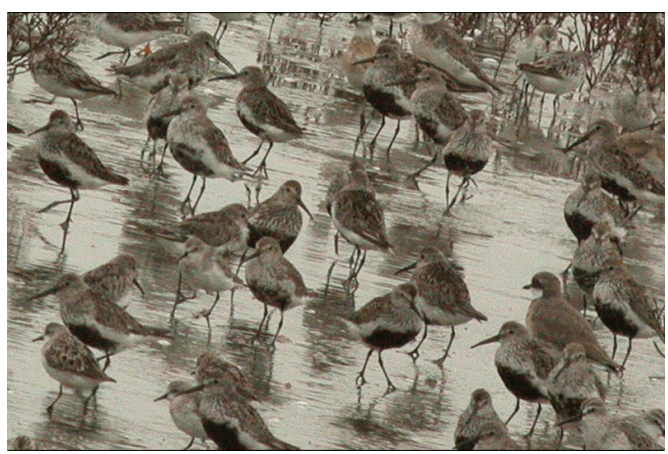

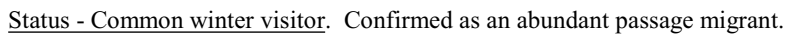

\begin{tabular}{|l|c|c|c|c|c|c|c|c|c|c|c|c|}
\hline \multicolumn{10}{|c|}{ Dunlin } \\
\hline & Jan & Feb & Mar & Apr & May & Jun & Jul & Aug & Sep & Oct & Nov & Dec \\
\hline Forests & & & & & & & & & & & & \\
\hline Wetlands & & & & & & & & & & & & \\
\hline Intertidal Zone & & & & A & A & & & & U & U & A & \\
\hline Airfield & & & & & & & & & & & & \\
\hline Cantonment & & & & & & & & & & & & \\
\hline
\end{tabular}

Dunlin prefer estuaries, mudflats, and saltpans in the vicinity of Kunsan AB during migration. They nest and breed along the shores of the Kamchatka Peninsula, Bering Sea, and Arctic Ocean. They overwinter from Korea and Japan, southward. They are common throughout the winter months along the Geum River.

Medium sized ( $22 \mathrm{~cm}$ long), the male Dunlin's breeding plumage is distinctive with a conspicuous black belly patch. The males have a reddish back with black spots and a finely streaked light breast. The female is brownish and the breast is washed in grey-brown with no belly patch. In the winter, the males resemble the female. Aside from the diagnostic belly patch, the best field mark is the sturdy, black, somewhat down-turned bill.

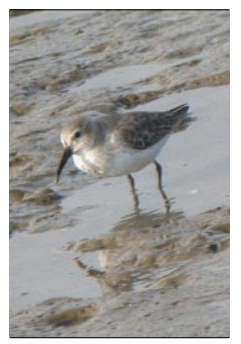




\section{Red Knot}

Calidris canutus

\section{Bulgeungaseumdoyo}

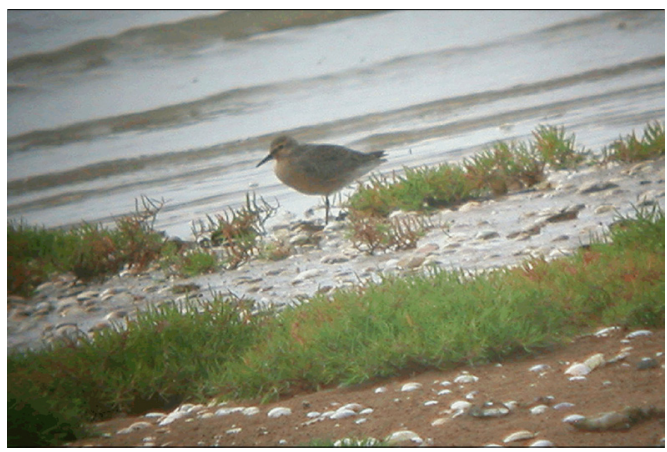

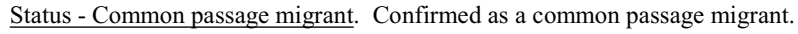

\begin{tabular}{|l|l|l|l|l|l|l|l|l|l|l|l|l|}
\hline \multicolumn{10}{|c|}{ Red Knot } \\
\hline & Jan & Feb & M ar & Apr & M ay & Jun & Jul & Aug & Sep & Oct & Nov & Dec \\
\hline Forests & & & & & & & & & & & & \\
\hline Wetlands & & & & & & & & & & & & \\
\hline Intertidal Zone & & & & C & & & & & & & & \\
\hline Airfield & & & & & & & & & & & & \\
\hline Cantonment & & & & & & & & & & & & \\
\hline
\end{tabular}

Red Knots occur in relatively small numbers embedded in very large flocks of Great Knots (C. tenuirostris) as they pass through the Kunsan area. They tend to congregate with Great Knots on the mudflats of the Mangyeung Estuary along the base's southern edge. The flocks are wary and tend to stay well away from human activity. They nest and breed in the high latitudes of the Arctic tundra and overwinter in the Southern Hemisphere.

Red Knots are chunky, short-legged waders that reach $27 \mathrm{~cm}$ in length. The breeding adult is dappled brown, black, and chestnut on the upper parts with a rusty chestnut face and breast. During non-breeding periods, the reddish tones disappear, leaving a pale grey back and white underparts. 


\section{Great Knot}

Calidris tenuirostris

\section{Bulgeuneokkaedoyo}

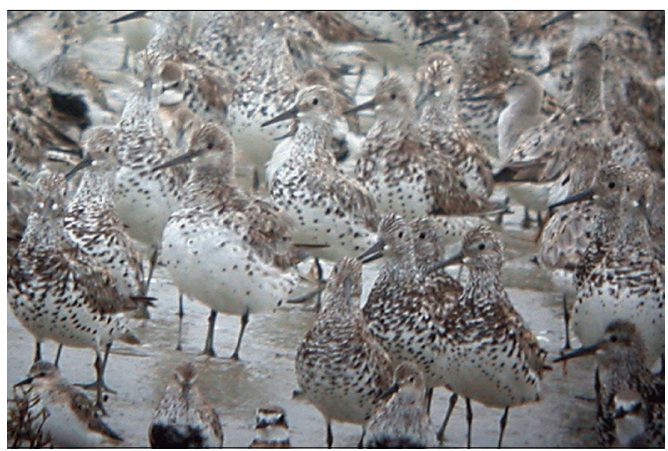

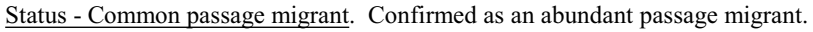

\begin{tabular}{|l|c|c|c|c|c|c|c|c|c|c|c|c|}
\hline \multicolumn{10}{|c|}{ Great Knot } \\
\hline & Jan & Feb & Mar & Apr & May & Jun & Jul & Aug & Sep & Oct & Nov & Dec \\
\hline Forests & & & & & & & & & & & & \\
\hline Wetlands & & & & & & & & & & & & \\
\hline Intertidal Zone & & & R & A & A & & & A & C & R & & \\
\hline Airfield & & & & & & & & & & & & \\
\hline Cantonment & & & & & & & & & & & & \\
\hline
\end{tabular}

Flocks of Great Knots numbering into the thousands are common during the spring and fall migrations. Most often, the flocks congregate along the mudflat tide line in the Mangyeung Estuary, but they seem to avoid the area immediately adjacent to the base.

The Great Knot is only slightly larger than the Red Knot (C. canutus), reaching 28 $\mathrm{cm}$ in length. They have a longer bill and lack the reddish coloration on the head, back, and breast. In general, their backs are grey-mottled, the head is grey, and the breast and flanks are heavily streaked with black.

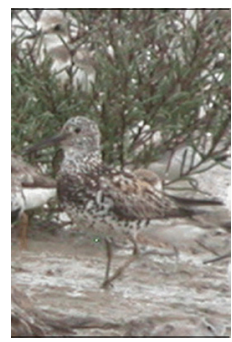




\section{Ruddy Turnstone}

Arenaria interpres

\section{Kkokkadoyo}

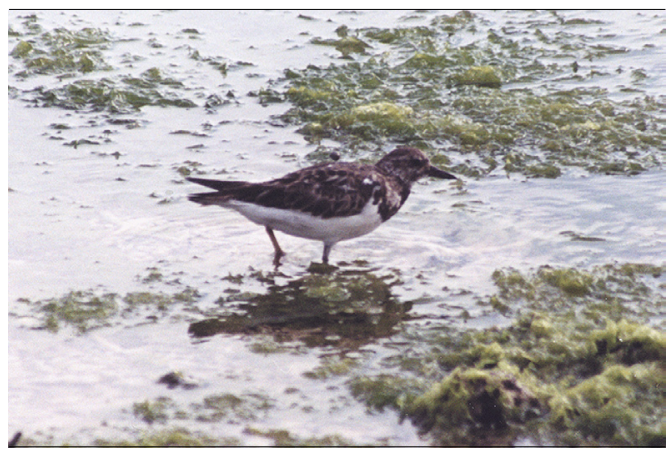

Status - Common passage migrant. Confirmed to be a rare passage migrant in the spring but more numerous in the fall.

\begin{tabular}{|l|l|l|l|l|l|l|l|l|l|l|l|l|l|}
\hline \multicolumn{10}{|c|}{ Ruddy Turnstone } \\
\hline & Jan & Feb & M ar & Apr & M ay & Jun & Jul & Aug & Sep & Oct & Nov & Dec \\
\hline Forests & & & & & & & & & & & & \\
\hline Wetlands & & & & & & & & & & & & \\
\hline Intertidal Zone & & & & R & & & & U & & & & \\
\hline Airfield & & & & & & & & & & & & \\
\hline Cantonment & & & & & & & & & & & & \\
\hline
\end{tabular}

Ruddy Turnstones prefer coastal marine environments ranging from rocky or sandy shores to mudflats. Turnstones use their stout, slightly upturned bills to flip aside small stones and seashells in search of food hence their common name. They nest and breed along the Arctic Ocean's coast and overwinter in southeastern Asia. This is the same species as occurs in North America, breeding in the high latitudes of the Arctic and wintering in southern California and along the Gulf of Mexico coastline.

Ruddy Turnstones are medium-sized sandpipers reaching about $24 \mathrm{~cm}$ in length. The individual pictured above was in non-breeding plumage including a blackish-brown back and head with a black patterned breast and white underparts. Breeding plumage incorporates the development of a black-and-white head and bib with a black-and-chestnut back. Good field marks are bright orange legs and a complex pattern of black, white, and chestnut on the back, wings, and tail. 


\section{Common Redshank}

Tringa totanus

\section{Bulgeunbaldoyo}

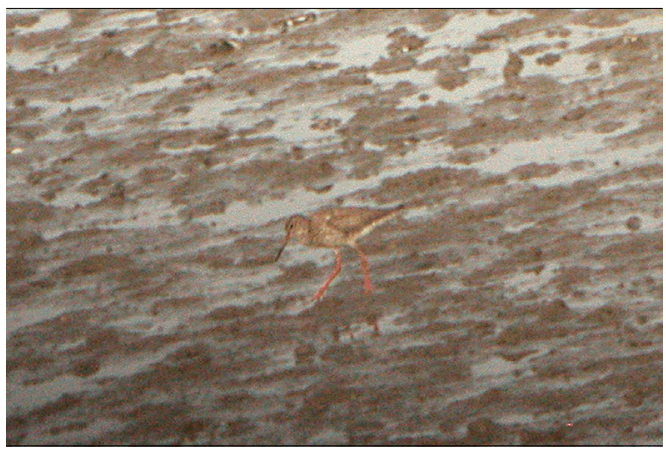

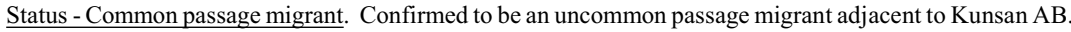

\begin{tabular}{|l|l|l|l|l|l|l|l|l|l|l|l|l|}
\hline \multicolumn{10}{|c|}{ Common Redshank } \\
\hline & Jan & Feb & M ar & Apr & M ay & Jun & Jul & Aug & Sep & Oct & Nov & Dec \\
\hline Forests & & & & & & & & & & & & \\
\hline Wetlands & & & & & & & & & & & & \\
\hline Intertidal Zone & & & & & & R & & U & & & & \\
\hline Airfield & & & & & & & & & & & & \\
\hline Cantonment & & & & & & & & & & & & \\
\hline
\end{tabular}

Common Redshanks prefer brackish marshes and mudflats and may be occasionally found in rice paddies. In the vicinity of Kunsan $A B$, they are more often observed in the saltpan areas east of the base. They breed throughout central Asia and overwinter in southern China and southeastern Asia.

Common Redshanks are medium-sized, long-legged wading birds averaging 27.5 $\mathrm{cm}$ in length. They have uniformly grey-brown upper parts with dark brown streaks on a white throat and breast. Diagnostic field marks are the reddish-orange legs and a long, straight orange bill that is dark near the tip. In flight, they display white under wings, lower back, rump, and trailing edge of the wings.

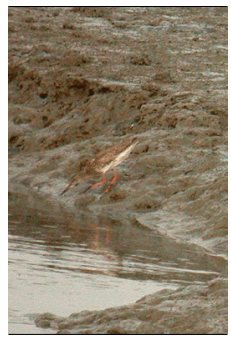




\section{Greenshank}

Tringa nebularia

\section{Cheongdaridoyo}

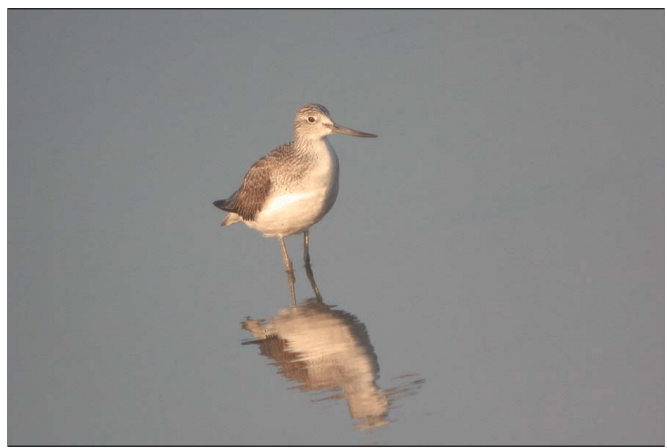

Status - Common passage migrant. Confirmed as a common passage migrant and summer resident.

\begin{tabular}{|l|l|l|l|l|l|l|l|l|l|l|l|l|l|}
\hline \multicolumn{10}{|c|}{ Greenshank } \\
\hline & Jan & Feb & M ar & Apr & M ay & Jun & Jul & Aug & Sep & Oct & Nov & Dec \\
\hline Forests & & & & & & & & & & & & \\
\hline Wetlands & & & & & & & & & & & & \\
\hline Intertidal Zone & & & & C & C & & C & C & C & C & C & \\
\hline Airfield & & & & & & & & & & & & \\
\hline Cantonment & & & & & & & & & & & & \\
\hline
\end{tabular}

Greenshanks frequent estuaries and mudflats as well as freshwater marshes, rice paddies, and drainage ditches. They nest and breed in the taiga and steppe latitudes of Asia. Wintering grounds are in southern China and southeastern Asia. Some non-breeding individuals remain in the Kunsan area through the summer months.

Greenshanks reach $35 \mathrm{~cm}$ in length. As their name implies, their long legs are greenish. They have greyish-brown heads, backs, and wings

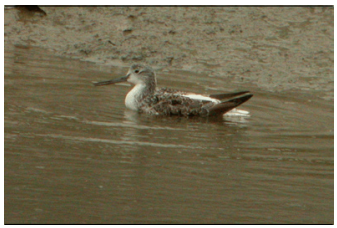
over a greyish-white breast and undersides. In breeding plumage, they have black streaks on their otherwise white head, neck, breast, and flanks. Field marks are a stout slightly upturned bill, white back, rump, and tail, and unmarked wings. 


\section{Green Sandpiper}

Tringa ochropus

\section{Ppikppikdoyo}

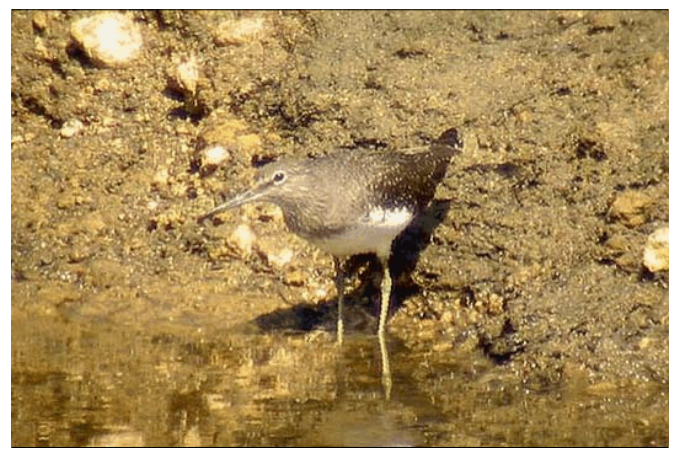

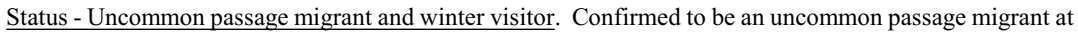
Kunsan AB.

\begin{tabular}{|l|l|l|l|l|l|l|l|l|l|l|l|l|}
\hline \multicolumn{10}{|c|}{ Green Sandpiper } \\
\hline & Jan & Feb & Mar & Apr & M ay & Jun & Jul & Aug & Sep & Oct & Nov & Dec \\
\hline Forests & & & & & & & & & & & & \\
\hline Wettands & & & & & & & & U & & & & \\
\hline Intertidal Zone & & & & & & & & & & & & \\
\hline Airfield & & & & & & & & & & & & \\
\hline Cantonment & & & & & & & & & & & & \\
\hline
\end{tabular}

The Green Sandpiper prefers freshwater marshes and river edges. At Kunsan, they can be found in waterfilled ruts on the airfield. Not gregarious, they are often solitary or in small, mixed flocks with Common (Actitis hypoleucos) and Wood (T. glareola) Sandpipers. They breed throughout the taiga of Siberia and overwinter throughout much of China, Japan, and southern South Korea.

A medium-sized sandpiper, the Green Sandpiper reaches $24 \mathrm{~cm}$ in length. Overall, they are dark brown above with many small white spots. The undersides are unmarked white. The white breast is heavily streaked during the breeding season but fades to a brownish wash during the winter months. Field marks include a distinct whitish eye ring with a faint whitish eyebrow and in flight, dark underwings, a white rump, and a white tail with dark bars near the tip. 


\section{Terek Sandpiper}

Xenus cinereus

\section{Dwitburidoyo}

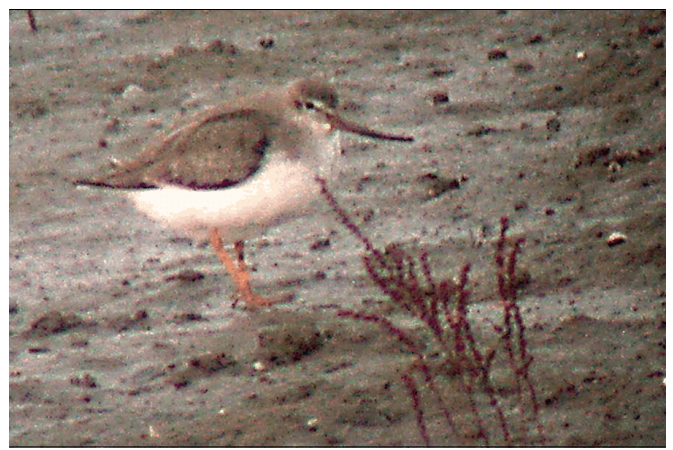

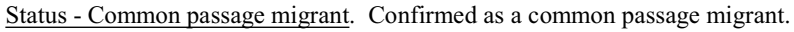

\begin{tabular}{|l|c|c|c|c|c|c|c|c|c|c|c|c|}
\hline \multicolumn{10}{|c|}{ Terek Sandpiper } \\
\hline & Jan & Feb & M ar & Apr & M ay & Jun & Jul & Aug & Sep & Oct & Nov & Dec \\
\hline Forests & & & & & & & & & & & & \\
\hline Wetlands & & & & & & & & & & & & \\
\hline Intertidal Zone & & & & U & C & & & C & C & U & U & \\
\hline Airfield & & & & & & & & & & & & \\
\hline Cantonment & & & & & & & & & & & & \\
\hline
\end{tabular}

Terek Sandpipers occupy estuaries and mudflats but at Kunsan they are most commonly seen at the tide line. They seem more numerous during the fall migration. They nest and breed throughout the taiga and steppe latitudes of Asia and winter in southern Asia.

Terek Sandpipers are squat wading birds with short legs and necks. They reach $23 \mathrm{~cm}$ in length. Their squat posture gives them the appearance of waddling along the beach. Their upper parts are grey-brown with darkcentered scapular feathers forming two dark lines on the back. The head and neck are finely streaked leading to unmarked white undersides. Field marks include the conspicuously upturned bill and short orange-yellow legs. 


\section{Wood Sandpiper \\ Tringa glareola}

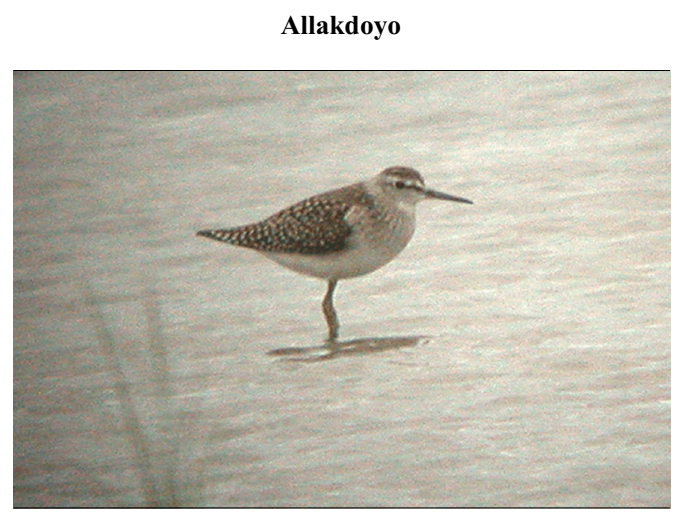

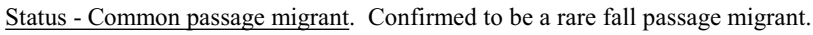

\begin{tabular}{|l|c|c|c|c|c|c|c|c|c|c|c|c|}
\hline \multicolumn{10}{|c|}{ Wood Sandpiper } \\
\hline & Jan & Feb & Mar & Apr & May & Jun & Jul & Aug & Sep & Oct & Nov & Dec \\
\hline Forests & & & & & & & & & & & & \\
\hline Wetlands & & & & & & & & C & R & & & \\
\hline Intertidal Zone & & & & & & & & & & & & \\
\hline Airfield & & & & & & & & R & & & & \\
\hline Cantonment & & & & & & & & & & & & \\
\hline
\end{tabular}

Wood Sandpipers prefer freshwater wetlands. Single individuals were recorded in water-filled tire ruts on the airfield and the small wetland adjacent to the land farm. In these locations, they were observed to be stalking and feeding on small frogs. They nest and breed in the taiga and steppe latitudes of Asia. They overwinter in southern Asia.

Well-camouflaged, they tend to freeze in place when they sense danger. Small, graceful wading birds, they reach only about $20 \mathrm{~cm}$ in length. Their dark upper parts are heavily spotted with buff. The breast and undersides are whitish. Field marks include a prominent whitish eyebrow and in flight, they display pale wing liners, a small white rump patch, and a densely barred tail. 


\section{Grey-tailed Tattler}

Heteroscelus brevipes

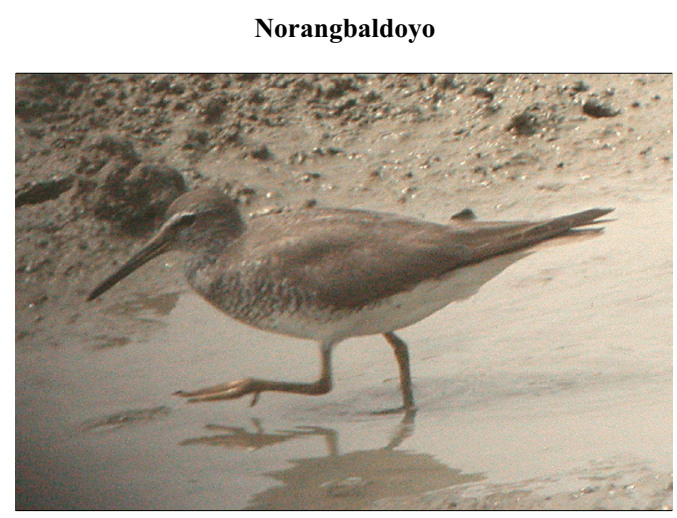

Status - Uncommon passage migrant. Confirmed to be common transients, especially during the fall migration.

\begin{tabular}{|l|c|c|c|c|c|c|c|c|c|c|c|c|}
\hline \multicolumn{10}{|c|}{ Grey-tailed Tattler } \\
\hline & Jan & Feb & M ar & Apr & M ay & Jun & Jul & Aug & Sep & Oct & Nov & Dec \\
\hline Forests & & & & & & & & & & & & \\
\hline Wetlands & & & & & & & & & & & & \\
\hline Intertidal Zone & & & & & U & & & c & c & & & \\
\hline Airfield & & & & & & & & & & & & \\
\hline Cantonment & & & & & & & & & & & & \\
\hline
\end{tabular}

Grey-tailed Tattlers frequent estuaries and mudflats during migration. They often appear along Kunsan's adjacent mudflats in mixed flocks with Terek Sandpipers and Greenshanks. The majority of the tattler population migrates from their wintering grounds in the Southern Hemisphere to breed in northeastern Siberia.

Grey-tailed Tattlers average $25 \mathrm{~cm}$ in length. Their medium grey upper parts are unmarked. The underparts are whitish with fine wavy markings along the flanks. Diagnostic field marks are a whitish eyebrow that meets on the forehead, a dark eyeline, a straight black bill, yellow legs, and dark, unmarked underwings in flight. 


\section{Common Sandpiper}

Actitis hypoleucos

\section{Kkapjakdoyo}

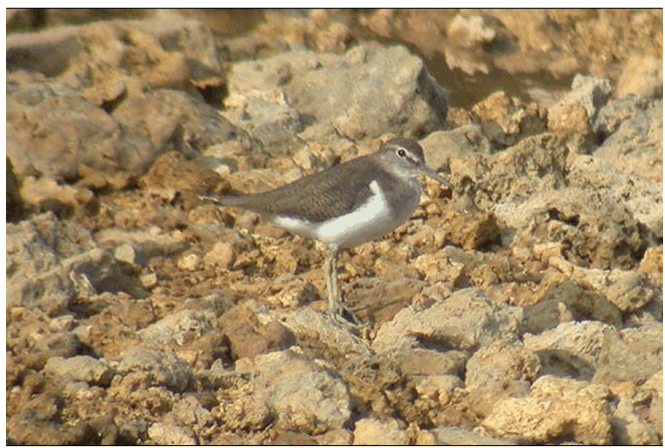

Status - Common summer visitor. Confirmed to be uncommon in late winter and spring, but common in the late summer and fall.

\begin{tabular}{|l|l|l|l|l|l|l|l|l|l|l|l|l|}
\hline \multicolumn{10}{|c|}{ Common Sandpiper } \\
\hline & Jan & Feb & M ar & Apr & M ay & Jun & Jul & Aug & Sep & Oct & Nov & Dec \\
\hline Forests & & & & & & & & & & & & \\
\hline Wetlands & & & & & & & & & & & & \\
\hline Intertidal Zone & & U & R & & U & R & & U & C & & C & \\
\hline Airfield & & & & & & & & & & & & \\
\hline Cantonment & & & & & & & & & & & & \\
\hline
\end{tabular}

Common Sandpipers frequent most wetland habitats including the estuary and mudflats bordering Kunsan. They nest and breed throughout most of northern Asia and overwinter throughout most of southern Asia. They are year-round residents of Japan and it is likely they are year-round residents in the vicinity of Kunsan, also.

Common Sandpipers are relatively small sandpipers reaching only $20 \mathrm{~cm}$ in length. They have a dark brown crown and back with a distinct white eyebrow and unmarked white undersides. Their faces and breasts are brown-streaked. The diagnostic field mark is the white wedge that separates the streaked breast from the curved bend of the wing. On the ground, they constantly bob their tails and appear to teeter. In flight, they show a distinct white wing bar and a dark rump. 


\section{Black-tailed Godwit}

Limosa limosa

\section{Heuk-kkoridoyo}

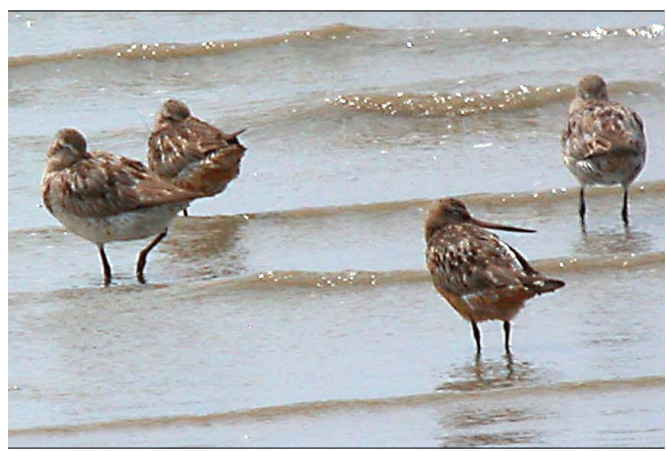

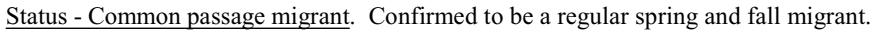

\begin{tabular}{|l|c|c|c|c|c|c|c|c|c|c|c|c|}
\hline \multicolumn{10}{|c|}{ Black-tailed Godwit } \\
\hline & Jan & Feb & M ar & Apr & M ay & Jun & Jul & Aug & Sep & Oct & Nov & Dec \\
\hline Forests & & & & & & & & & & & & \\
\hline Wetlands & & & & & & & & & & & & \\
\hline Intertidal Zone & & & R & C & A & & & C & R & & & \\
\hline Airfield & & & & & & & & & & & & \\
\hline Cantonment & & & & & & & & & & & & \\
\hline
\end{tabular}

Black-tailed Godwits can be found in the rice fields, salt pans, and mudflats adjacent to Kunsan. Gregarious, they often occur in flocks numbering in the thousands during migration. They nest and breed in the lowland grasslands and tundra of Siberia and overwinter in the southern hemisphere of Australasia.

Black-tailed Godwits are large waders often exceeding $40 \mathrm{~cm}$ in length. They have long, straight flesh-colored bills with dark tips. Their breeding plumage is a rich coppery head, neck, and breast over a white belly with black barring on the sides of the breast and belly. In flight, they have a distinct black-and-white pattern with a broad white wing bar and a white tail with a black band at the tip.

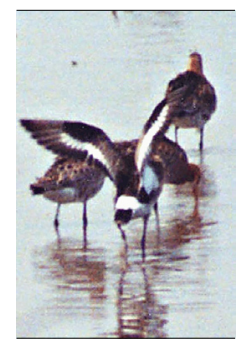




\section{Eurasian Curlew}

Numenius arquata

\section{Madoyo}

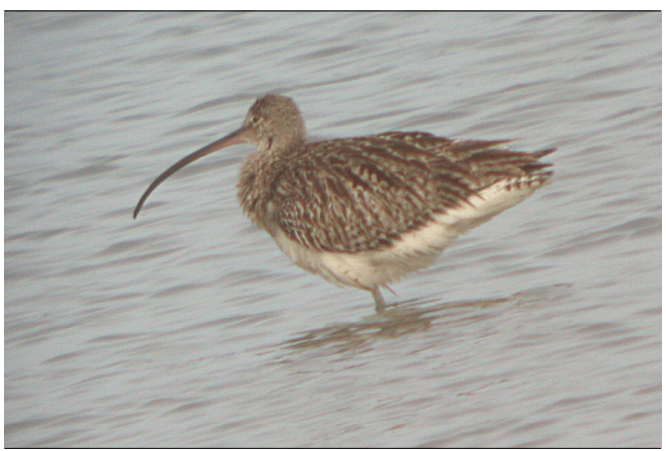

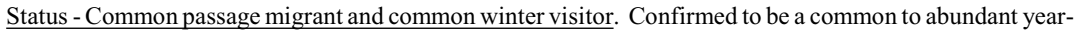
round resident.

\begin{tabular}{|l|c|c|c|c|c|c|c|c|c|c|c|c|}
\hline \multicolumn{10}{|c|}{ Eurasian Curlew } \\
\hline & Jan & Feb & M ar & Apr & M ay & Jun & Jul & Aug & Sep & Oct & Nov & Dec \\
\hline Forests & & & & & & & & & & & & \\
\hline Wetlands & & & & & & & & & & & & \\
\hline Intertidal Zone & R & A & A & C & U & C & U & A & A & U & A & A \\
\hline Airfield & & & & & & & & & & & & \\
\hline Cantonment & & & & & & & & & & & & \\
\hline
\end{tabular}

Large flocks of Eurasian Curlews frequent the mudflats and shell bars adjacent to Kunsan AB. Short-distance migrants, mature adults breed in the upland grasslands and tundra of Siberia and overwinter along the southern Korean and Chinese coasts. Non-breeders are known to remain in their wintering grounds all year.

Eurasian Curlews are large wading birds reaching $58 \mathrm{~cm}$ in length and a wingspan of $2 \mathrm{~m}$. They sport huge, down-curved bills. The head, neck, back, and wings are streaked brown to grey-brown. The belly and vent are generally unstreaked white, but younger birds may be tan. Diagnostic field marks are best seen in flight and include the white lower back, rump, tail, and wings linings.

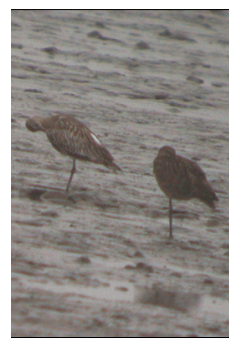


Far Eastern Curlew

Numenius madagascariensis

Allak-kkorimadoyo

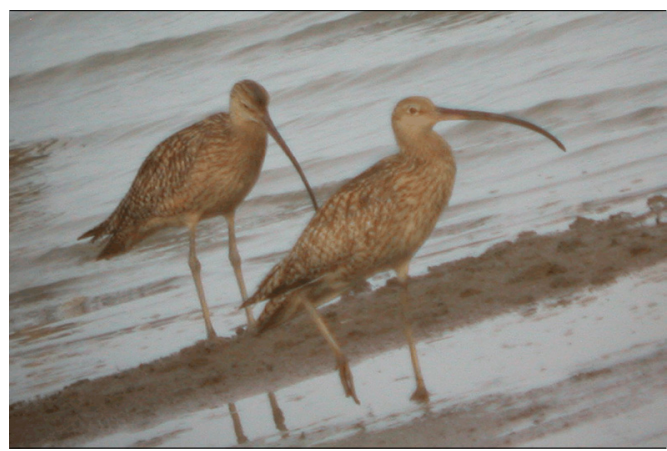

Status - Common passage migrant. Confirmed as a common to abundant summer resident and uncommon during the winter season.

Far Eastern Curlew
\begin{tabular}{|l|c|c|c|c|c|c|c|c|c|c|c|c|}
\hline \multicolumn{10}{|l|}{ Reserved species } \\
\hline & Jan & Feb & Mar & Apr & May & Jun & Jul & Aug & Sep & Oct & Nov & Dec \\
\hline Forests & & & & & & & & & & & & \\
\hline Wetlands & & & & & & & & & & & & \\
\hline Intertidal Zone & & & C & A & & A & C & U & & & U & U \\
\hline Airfield & & & & & & & & & & & & \\
\hline Cantonment & & & & & & & & & & & & \\
\hline
\end{tabular}

Flocks of Far Eastern Curlews occur with Eurasian Curlews on the local mudflats and shell bars. Longdistance migrants, most Far Eastern Curlews overwinter in Australia, migrating through the Philippines and New Guinea. Mature adults breed in bogs and marshes of Siberia. Many non-breeders spend the northern summer in the Kunsan area.

Far Eastern Curlews also are large wading birds $63 \mathrm{~cm}$ in length and having a wingspan of $2 \mathrm{~m}$. They also have huge, down-curved bills. Their plumage is buff-brown streaked with a warm brown. A brown lower back, rump, and tail with dark wings linings are the field marks to distinguish it from the Eurasian Curlew. 


\section{Whimbrel \\ Numenius phaeopus}

\section{Jungburidoyo}

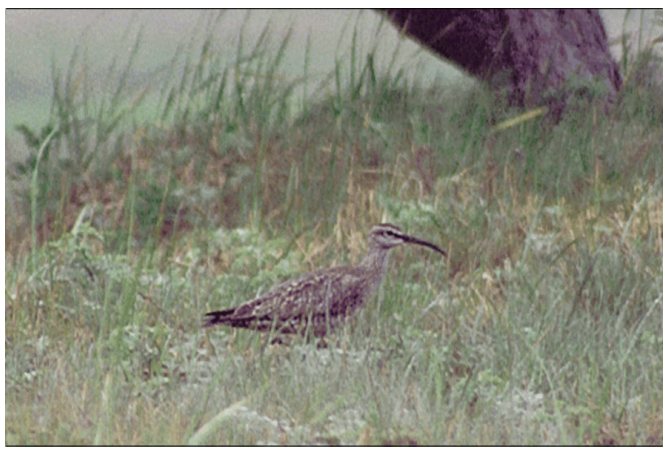

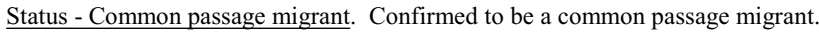

\begin{tabular}{|l|c|c|c|c|c|c|c|c|c|c|c|c|}
\hline \multicolumn{10}{|c|}{ Whimbrel } \\
\hline & Jan & Feb & Mar & Apr & M ay & Jun & Jul & Aug & Sep & Oct & Nov & Dec \\
\hline Forests & & & & & & & & & & & & \\
\hline Wetlands & & & & & & & & & & & & \\
\hline Intertidal Zone & & & & & C & & & C & & & & \\
\hline Airfield & & & & C & A & & & & U & & & \\
\hline Cantonment & & & & C & C & & & & & & & \\
\hline
\end{tabular}

Whimbrels are only present for short periods during the spring and fall migrations. They normally forage in the closely cropped grasslands of the airfield, golf course, and POL-north area. But during the spring of 2005, migrating flocks of 100-120 birds were recorded on the airfield and also on the mudflats. The Asian populations nest and breed in the Siberian tundra and overwinter in southeastern Asia and Australasia.

Whimbrels are small curlews averaging $43 \mathrm{~cm}$ in length. They are dark brown with patterns of streaks on their upper parts and barring underneath. They have a long, decurved bill, a conspicuous white eyebrow, and a dark cap with a medial white stripe. In flight, the Whimbrel displays a light or whitish rump patch. 


\section{Common Snipe}

Gallinago gallinago

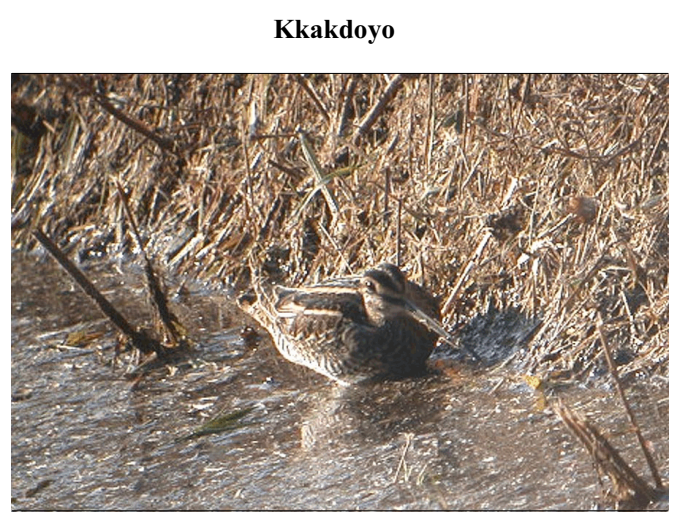

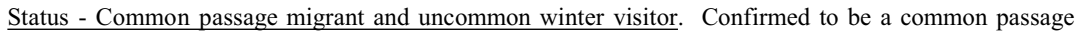
migrant.

\begin{tabular}{|l|c|c|c|c|c|c|c|c|c|c|c|c|}
\hline \multicolumn{10}{|c|}{ Common Snipe } \\
\hline & Jan & Feb & M ar & Apr & M ay & Jun & Jul & Aug & Sep & Oct & Nov & Dec \\
\hline Forests & & & & & & & & & & & & \\
\hline Wetlands & & & U & U & & & & C & C & & R & \\
\hline Intertidal Zone & & & & & & & & & & & & \\
\hline Airfield & & & & & & & & C & & & U & \\
\hline Cantonment & & & & & & & & & & & & \\
\hline
\end{tabular}

Common Snipe prefer freshwater wetland habitats. On base, they occur in the small wetland near the land farm, the Perimeter Road drainage ditches, and the airfield's ditches and water-filled tire ruts. They characteristically explode from cover with a harsh call and fly rapidly in a zig-zag pattern. Common Snipe nest and breed throughout northern Asia and overwinter southward from southern South Korea.

The Common Snipe is relatively small, reaching only about $26 \mathrm{~cm}$ in length. They are usually not seen until flushed from cover. In flight, the best field mark is the white trailing edge of the wing along with a dark-and-white underwing pattern. Some snipes on base display different behavior and calls when flushed. But to date, field identification has not been confirmed to be other than the Common Snipe.

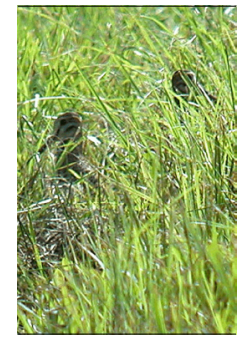




\section{Eurasian Woodcock \\ Scolopax rusticola}

\section{Metdoyo}

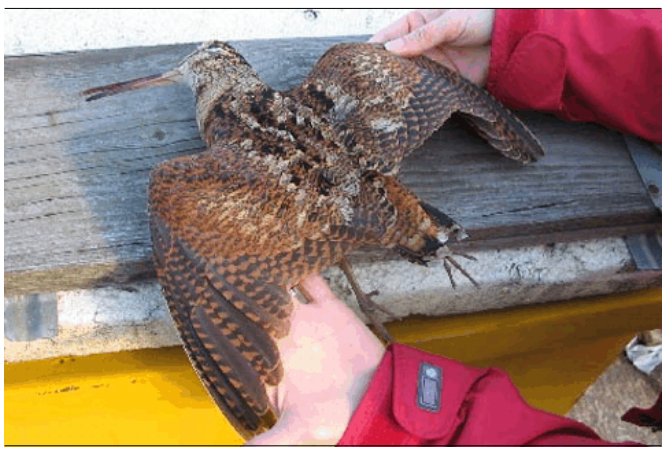

Status - Uncommon passage migrant. Confirmed by Peter Nebel on January 6, 2004.

\begin{tabular}{|l|c|c|c|c|c|c|c|c|c|c|c|c|}
\hline \multicolumn{10}{|c|}{ Eurasian Woodcock } \\
\hline & Jan & Feb & M ar & Apr & M ay & Jun & Jul & Aug & Sep & Oct & Nov & Dec \\
\hline Forests & & & & & & & & & & & & \\
\hline Wetlands & R & & & & & & & & & & & \\
\hline Intertidal Zone & & & & & & & & & & & & \\
\hline Airfield & & & & & & & & & & & & \\
\hline Cantonment & & & & & & & & & & & & \\
\hline
\end{tabular}

A dead Eurasian Woodcock was recovered next to the Perimeter Road in front of the Patriot Battery on the east side of the airfield. This is an unusual record because Eurasian Woodcocks prefer forested wetlands and stream sides. They are primarily nocturnal and stay on the ground during the day. Migration occurs at night. They overwinter very close to the persistent frost line. Winter movements appear to be tied to fluctuations in the frost line. They nest and breed throughout the northern, broad-leaved deciduous forests of northern Japan and Siberia.

Eurasian Woodcocks average $34 \mathrm{~cm}$ in length and are larger than snipes. They are well-camouflaged and are only seen when flushed from cover. They are reddish-brown in overall coloration with distinct, black transverse bars on the back of the head. (Eurasian Woodcock photographed by Peter Nebel.) 


\section{Oriental Pratincole}

Glareola maldivarum

\section{Jebimulttesae}

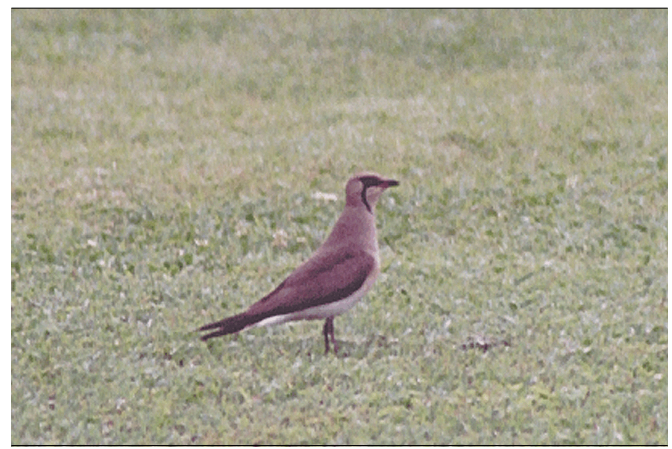

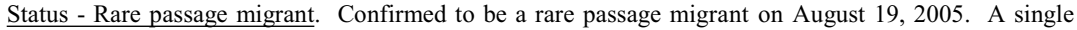
Oriental Pratincole was sighted on the shell bar about $200 \mathrm{~m}$ west of the sea wall during the ebbing tide with a large flock of Black-tailed Gulls, curlews (both species), Ruddy Turnstones, Grey-tailed Tattlers, and Black-tailed Godwits.

\begin{tabular}{|l|c|c|c|c|c|c|c|c|c|c|c|c|}
\hline \multicolumn{10}{|c|}{ Oriental Pratincole } \\
\hline & Jan & Feb & M ar & Apr & M ay & Jun & Jul & Aug & Sep & Oct & Nov & Dec \\
\hline Forests & & & & & & & & & & & & \\
\hline Wetlands & & & & & & & & & & & & \\
\hline Intertidal Zone & & & & & & & & R & & & & \\
\hline Airfield & & & & & & & & & & & & \\
\hline Cantonment & & & & & & & & & & & & \\
\hline
\end{tabular}

They prefer riverbank and dry grassland habitats, but are also known to occur in reclaimed land. Insectivores, they hunt and feed in flight. They spend their summers throughout eastern China and winter in southeastern Asia.

Pratincoles are medium-sized birds reaching about $25 \mathrm{~cm}$ in length. They are generally brown in color, dark on top, and light beneath with a creamy-colored throat bordered with a black line. They stand in an upright posture and their folded wings extend beyond the tip of their tail. In flight, they display a bold white rump, dark underwings with chestnut-colored linings, and a deeply forked tail. Their flight is swallow-like with slow wing beats. (Oriental Pratincole photographed at Kadena AB.) 


\section{Black-tailed Gull}

\section{Larus crassirostris}

\section{Gwaengigalmaegi}

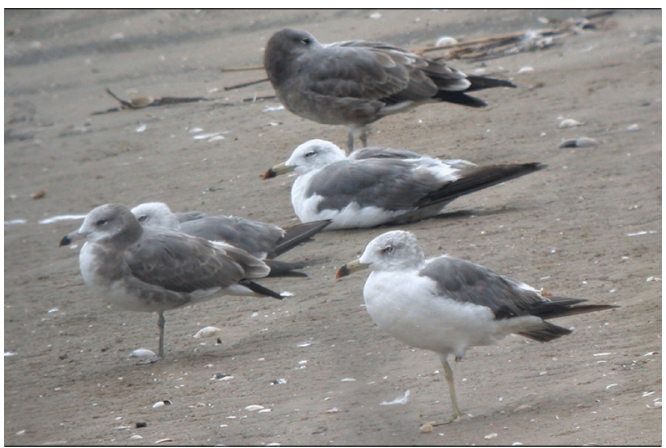

Status - Abundant resident. Confirmed to be an abundant resident, especially during the breeding season.

\begin{tabular}{|l|c|c|c|c|c|c|c|c|c|c|c|c|}
\hline \multicolumn{10}{|c|}{ Black-tailed Gull } \\
\hline & Jan & Feb & M ar & Apr & M ay & Jun & Jul & Aug & Sep & Oct & Nov & Dec \\
\hline Forests & & & & & & & & & & & & \\
\hline Wetlands & & & & & & & & & & & & \\
\hline Intertidal Zone & U & C & U & & A & A & A & A & A & C & A & U \\
\hline Airfield & & & & & & & & & & & & \\
\hline Cantonment & & & & & & & & & & & & \\
\hline
\end{tabular}

Black-tailed Gulls are year-round residents along Korea's coasts. Although not migratory, there is some seasonal movement to slightly warmer areas. There is a notable reduction in local numbers during the winter when they are displaced by Herring Gulls.

Black-tailed Gulls are medium-sized gulls averaging $47 \mathrm{~cm}$ in length with a wingspan of $1.2 \mathrm{~m}$. Adults have a medium grey back with an unmarked white breast and undersides. Field marks include a red-tipped yellow bill with subterminal black band, yellow legs, yellow iris, brown streaked head, and a black subterminal band on an otherwise white tail and rump. As with most gulls, firstand second-year juveniles have different plumage than the adults - generally brown streaked with pink legs and bill and lack the red spot at the tip of the bill.

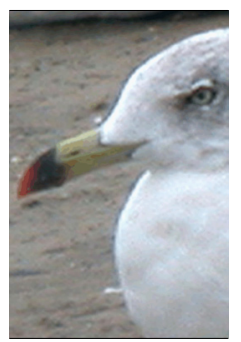




\section{Black-headed Gull}

Larus ridibundus

\section{Bulgeunburigalmaegi}

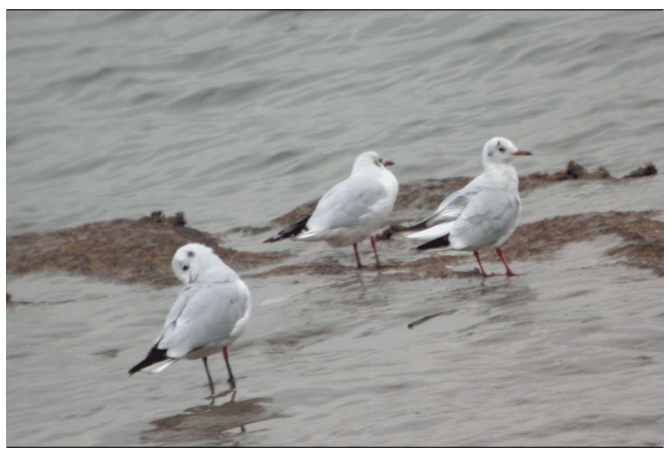

Status - Common winter visitor. Confirmed to be an uncommon to rare winter visitor near base but common along the Geum River estuary.

\begin{tabular}{|l|c|c|c|c|c|c|c|c|c|c|c|c|}
\hline \multicolumn{10}{|c|}{ Black-headed Gull } \\
\hline & Jan & Feb & M ar & Apr & M ay & Jun & Jul & Aug & Sep & Oct & Nov & Dec \\
\hline Forests & & & & & & & & & & & & \\
\hline Wetlands & & & & & & & & & & & & \\
\hline Intertidal Zone & & R & & & & U & & & & & & \\
\hline Airfield & & & & & & & & & & & & \\
\hline Cantonment & & & & & & & & & & & & \\
\hline
\end{tabular}

Black-headed Gulls prefer estuarine and marine coasts of Korea during the winter months. They migrate north to Siberia and the Kamchatka Peninsula during the breeding season.

Black-headed Gulls are small- to medium-sized gulls attaining $41 \mathrm{~cm}$ in length. As their name suggests, they have black heads during the breeding season, but when they are in the vicinity of Kunsan during the non-breeding season, their heads are white with an obvious black "ear patch." Good field marks in the winter are a black-tipped red bill and red legs. In flight, they have pale grey upper wings with a white leading edge and black-tipped primary wing tips.

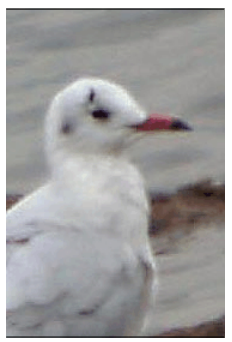




\section{Herring Gull}

Larus argentatus

\section{Jaegalmaegi}

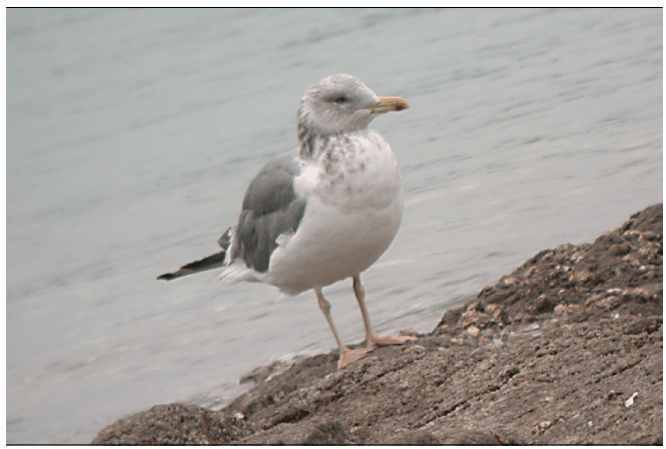

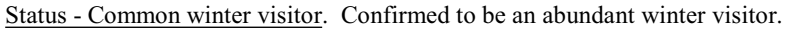

\begin{tabular}{|l|c|c|c|c|c|c|c|c|c|c|c|c|}
\hline \multicolumn{10}{|c|}{ Herring Gull } \\
\hline & Jan & Feb & Mar & Apr & May & Jun & Jul & Aug & Sep & Oct & Nov & Dec \\
\hline Forests & & & & & & & & & & & & \\
\hline Wetlands & & & & & & & & & & & & \\
\hline Intertidal Zone & A & A & A & A & & & & & & U & U & A \\
\hline Airfield & & & & & & & & & & & & \\
\hline Cantonment & & & & & & & & & & & & \\
\hline
\end{tabular}

The Herring Gull is the same species that is common to much of North America. At Kunsan, the Herring Gull replaces the Black-tailed Gull during the winter months. Then in the summer, the Herring Gulls migrate to the Arctic tundra to nest and breed and the Black-tailed Gulls become the predominant gull species.

Herring Gulls are large gulls averaging $62 \mathrm{~cm}$ in length with a wingspan of $1.4 \mathrm{~m}$. Adults have a medium grey back with a brown-streaked white head and breast, and an unmarked white belly and vent. Field marks include a yellow bill with a red spot on the lower mandible, pink legs, yellow iris, and a white tail and rump. First- and second-year juveniles have plumage that is generally brown streaked with pink legs and a black bill.

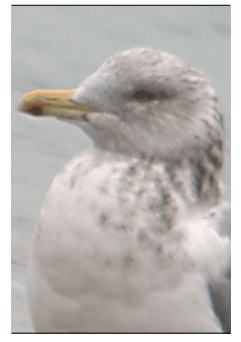




\section{Slaty-backed Gull}

Larus schistisagus

Keunjaegalmaegi

Not

Photographed

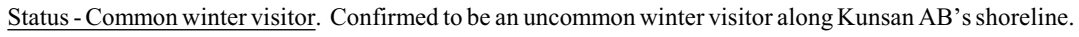

\begin{tabular}{|l|c|c|c|c|c|c|c|c|c|c|c|c|}
\hline \multicolumn{10}{|c|}{ Slaty-backed Gull } \\
\hline & Jan & Feb & M ar & Apr & May & Jun & Jul & Aug & Sep & Oct & Nov & Dec \\
\hline Forests & & & & & & & & & & & & \\
\hline Wetlands & & & & & & & & & & & & \\
\hline Intertidal Zone & U & U & & U & & & & & & & & U \\
\hline Airfield & & & & & & & & & & & & \\
\hline Cantonment & & & & & & & & & & & & \\
\hline
\end{tabular}

During the winter months, there always appears to be a few Slaty-backed Gulls mixed in with the huge flocks of Herring Gulls. They stand out clearly because their backs appear to be black from a distance. Slatybacked Gulls winter along the coasts of China, Korea, and Japan. They are reported to be more common along Korea's eastern coast. They nest and breed along the shores of the East Sea, Sea of Okhotsk, and the Bering Sea.

Slaty-backed Gulls are large gulls averaging $64 \mathrm{~cm}$ in length. Field marks include their dark grey back and wings that contrast little with the black wingtips. Like the Herring Gull, the bill is yellow with a red spot on the lower mandible, the iris is yellow, the legs are pink, and the tail is white. 


\section{Little Tern \\ Sterna albifrons}

\section{Soejebigalmaegi}

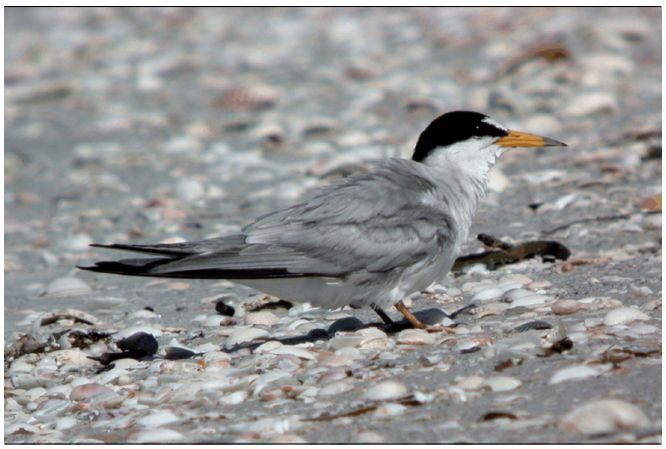

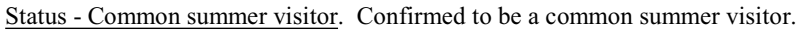

\begin{tabular}{|l|c|c|c|c|c|c|c|c|c|c|c|c|}
\hline \multicolumn{10}{|c|}{ Little Tern } \\
\hline & Jan & Feb & Mar & Apr & May & Jun & Jul & Aug & Sep & Oct & Nov & Dec \\
\hline Forests & & & & & & & & & & & & \\
\hline Wetlands & & & & & & & & & & & & \\
\hline Intertidal Zone & & & & & C & C & & C & & & & \\
\hline Airfield & & & & & & & & & & & & \\
\hline Cantonment & & & & & & & & & & & & \\
\hline
\end{tabular}

The Little Tern is the same species as the North American Least Tern. They nest and breed throughout Korea, Japan, and China. They spend the non-breeding season in the Philippines, Malaysia, and Australasia.

The Little Tern is a small tern reaching only $24 \mathrm{~cm}$ in length. They have a medium grey back with unmarked white undersides. Field marks include a black eye line and cap leaving a white forehead, yellow legs, and a yellow bill with a black tip. Their forked tail is evident when hovering and diving along the tide line. (Little Terns photographed at Kadena AB.)

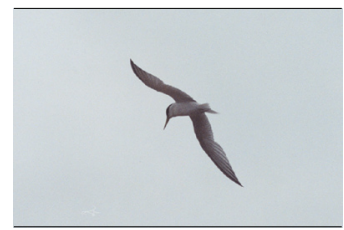




\section{Rock Dove}

Columba livia

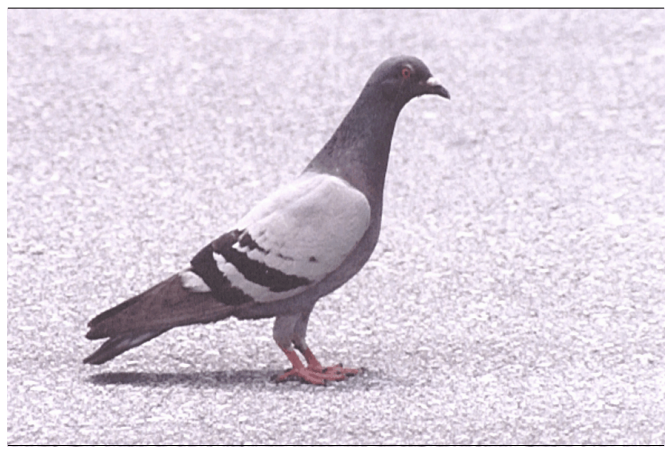

Status - Not described by Lee et al. (2000). Confirmed on February 25, 2004. Although common in Kunsan City and some villages near the base, only one individual has been recorded to date on the base.

\begin{tabular}{|l|l|l|l|l|l|l|l|l|l|l|l|l|}
\hline \multicolumn{10}{|c|}{ Rock Dove } \\
\hline & Jan & Feb & M ar & Apr & M ay & Jun & Jul & Aug & Sep & Oct & Nov & Dec \\
\hline Forests & & & & & & & & & & & & \\
\hline Wetlands & & & & & & & & & & & & \\
\hline Intertidal Zone & & & & & & & & & & & & \\
\hline Airfield & & & & & & & & & & & & \\
\hline Cantonment & & R & & & & & & & & & & \\
\hline
\end{tabular}

Rock Doves are common worldwide. Rock Doves are commonly referred to as city pigeons. They feed during the day in city parks and open fields. They roost and nest on window ledges, bridges, barns, and other out buildings. They do not migrate.

They are highly variable in coloration as the result of centuries of near domestication. Individual birds most closely resembling their wild ancestors have a neck and head darker than their backs with black bars on the inner wing, like the individual pictured above. Their legs and eyes are typically red. 


\section{Rufous Turtle Dove}

Streptopelia orientalis

\section{Metbidulgi}

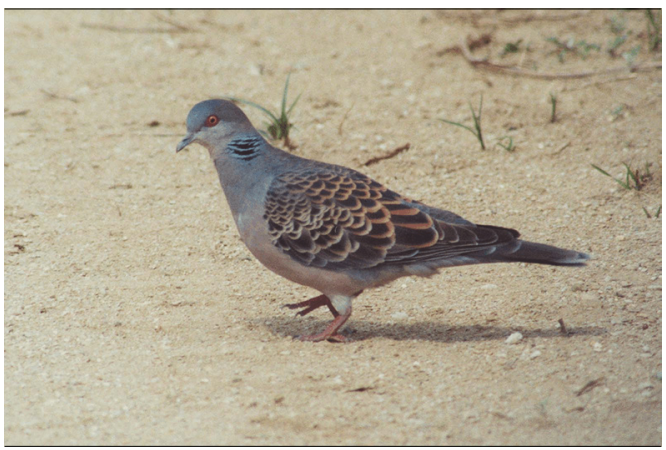

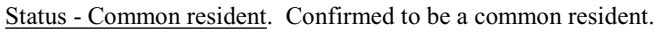

\begin{tabular}{|l|c|c|c|c|c|c|c|c|c|c|c|c|}
\hline \multicolumn{10}{|c|}{ Rufous Turtle Dove } \\
\hline & Jan & Feb & M ar & Apr & M ay & Jun & Jul & Aug & Sep & Oct & Nov & Dec \\
\hline Forests & C & A & A & C & A & C & C & C & A & A & C & A \\
\hline Wetlands & & & & & & & & & & & & \\
\hline Intertidal Zone & & & & & & & & & & & & \\
\hline Airfield & & C & U & C & C & C & & C & C & C & C & C \\
\hline Cantonment & C & C & C & C & C & C & C & C & C & C & C & C \\
\hline
\end{tabular}

The Rufous Turtle Dove is probably the most common bird on Kunsan AB. They are common in parks, gardens, residential areas, and forest edges. On Kunsan, the local populations are present all year round and occupy all but the wetlands and intertidal zones. However, during the winter months, population sizes appear to swell with an influx of birds that nest and breed in northern Asia. They prefer conifers for nesting. Nests sites are numerous in the POL-north area and Wolf Pack Park.

Their heads, necks, and underparts are brownish to pinkish grey with an obvious black-and-grey striped patch on the side of the neck. The back and scapulars are blackish brown with rufous edges. The legs and iris are dark red. 


\section{Common Cuckoo}

\section{Cuculus canorus}

\section{Ppeokkugi}

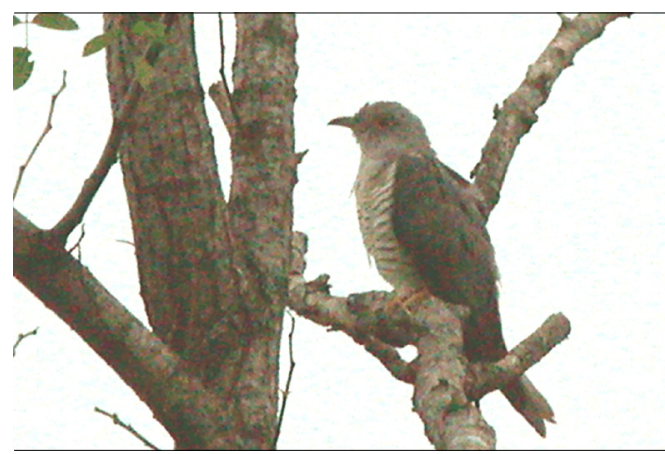

Status - Common summer visitor. Confirmed to be a common summer visitor.

\begin{tabular}{|l|c|c|c|c|c|c|c|c|c|c|c|c|}
\hline \multicolumn{10}{|c|}{ Common Cuckoo } \\
\hline & Jan & Feb & M ar & Apr & M ay & Jun & Jul & Aug & Sep & Oct & Nov & Dec \\
\hline Forests & & & & & C & C & & & & & & \\
\hline Wetlands & & & & & & & & & & & & \\
\hline Intertidal Zone & & & & & & & & & & & & \\
\hline Airfield & & & & & & U & & & & & & \\
\hline Cantonment & & & & & U & U & & & & & & \\
\hline
\end{tabular}

The Common Cuckoo prefers the edges of woodlands, open land with scattered trees including wetlands and cultivated fields. They often perch in the open to declare their territory with the unmistakable "Cuc-koo" call. Cuckoos are nest parasites. They lay their eggs in the nests of other, usually smaller bird species. The young cuckoos are raised by the host species, often at the expense of their own chicks.

Three other species of cuckoos are almost indistinguishable from the Common Cuckoo in the field, especially the Oriental Cuckoo. The diagnostic characteristic is the call. None of the other species have a similar call. The Common Cuckoo is approximately $35 \mathrm{~cm}$ in length with a grey head, back, scapulars, breast, and tail. The belly and vent are whitish with fine grey barring - Indian and Little Cuckoos have thick bold barring. The bright yellow eye ring and iris further differentiate them from the Indian Cuckoo. 


\section{Brown Hawk Owl}

Ninox scutulata

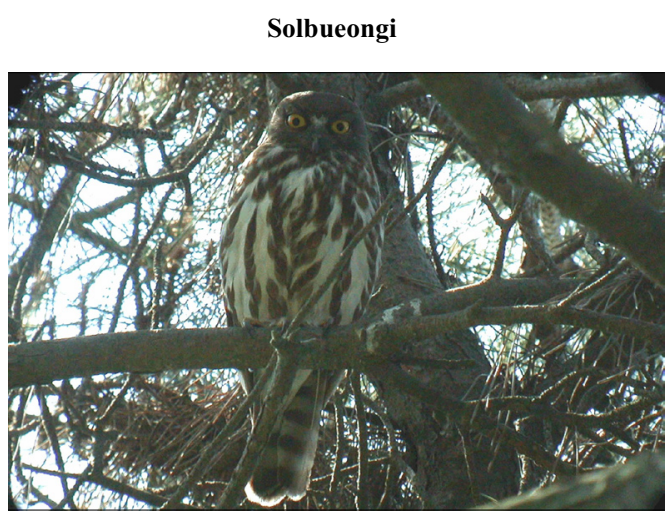

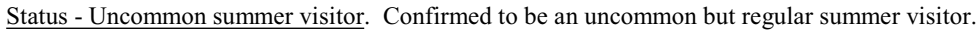

" Cultural Property No. 324

\begin{tabular}{|l|c|c|c|c|c|c|c|c|c|c|c|c|}
\hline \multicolumn{10}{|c|}{ Brown Hawk Owl } \\
\hline & Jan & Feb & Mar & Apr & May & Jun & Jul & Aug & Sep & Oct & Nov & Dec \\
\hline Forests & & & & & U & U & & & & & & \\
\hline Wetlands & & & & & & & & & & & & \\
\hline Intertidal Zone & & & & & & & & & & & & \\
\hline Airfield & & & & & & & & & & & & \\
\hline Cantonment & & & & & U & & & & & & & \\
\hline
\end{tabular}

Brown Hawk Owls prefer coastal conifer belts, lowland wooded areas with tall trees, and wooded parks or gardens. It is not surprising to find them in the POL-north area where it is likely that they nest and breed. Their breeding season is from late May through late July. They nest in naturally occurring tree cavities. Although they appear to migrate in the Kunsan area, they are year-round residents along the southern tip of the Korean Peninsula.

Brown Hawk Owls reach $29 \mathrm{~cm}$ in length and differ greatly in appearance from other owls. They do not have facial disks or ear tufts so typical of other owls. They have chocolate-brown heads, back, wings, and tails. The underparts are white with bold brown streaks. The underside of the tail is also white with black bars. Other field marks include a white wedge between their intense yellow eyes. 


\section{Jungle Nightjar \\ Caprimulgus indicus}

\section{Ssokdoksae}

\section{Not \\ Photographed}

Status - Common summer visitor. Confirmed to be an uncommon to rare summer visitor when flushed from immature pine stands on the slopes of Little Coyote Hill during the habitat delineations conducted in May 1998. They were not recorded again until June 22, 2002, and then were apparently absent despite numerous survey efforts at dusk at the base of Little Coyote Hill. Most recently, a dead specimen was recovered by Peter Nebel on September 7, 2005, at the base of Water Tower Hill.

\begin{tabular}{|l|c|c|c|c|c|c|c|c|c|c|c|c|}
\hline \multicolumn{10}{|c|}{ Jungle Nightjar } \\
\hline & Jan & Feb & Mar & Apr & M ay & Jun & Jul & Aug & Sep & Oct & Nov & Dec \\
\hline Forests & & & & & U & U & & & & & & \\
\hline Wetlands & & & & & & & & & & & & \\
\hline Intertidal Zone & & & & & & & & & & & & \\
\hline Airfield & & & & & & & & & & & & \\
\hline Cantonment & & & & & & & & & R & & & \\
\hline
\end{tabular}

Jungle Nightjars are related to the nighthawks of North America. They prefer open forests and clearings on hillsides. They are nocturnal insect eaters and have well-developed whiskers and a huge gape for capturing insects on the wing. Well-camouflaged, they roost motionless on the ground or along horizontal branches during the day.

Jungle Nightjars reach $29 \mathrm{~cm}$ in length. Their plumage is mottled in brown, buff, black, and grey. They have large eyes, long wings and tails, and tiny bills. In flight, Nightjars appear to be uniformly dark with conspicuous white patches near the wing tips. 


\section{Black-capped Kingfisher \\ Halcyon pileata}

\section{Cheonghobansae}

\section{Not \\ Photographed}

Status - Common summer visitor. Confirmed to be a rare passage migrant.

\section{Black-capped Kingfisher}

\begin{tabular}{|l|l|l|l|l|l|l|l|l|l|l|l|l|}
\hline & Jan & Feb & M ar & Apr & M ay & Jun & Jul & Aug & Sep & Oct & Nov & Dec \\
\hline Forests & & & & & R & & & & & & & \\
\hline Wetlands & & & & & & & & & & & & \\
\hline Intertidal Zone & & & & & & & & & & & & \\
\hline Airfield & & & & & R & & & & R & & & \\
\hline Cantonment & & & & & & & & & & & & \\
\hline
\end{tabular}

Black-capped Kingfishers prefer wooded streams, rice paddies, and coastal areas. At Kunsan, they have been sighted on three occasions during the avian surveys: twice near the center most drainage ditch outfall at the seawall and once in the POL-north area. In each case, the birds were seen only once. It is presumed they were in migration. Korea and northern China are the northern extent of their breeding range. They are present all year round in southern China, but the majority overwinter in southeastern Asia and Malaysia.

Black-capped Kingfishers are medium-sized kingfishers ( $29 \mathrm{~cm}$ in length) with striking plumage. They are unmistakable with their black cap, white throat, collar, and upper breast. Their backs, wings, and tail are a brilliant purplish-blue. Their underparts are rufous. Additional field marks include a bright red oversized bill and legs. In flight, large white wing patches contrast with black wing tips. 


\title{
Common Kingfisher
}

\author{
Alcedo atthis
}

Mulchongsae

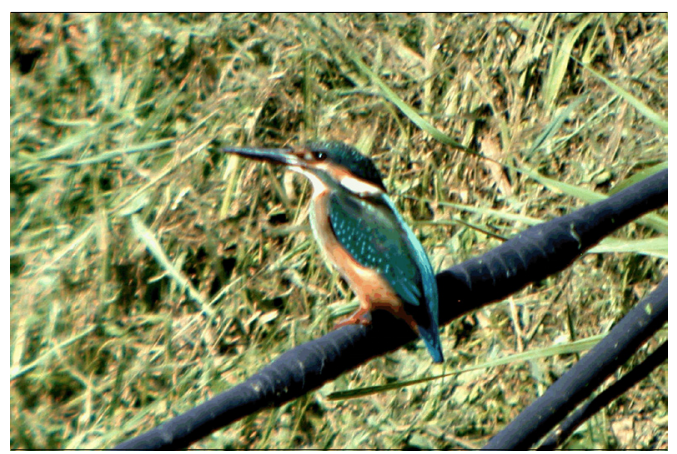

Status - Common summer visitor. Confirmed to be an uncommon summer visitor.

\begin{tabular}{|l|l|l|l|l|l|l|l|l|l|l|l|l|}
\hline \multicolumn{10}{|c|}{ Common Kingfisher } \\
\hline & Jan & Feb & M ar & Apr & M ay & Jun & Jul & Aug & Sep & Oct & Nov & Dec \\
\hline Forests & & & & & & & & & & & & \\
\hline Wetlands & & & & & & & & U & & & & \\
\hline Intertidal Zone & & & & & & & & & & & & \\
\hline Airfield & & & & & & & & & & & & \\
\hline Cantonment & & & & & & & & & & & & \\
\hline
\end{tabular}

The Common Kingfisher is common throughout Korea near quiet freshwater streams, rivers, or ponds where they perch above the water to detect small fish on which they prey. On Kunsan, suitable habitats are the golf course ponds and the drainage ditch that traverses the $\mathrm{CE}$ bulk storage yard. The Common Kingfisher was recorded in August 2005 in the latter location. It is also possible that they visit the golf course ponds during periods of low human activity.

The Common Kingfisher is a brilliantly colored small bird reaching only $17 \mathrm{~cm}$ in length. Their upperparts are an iridescent green-blue with bright aqua blue spots. Most striking is the brilliant aqua-blue back and rump especially visible during flight. Their lores, cheeks, and underparts are a bright orange, which contrast with a white throat and neck patch. The legs are red, and the bill is black. 


\section{Broad-billed Roller \\ Eurystomas orientalis}

\section{Parangsae}

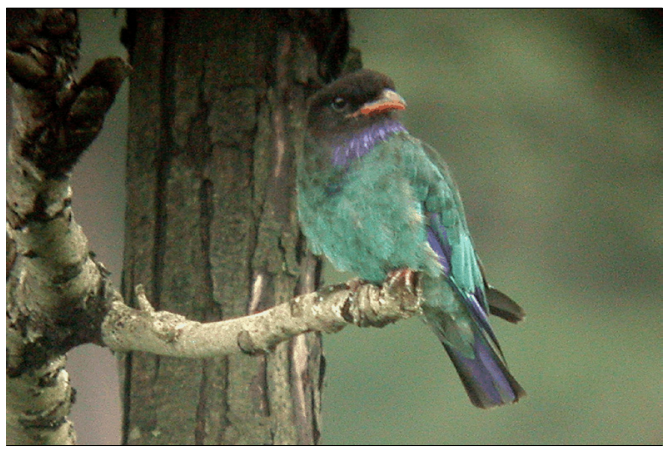

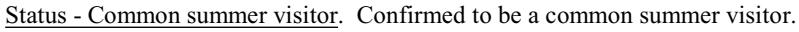

\begin{tabular}{|l|c|c|c|c|c|c|c|c|c|c|c|c|}
\hline \multicolumn{10}{|c|}{ Broad-billed Roller } \\
\hline & Jan & Feb & M ar & Apr & May & Jun & Jul & Aug & Sep & Oct & Nov & Dec \\
\hline Forests & & & & & U & & & C & & & & \\
\hline Wetlands & & & & & & & & & & & & \\
\hline Intertidal Zone & & & & & & & & & & & & \\
\hline Airfield & & & & & & C & & & & & & \\
\hline Cantonment & & & & & & C & & & & & & \\
\hline
\end{tabular}

Broad-billed Rollers prefer forest edges. They are most commonly observed perched on electric poles and overhead wires to pursue and capture insects in flight. Like a large flycatcher, they prey on large aerial insects like long-horned beetles and cicadas.

They appear to prefer two areas on Kunsan: the roadway leading up Little Coyote Hill and the wooded edges of the POL-north area. In May 2005, a pair of Rollers were observed performing their spectacular courtship flights in the POL-north area and adjacent Wolf Pack Park. The turning, swooping, and rolling demonstrated during these courtship displays have led to their common name "roller."

Broad-billed Rollers are stocky birds reaching nearly $30 \mathrm{~cm}$ in length. Their large, flat heads are grey, and their bodies are blue-green. Their throats and the edges of their wings are blue. Field marks are the prominent red bill and in flight, the large white patches on the base of the primaries. 


\section{Hoopoe \\ Upopa epops}

\section{Hututi}

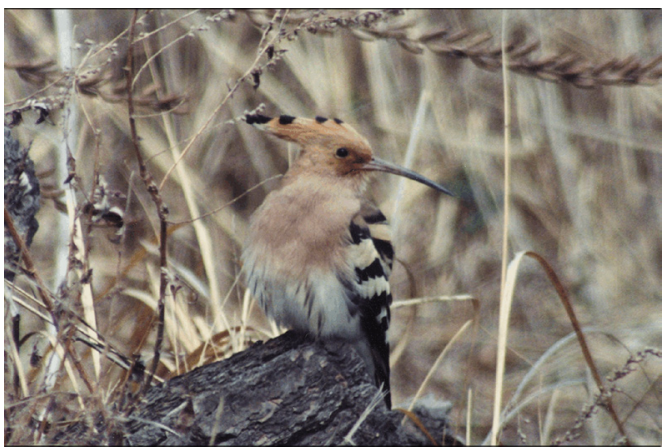

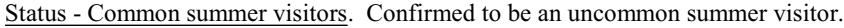

\begin{tabular}{|l|c|c|c|c|c|c|c|c|c|c|c|c|}
\hline \multicolumn{10}{|c|}{ Hoopoe } \\
\hline & Jan & Feb & Mar & Apr & May & Jun & Jul & Aug & Sep & Oct & Nov & Dec \\
\hline Forests & & & & & & & & & & & & \\
\hline Wetlands & & & & & & & & & & & & \\
\hline Intertidal Zone & & & & & & & & & & & & \\
\hline Airfield & & & U & & U & U & & & & & & \\
\hline Cantonment & & & U & & & U & & U & & & & \\
\hline
\end{tabular}

Hoopoes are native to much of Europe, Africa, and Asia. In eastern Asia, they are year-round residents from central China, southward. However some, including those of Korea, migrate as far north as southern Siberia to nest and breed. They prefer upland habitats like cultivated fields, lawns, and open woodlands, where they forage for insects.

Hoopoes are the only species in the family Upupidae. Hoopoes attain a length of $28 \mathrm{~cm}$. No other bird resembles them. The sexes are similar each having pinkishbrown plumage with boldly barred black-and-white wings and tail and a long decurved black bill. Most unusual is their black-tipped, erectile crest that resembles a large fan, but is often held flat.

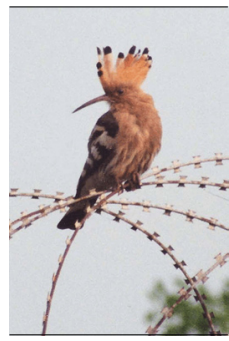




\section{Great Spotted Woodpecker \\ Dendrocopos major}

\section{Osaekttakttaguri}

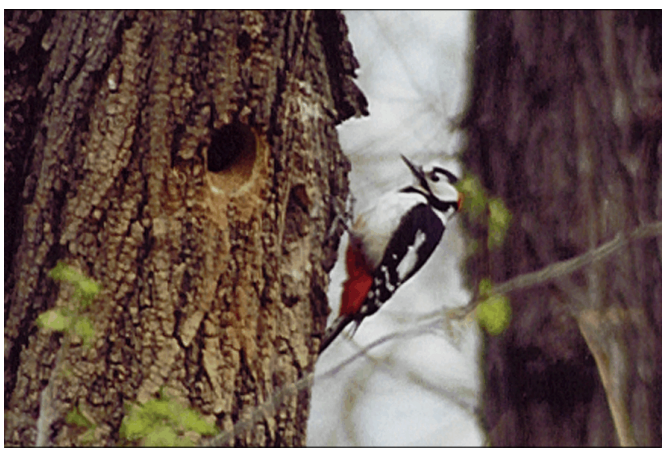

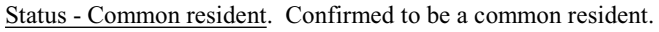

\begin{tabular}{|l|c|c|c|c|c|c|c|c|c|c|c|c|}
\hline \multicolumn{10}{|c|}{ Great Spotted Woodpecker } \\
\hline & Jan & Feb & M ar & Apr & M ay & Jun & Jul & Aug & Sep & Oct & Nov & Dec \\
\hline Forests & & U & & & & & & C & & & U & \\
\hline Wetlands & & & & & & & & & & & & \\
\hline Intertidal Zone & & & & & & & & & & & & \\
\hline Airfield & & & & & & & & & & & & \\
\hline Cantonment & & u & C & & & c & & & c & c & c & \\
\hline
\end{tabular}

Great Spotted Woodpeckers are the most common woodpecker in Korea. They prefer deciduous wooded areas. They are non-migratory and although they are sometimes difficult to locate, they are present on and around Kunsan all year round. They nest in cavities they excavate in living trees.

Both sexes of the Great Spotted Woodpecker have predominantly black-and-white plumage with white barring on black wings. The breast is white, but the lower belly and vent area are bright red. They have a black cap, neck ring, and moustache line surrounding an otherwise white face. Males sport a red crown - females do not. The diagnostic field marks are the large white patches on the scapulars of both sexes in flight and at rest.

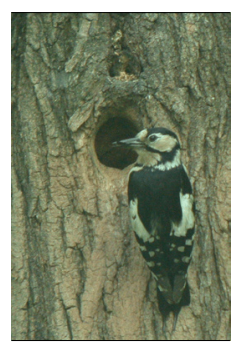




\section{Grey-headed Woodpecker}

Picus canus

\section{Cheongttakttaguri}

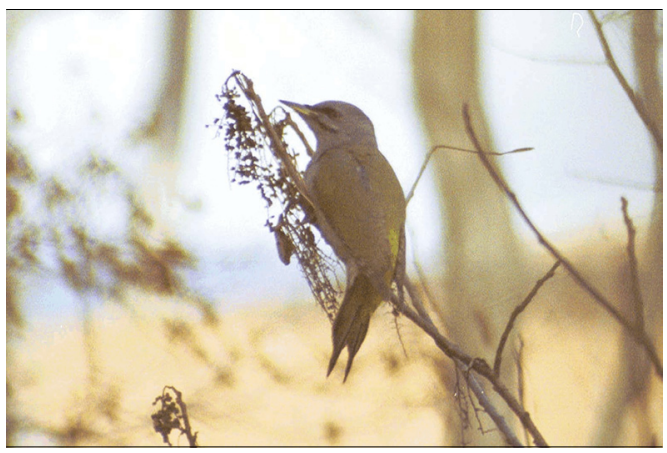

Status - Common resident. Confirmed to be an uncommon resident.

\begin{tabular}{|l|c|c|c|c|c|c|c|c|c|c|c|c|}
\hline \multicolumn{10}{|c|}{ Grey-headed Woodpecker } \\
\hline & Jan & Feb & M ar & Apr & M ay & Jun & Jul & Aug & Sep & Oct & Nov & Dec \\
\hline Forests & & & & & & & & & U & & U & U \\
\hline Wetlands & & & & & & & & & & & & \\
\hline Intertidal Zone & & & & & & & & & & & & \\
\hline Airfield & & & & & & & & & U & & U & \\
\hline Cantonment & & U & & & & & & & & & U & \\
\hline
\end{tabular}

Grey-headed Woodpeckers prefer deciduous wooded mountain slopes and are absent from Kunsan during the breeding season. They typically descend to deciduous lowland areas during the non-breeding season when they appear on Kunsan AB. Although they have seasonal changes in habitat, they are non-migratory. Unlike most other woodpeckers, Grey-headed Woodpeckers often feed on the ground. They also forage over the surfaces of tree trunks and glean insects and spiders from branches and leaves.

The sexes of the Grey-headed Woodpecker are very similar. Both have olive-green backs and scapulars over pale greenish-grey, unmarked underparts. As their name implies, both have a grey head and nape with some dark streaking. The male has a crimson red forehead and dark moustachial stripe - the female lacks the red forehead and has only a pale moustache. In flight, the upper primary wing feathers are dark with white spots and the rump appears golden. 


\section{Eurasian Skylark}

Alauda arvensis

\section{Jongdari}

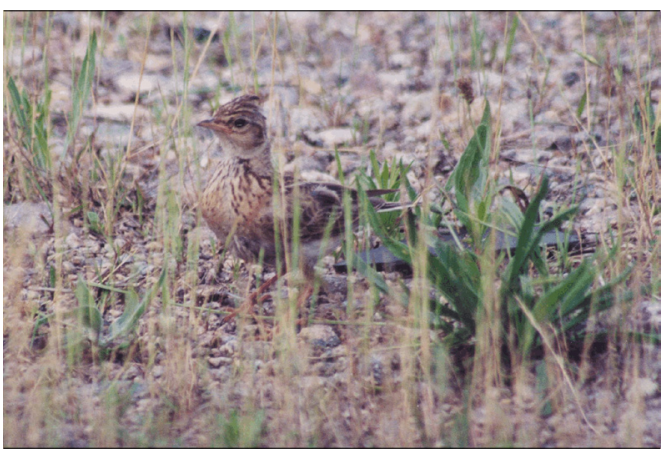

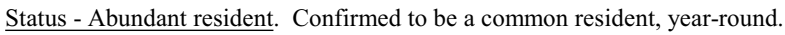

\begin{tabular}{|l|c|c|c|c|c|c|c|c|c|c|c|c|}
\hline \multicolumn{10}{|c|}{ Eurasian Skylark } \\
\hline & Jan & Feb & Mar & Apr & May & Jun & Jul & Aug & Sep & Oct & Nov & Dec \\
\hline Forests & & & & & & & & & & & & \\
\hline Wetlands & & & & & & & & & & & & \\
\hline Intertidal Zone & & & & & & & & & & & & \\
\hline Airfield & & C & U & C & c & C & C & C & & c & c & c \\
\hline Cantonment & & & & & & C & C & & & & & \\
\hline
\end{tabular}

Eurasian Skylarks typically occur in a narrow range of habitats from cultivated fields to grasslands. The short-cropped vegetation of the airfield satisfies their habitat requirements. Well-camouflaged, they are seldom visible except when flushed from the ground or when singing from an elevated post or dirt pile. Skylarks are the only birds to perform flight songs and are most frequently observed singing continuously whether hovering or circling in flight. The flight song is a diagnostic characteristic for their identification.

Eurasian Skylarks, about $17 \mathrm{~cm}$ in length, are plain brown birds with heavily streaked upperparts. Underparts are tan with streaking on the throat and breast. They have a noticeable crest that they raise when agitated. Field marks in flight are white outer tails feathers and an indistinct white rear edge on their wings. 


\section{Barn Swallow \\ Hirundo rustica}

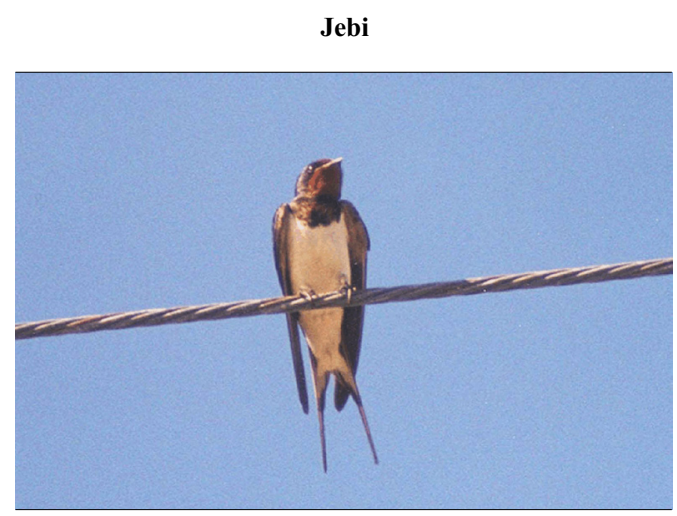

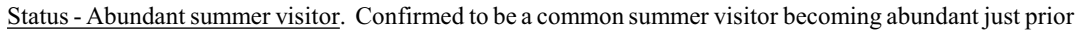
to the fall migration.

\begin{tabular}{|l|c|c|c|c|c|c|c|c|c|c|c|c|}
\hline \multicolumn{10}{|c|}{ Barn Swallow } \\
\hline & Jan & Feb & M ar & Apr & M ay & Jun & Jul & Aug & Sep & Oct & Nov & Dec \\
\hline Forests & & & & & U & C & & C & U & R & & \\
\hline Wetlands & & & & & & & & C & & & & \\
\hline Intertidal Zone & & & & & C & & & & & & & \\
\hline Airfield & & & & U & C & C & C & C & A & U & & \\
\hline Cantonment & & & & & C & C & & C & C & & & \\
\hline
\end{tabular}

The Barn Swallow is the same species as is common throughout much of North America. They prefer open country, particularly near wet rice paddies, ponds, fish farms, and tidal flats. At Kunsan, they are most often seen in small flocks feeding on insects in flight over the airfield and Little Coyote Hill. They breed throughout much of Asia, and nest under the eaves of buildings, under bridges, and on cliffs. The nests are constructed of mud and are open-topped. They migrate to southern Asia and Malaysia for the winter months.

Barn Swallows have glossy blue-black upperparts. Underparts are unmarked white except for a dark, deeplyforked tail with a band of white spots near the end. They have a deep orange forehead and throat. The throat is separated from the upper breast by a black band. 


\section{Red-rumped Swallow \\ Hirundo daurica}

\section{Gwijebi}

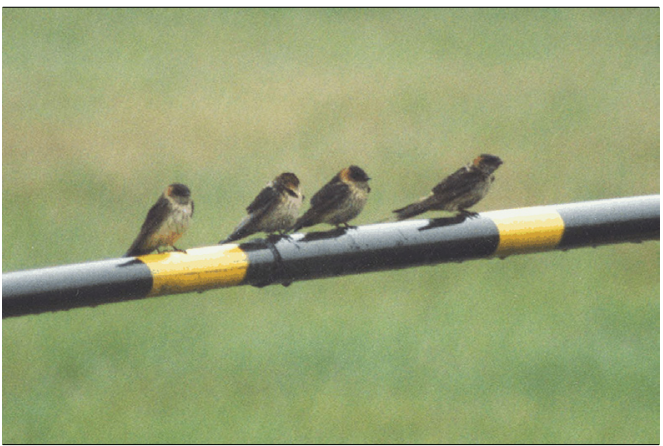

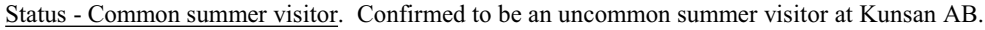

\begin{tabular}{|l|c|c|c|c|c|c|c|c|c|c|c|c|}
\hline \multicolumn{10}{|c|}{ Red-rumped Swallow } \\
\hline & Jan & Feb & M ay & Apr & May & Jun & Jul & Aug & Sep & Oct & Nov & Dec \\
\hline Forests & & & & & & & & & & & & \\
\hline Wetlands & & & & & & & & & & & & \\
\hline Intertidal Zone & & & & & & & & & & & & \\
\hline Airfield & & & & & & U & & C & & & & \\
\hline Cantonment & & & & & U & U & & U & & & & \\
\hline
\end{tabular}

Red-rumped Swallows can be locally common, but at Kunsan AB, they occur in relatively small numbers with flocks of Barn Swallows. They most commonly occur in open lowland areas like rice paddies and broad river valleys.

Red-rumped Swallows nest in small colonies under the eaves of buildings and bridge superstructures. They also build mud nests. But the nests have an extended entry tube rather than being open-topped like the Barn Swallow's nest. Their breeding range is restricted to eastern Asia. Their winter range is in southeastern Asia.

Red-rumped Swallows also have glossy blue-black upperparts. Underparts are buff-colored with fine black streaks and a dark, deeply forked tail. The face is darkly streaked, and there is an orange eyebrow cap on the nape of the neck. In flight, the brick red-colored rump is visible, giving the bird its common name. 


\section{White Wagtail}

Motacilla alba

Allakhalmisae

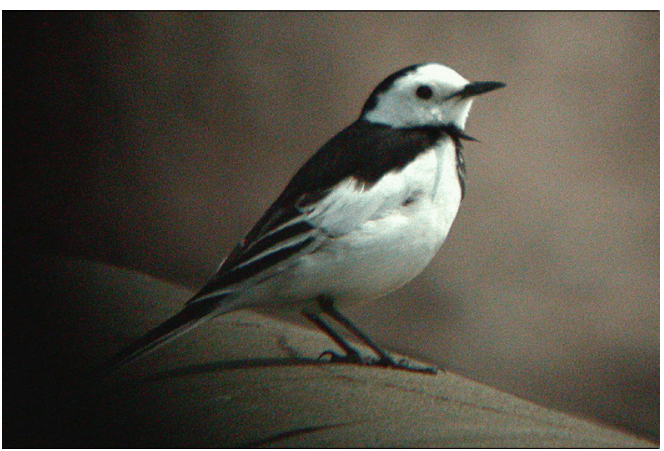

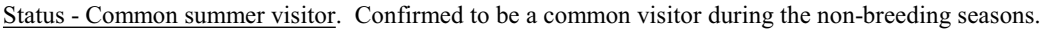

\begin{tabular}{|l|l|l|l|l|l|l|l|l|l|l|l|l|}
\hline \multicolumn{10}{|c|}{ White Wagtail } \\
\hline & Jan & Feb & Mar & Apr & M ay & Jun & Jul & Aug & Sep & Oct & Nov & Dec \\
\hline Forests & & & & & & & & U & & & & \\
\hline Wetlands & & & & & & & & & & & & \\
\hline Intertidal Zone & & & & & & & & & & & & \\
\hline Airfield & & & U & U & U & C & & C & C & C & & U \\
\hline Cantonment & & R & C & & C & C & & C & C & U & & \\
\hline
\end{tabular}

White Wagtails prefer habitats containing water, especially drainage ditches, stream banks, and paddy field edges. They breed and nest throughout Korea, China, and much of Siberia. They are year-round residents along the extreme southern edge of Korea, but the majority overwinter in China and southeastern Asia.

White Wagtails are approximately $18 \mathrm{~cm}$ in length. Their crown, nape, and back are black. Their undersides are white. They have a prominent black bib on their breast. The two most obvious field marks are an unmarked white face and a blackand-white primary wing feather pattern over the lower back. They also bob their tails up-and-down when walking or standing.

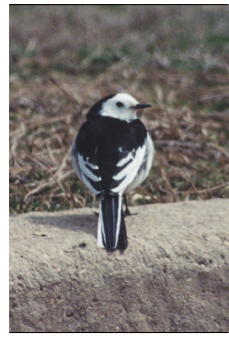




\section{Black-backed Wagtail \\ Motacilla lugens}

\section{Baekhalmisae}

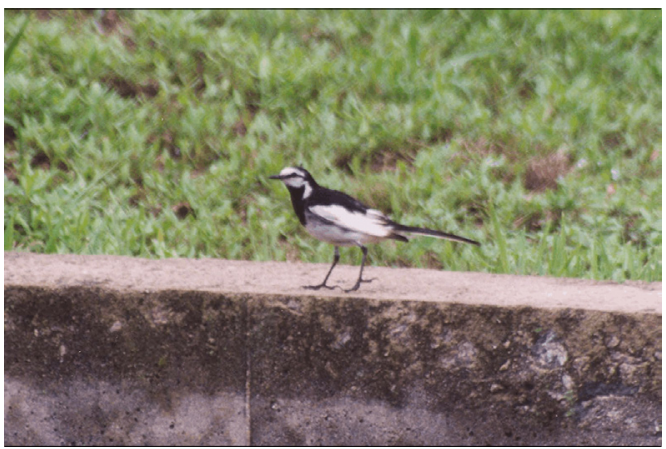

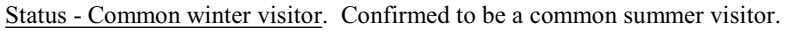

\begin{tabular}{|l|c|c|c|c|c|c|c|c|c|c|c|c|}
\hline \multicolumn{10}{|c|}{ Black-backed Wagtail } \\
\hline & Jan & Feb & M ar & Apr & May & Jun & Jul & Aug & Sep & Oct & Nov & Dec \\
\hline Forests & & & & & & & & & & & & \\
\hline Wetlands & & & & & & & & & & & & \\
\hline Intertidal Zone & & & & & & & & C & & & & \\
\hline Airfield & & & & & & U & C & C & & & & \\
\hline Cantonment & & & & & & U & & & & & & \\
\hline
\end{tabular}

Black-backed Wagtails occur in a wide variety of habitats but mainly prefer open cultivated areas along rivers and coasts. They tend to forage for insects in drier areas than the White Wagtail. They appear to breed and nest in Korea and Japan. They overwinter along the Japanese archipelago and along the south China coast.

Until recently, Black-backed Wagtails were considered a subspecies of White Wagtails. However, taxonomists now consider them a separate species. Black-backed Wagtails are somewhat larger than White Wagtails, often $21 \mathrm{~cm}$ in length owing to their obviously longer tail. Their black breast patch is much larger than the White Wagtail's, extending upward to include the throat and continuing over the shoulder where it joins with the back. The individual above displays grey flanks immediately below the wings. They can best be distinguished by their prominent black eye stripe and obvious white wing primaries. They bob their tails up-and-down when walking or standing. 


\section{Buff-bellied Pipit}

Anthus rubescens

\section{Batjongdari}

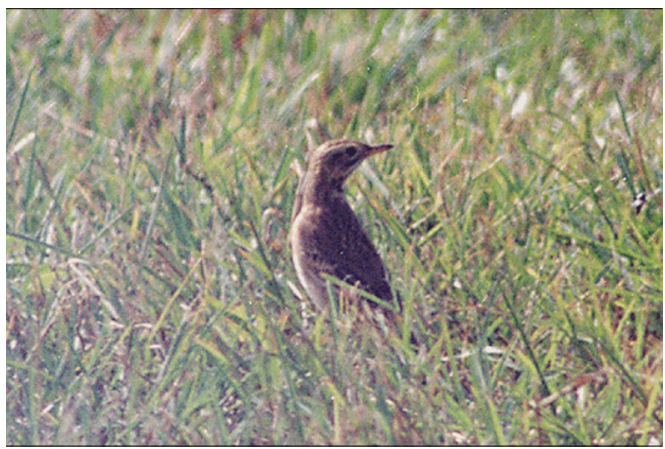

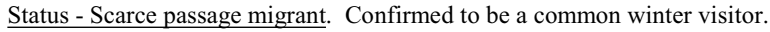

\begin{tabular}{|l|l|l|l|l|l|l|l|l|l|l|l|l|}
\hline \multicolumn{10}{|c|}{ Buff-bellied Pipit } \\
\hline & Jan & Feb & M ar & Apr & May & Jun & Jul & Aug & Sep & Oct & Nov & Dec \\
\hline Forests & & & & & & & & & & & & \\
\hline Wetlands & & & & & & & & & & & & \\
\hline Intertidal Zone & & & & & & & & & & & & \\
\hline Airfield & & & & & & & & & C & C & C & C \\
\hline Cantonment & & & & & & & & & & & C & \\
\hline
\end{tabular}

The Buff-bellied Pipit is the same species known as the "American Pipit" in North and Central America. They are obviously common and widespread. They typically nest on the tundra in the north and alpine tundra farther south. Winter flocks congregate in damp, grassy fields and beaches of southern Korea, Japan, and along the China coast. At Kunsan, they are most commonly encountered during the winter months on the airfield.

At least seven species of pipits occur in Korea. As a group, pipits are relatively small (15 to $18 \mathrm{~cm}$ in length), plain, brownish birds with varying degrees of breast striping between species. Like wagtails, pipits bob their tails up-and-down when walking or standing. Non-breeding plumage of the Buff-bellied Pipit is brown on the head, back, and tail. The underparts are generally a creamy-buff with heavy streaking and spotting on the lower throat, breast, and sides. A good field mark is the bold, black whisker mark that joins the streaking and spotting on the upper breast. 


\section{Olive-backed Pipit}

Anthus hodgsoni

\section{Hingdungsae}

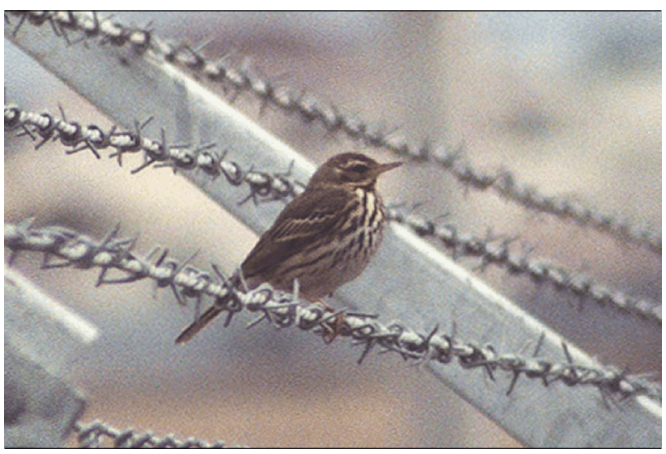

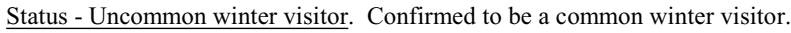

\begin{tabular}{|l|c|c|c|c|c|c|c|c|c|c|c|c|}
\hline \multicolumn{10}{|c|}{ Olive-backed Pipit } \\
\hline & Jan & Feb & M ar & Apr & M ay & Jun & Jul & Aug & Sep & Oct & Nov & Dec \\
\hline Forests & & C & & & & & & & U & & U & C \\
\hline Wetlands & & & & & & & & & & & & \\
\hline Intertidal Zone & & & & & & & & & & & & \\
\hline Airfield & & U & & & & & & & & & & \\
\hline Cantonment & & C & U & U & & & & & & & & \\
\hline
\end{tabular}

Olive-backed Pipits prefer edges of pine woods and thickets with adjacent grasslands. They can commonly be observed on the lawns throughout the cantonment area and along the wooded edges of POL-north. Southern Korea appears to be the northern edge of their winter range, as they are more common throughout southern China during the winter. They nest and breed throughout much of Siberia.

The Olive-backed Pipit is probably the easiest pipit to identify in winter plumage. The back is an oliveyellow with indistinct black streaks. The underside is a creamy-white with bold black streaks and spots on the breast and sides. The best field marks are a distinct whitish eyebrow and a smaller, less-distinct white "ear spot." Behavior characteristics can also be reliable field marks. For the Olive-backed Pipit, a preference for dry, wooded or shrub habitats and a tendency to perch (and sing) in trees or fences differentiate Olivebacked Pipits from their grassland-dwelling relatives. 


\section{Brown-eared Bulbul}

Hypsipetes amaurotis

\section{Jikbakguri}

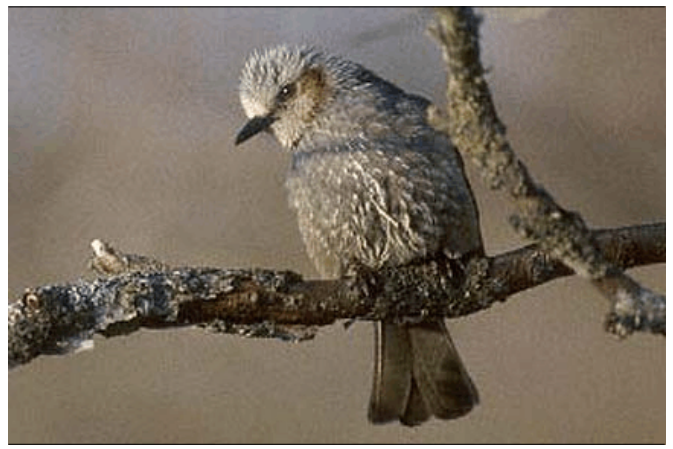

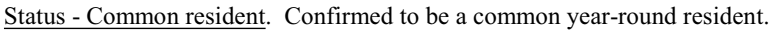

\begin{tabular}{|l|c|c|c|c|c|c|c|c|c|c|c|c|}
\hline \multicolumn{10}{|c|}{ Brown-eared Bulbul } \\
\hline & Jan & Feb & M ar & Apr & M ay & Jun & Jul & Aug & Sep & Oct & Nov & Dec \\
\hline Forests & C & C & C & C & C & C & & C & U & U & C & c \\
\hline Wetlands & & & & & & & & & & & & \\
\hline Intertidal Zone & & & & & & & & & & & & \\
\hline Airfield & & & U & & U & U & & & & & U & \\
\hline Cantonment & C & C & U & & & C & & & & & & U \\
\hline
\end{tabular}

Brown-eared Bulbuls are common, noisy, and conspicuous residents of low mountain forests, city parks, and gardens. Their range is limited to the Korean Peninsula and southern Japan. Not numerous on base, small flocks of up to 6 individuals occupy the POL-north area. It is likely that they breed and nest there, also. They feed on insects, garden vegetables, and ripening fruits. They can become a pest for local gardeners. They are aggressive towards other feeding birds. They are vocal and often squawk loudly in flight from location to location.

Brown-eared Bulbuls are medium-sized birds with long tails, reaching approximately $28 \mathrm{~cm}$ in total length. They are grey with silvery streaking on their heads and light grey streaking on their underparts. The primary and secondary wing feathers and tail often have a warm chocolate brown tint to them. The primary field mark is their chestnut-brown ear crescent. (Brown-eared Bulbul photographed by Robert Dalzell.) 


\section{Bull-headed Shrike}

Lanius bucephalus

\section{Ttaekkachi}

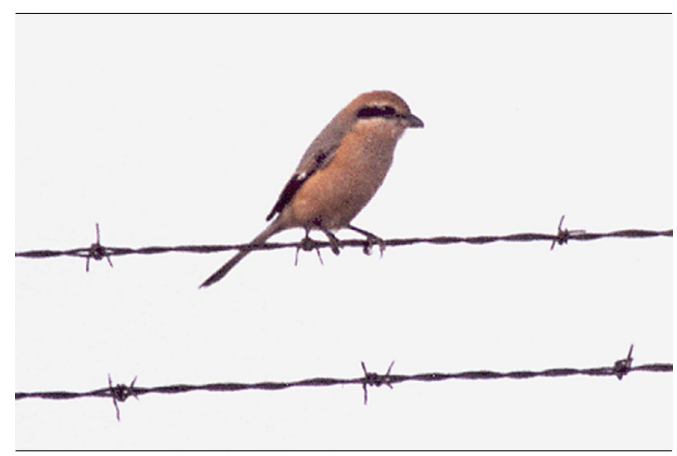

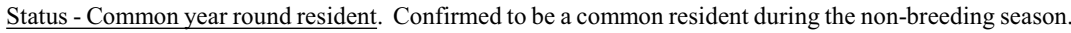

\begin{tabular}{|l|c|c|c|c|c|c|c|c|c|c|c|c|}
\hline \multicolumn{10}{|c|}{ Bull-headed Shrike } \\
\hline & Jan & Feb & Mar & Apr & May & Jun & Jul & Aug & Sep & Oct & Nov & Dec \\
\hline Forests & & & & & & & & & & U & & \\
\hline Wetlands & & & & & & & & & & & & \\
\hline Intertidal Zone & & & & & & & & & & & & \\
\hline Airfield & C & U & & & & R & & & U & C & U & U \\
\hline Cantonment & & & & & & & & & & & U & \\
\hline
\end{tabular}

Bull-headed Shrikes inhabit open areas with perches. During the non-breeding season, they frequently perch on the southern perimeter fence overlooking the grassy area between the Perimeter Road and the perimeter fence. Their prey is extremely varied and includes insects, worms, small birds and mammals, frogs, fish, and even crustaceans. Shrikes have the unusual habit of impaling their captured prey on sharp twigs or even razor-wire spikes. During the breeding season, they are rare on base. Presumably, they move to higher elevations where they nest in open scrub forests.

Bull-headed Shrikes are medium-sized birds reaching $20 \mathrm{~cm}$ in length. The males are brightly colored with a brown crown and nape, a bold black eye stripe, grey back, and black wing primaries. The underparts vary depending on the season from pale tan to whitish. A good field mark for the males is a small but conspicuous white spot on the wing. Females lack the white wing patch and black eye stripe, but have fine, wavy bars on their underparts. 


\section{Brown Shrike}

Lanius cristatus

Norang-ttaekkachi

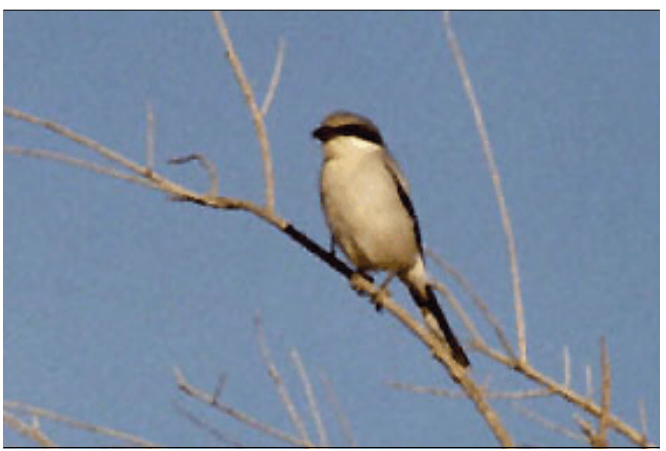

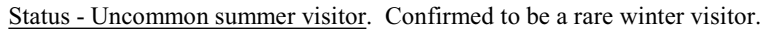

\begin{tabular}{|l|c|c|c|c|c|c|c|c|c|c|c|c|}
\hline \multicolumn{10}{|c|}{ Brown Shrike } \\
\hline & Jan & Feb & M ar & Apr & M ay & Jun & Jul & Aug & Sep & Oct & Nov & Dec \\
\hline Forests & & & & & & & & & & & & \\
\hline Wetlands & & & & & & & & & & & & \\
\hline Intertidal Zone & & & & & & & & & & & & \\
\hline Airfield & & R & & & & & & & & & & \\
\hline Cantonment & R & & & & & & & R & & & & \\
\hline
\end{tabular}

Brown Shrikes are supposed to be present in the summer. But at Kunsan, they are more commonly observed in the depths of winter. It is possible that a few individuals overwinter in the Kunsan area. More typically, they overwinter throughout the southern half of China and southward.

Brown Shrikes are also about $20 \mathrm{~cm}$ in length. They are reddish-brown above with whitish underparts. There are two subspecies of Brown Shrikes. The individual pictured above is the subspecies $L$. c . lucionensis, reputed to be a summer visitor and lacks a conspicuous, broad white eyebrow above the black eye mask. 


\section{Daurian Redstart}

Phoenicurus auroreus

\section{Ttaksae}

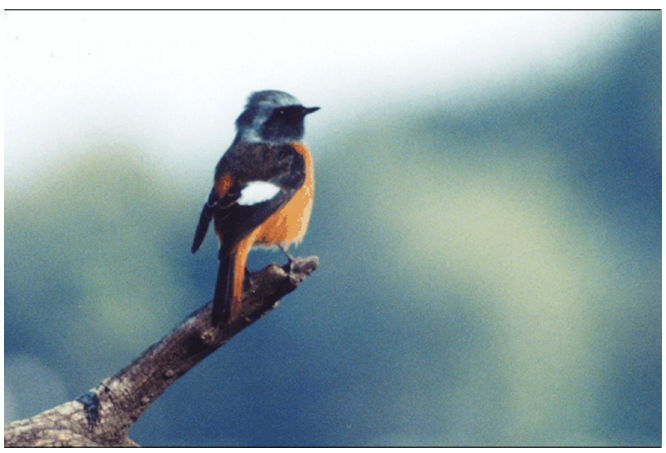

Status - Common resident. Confirmed to be a common winter visitor.

\begin{tabular}{|l|c|c|c|c|c|c|c|c|c|c|c|c|}
\hline \multicolumn{10}{|c|}{ Daurian Redstart } \\
\hline & Jan & Feb & Mar & Apr & M ay & Jun & Jul & Aug & Sep & oct & Nov & Dec \\
\hline Forests & & & & & U & & & & & & c & c \\
\hline Wettands & & & & & & & & & & & & \\
\hline Intertidal Zone & & & & & & & & & & & & \\
\hline Airfield & C & U & & & & & & & & & c & c \\
\hline Cantonment & C & U & U & C & C & & & & & & c & c \\
\hline
\end{tabular}

Male Daurian Redstarts are conspicuous because they often perch on the highest bare branch or wire around while singing their unique song. They are year-round residents of Korea, but seem to be absent from the Kunsan area during the breeding season. During that time, they either move to higher elevations or migrate to northeastern China and Siberia to breed.

Male Daurian Redstarts are striking birds with a silvery-white crown and nape, and black face, back, wings, and tail center. The breast, belly, vent, and outer tail feathers are bright orange. Females are brown overall except for a light orange rump, vent, and outer tail feathers. The best field mark for both sexes is the bold white wing patch.

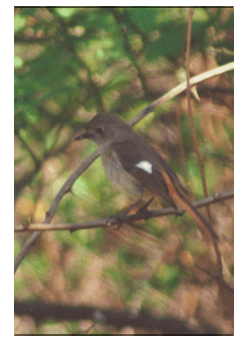




\section{Common Stonechat}

Saxicola torquata

\section{Geomeunttaksae}

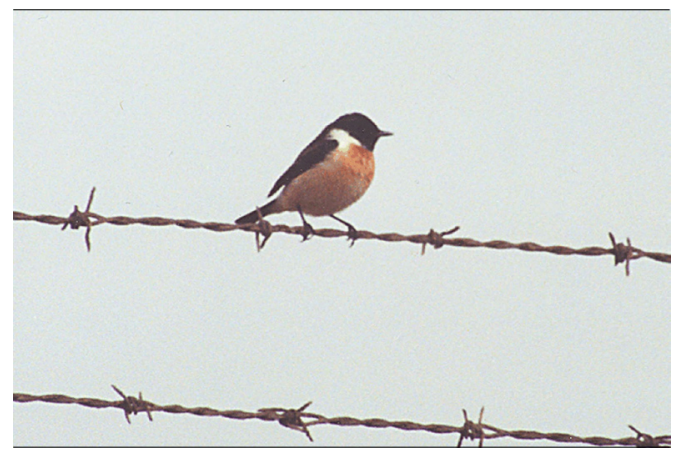

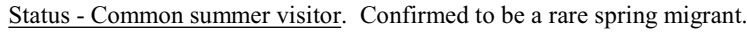

\begin{tabular}{|l|l|l|l|l|l|l|l|l|l|l|l|l|}
\hline \multicolumn{10}{|c|}{ Common Stonechat } \\
\hline & Jan & Feb & M ar & Apr & M ay & Jun & Jul & Aug & Sep & Oct & Nov & Dec \\
\hline Forests & & & & & & & & & & & & \\
\hline Wetlands & & & & & & & & & & & & \\
\hline Intertidal Zone & & & & & & & & & & & & \\
\hline Airfield & & & & & & & & & & & & \\
\hline Cantonment & & & R & & & & & & & & & \\
\hline
\end{tabular}

Common Stonechats occupy paddy fields, riverbanks, and reed beds during their migration. Only a single Common Stonechat was observed during the avian surveys at Kunsan AB. The single individual was photographed at the entrance road to Little Coyote Hill. Although reported as a year-round resident, they apparently migrate farther north or seek higher elevations.

Male Common Stonechats have black heads, backs, wings, and tails. They have a white collar, wing patch, and rump. The undersides are generally pale orange. Females have brown heads and upper parts streaked with black. They also display a white eyebrow, throat, and wing patch. Underparts are a pale yellowishbrown. 


\section{Blue Rock Thrush}

Monticola solitarius

\section{Badajikbakguri}

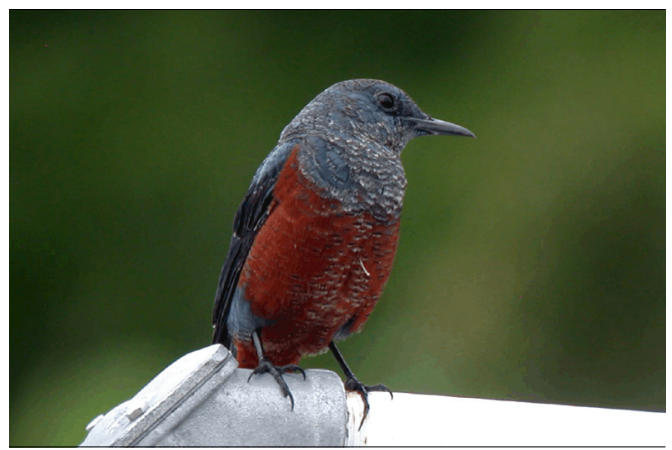

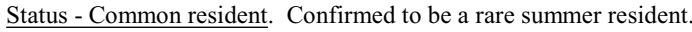

\begin{tabular}{|l|l|l|l|l|l|l|l|l|l|l|l|l|}
\hline \multicolumn{10}{|c|}{ Blue Rock Thrush } \\
\hline & Jan & Feb & M ar & Apr & M ay & Jun & Jul & Aug & Sep & Oct & Nov & Dec \\
\hline Forests & & & & & & & & & & & & \\
\hline Wetlands & & & & & & & & & & & & \\
\hline Intertidal Zone & & & & & & & & & & & & \\
\hline Airfield & & & & & & R & & & & & & \\
\hline Cantonment & & & & & & R & & & & & & \\
\hline
\end{tabular}

In Korea, the Blue Rock Thrush inhabits the southern islands, rocky seashores, and harbor areas. They also seem to be well adapted to human presence and man-made structures. At Kunsan, Blue Rock Thrushes characteristically sit atop the corners of buildings on both Little and Big Coyote Hills. From those vantage points, they either sing to declare their territory or fly to the ground to forage for insects. During midday, they can often be found seeking cover in the shade under parked vehicles.

The male Blue Rock Thrush has an iridescent Slaty-blue head, breast, back, and rump. The wings and tail are blackish. The belly and rump a dull orange. The female is grey-brown with hints of blue-grey streaks on the head. Her underparts are spotted dark yellow. (Blue Rock Thrush photographed at Kadena AB.) 


\section{Dusky Thrush}

Turdus naumann

\section{Gaettongjippagwi}

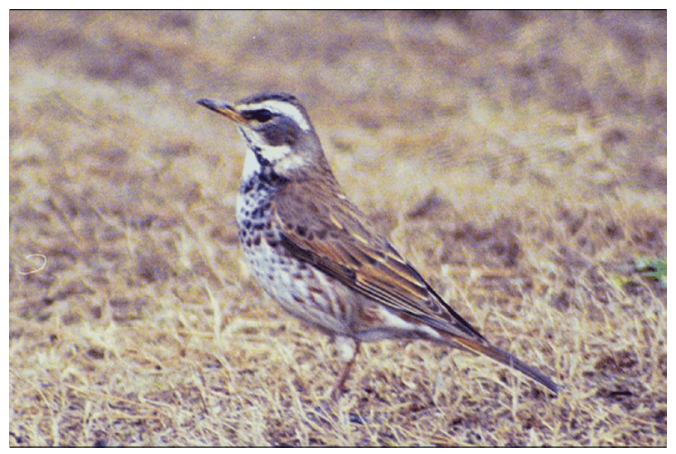

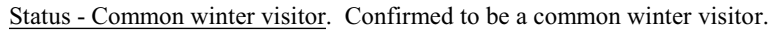

\begin{tabular}{|l|c|c|c|c|c|c|c|c|c|c|c|c|}
\hline \multicolumn{10}{|c|}{ Dusky Thrush } \\
\hline & Jan & Feb & M ar & Apr & M ay & Jun & Jul & Aug & Sep & Oct & Nov & Dec \\
\hline Forests & & C & C & & & & & & & & & \\
\hline Wetlands & & & & & & & & & & & & \\
\hline Intertidal Zone & & & & & & & & & & & & \\
\hline Airfield & & C & & & & & & & & & & \\
\hline Cantonment & C & C & C & U & & & & & & & & \\
\hline
\end{tabular}

The Dusky Thrush is the most common thrush in the winter. They are birds of open cultivated fields, open woods, river banks, and city parks. On Kunsan, they often appear in large flocks on the golf course and in the open grassy lawns of the officers' housing areas. Typically they nest and breed in Siberia.

The plumage of the Dusky Thrush is highly variable. Two subspecies have been described, and there is a continuous plumage variation from one form to the other. But in all cases, they have brown upper parts, rufous-red on the wings, and creamy white eyebrows and malar areas. The underparts are generally white with varying degrees of blotching, either black or orange.

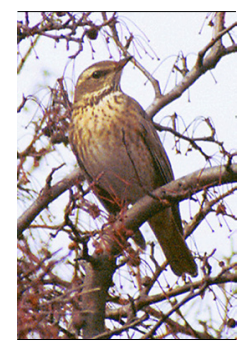




\section{Eye-browed Thrush}

Turdus obscurus

\section{Huinnunsseopbulgeunbaejippagwi}

\section{Not \\ Photographed}

Status - Scarce passage migrant. Confirmed to be an uncommon passage migrant observed in the POL-north area in May 2005.

\begin{tabular}{|l|c|c|c|c|c|c|c|c|c|c|c|c|}
\hline \multicolumn{10}{|c|}{ Eye-browed Thrush } \\
\hline & Jan & Feb & M ar & Apr & M ay & Jun & Jul & Aug & Sep & Oct & Nov & Dec \\
\hline Forests & & & & & & & & & & & & \\
\hline Wetlands & & & & & & & & & & & & \\
\hline Intertidal Zone & & & & & & & & & & & & \\
\hline Airfield & & & & & & & & & & & & \\
\hline Cantonment & & & & & U & & & & & & & \\
\hline
\end{tabular}

The Eye-browed Thrush is more common in Korea during the fall migration than in the spring. They breed in the forested regions of Siberia and spend the non-breeding season in southern China, although a few winter in southern Japan. During migration, they are most often encountered along forest edges and in urban parks.

The Eye-browed Thrush, also known as the Grey-headed Thrush, reaches about $21.5 \mathrm{~cm}$ in length. The male typically has a greyish head with a distinct white eyebrow above a black eyeline. The back, wings, rump, and tail are brown. The breast and flanks are russet or orangish, contrasting with a white belly and vent. The female lacks the grey head and has a white throat with prominent black streaks. 


\section{Fan-tailed Warbler \\ Cisticola juncidis}

\section{Gaegaebisachon}

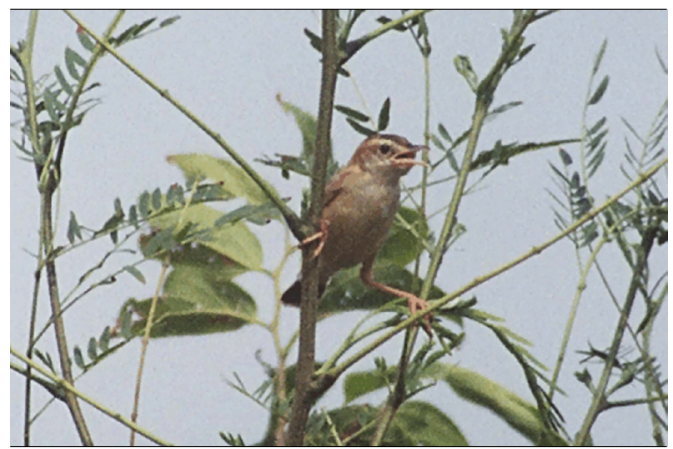

Status - Scarce summer resident. Confirmed to be an uncommon to common summer resident.

\begin{tabular}{|l|c|c|c|c|c|c|c|c|c|c|c|c|}
\hline \multicolumn{10}{|c|}{ Fan-tailed Warbler } \\
\hline & Jan & Feb & Mar & Apr & May & Jun & Jul & Aug & Sep & Oct & Nov & Dec \\
\hline Forests & & & & & & & & & & & & \\
\hline Wetlands & & & & & & c & & & & & & \\
\hline Intertidal Zone & & & & & & & & & & & & \\
\hline Airfield & & & & & & U & & & & & & \\
\hline Cantonment & & & & & & & & & & & & \\
\hline
\end{tabular}

On Kunsan AB, the Fan-tailed Warbler inhabits moist weedy areas adjacent to the land farm, on the airfield, and in the CE bulk storage area. They sing in flight with one song during ascent, hovering with their tail fanned open, and then singing another song during descent. Kunsan is near the northern edge of their breeding range in continental Asia. They migrate to southern Japan, China, and southeastern Asia to overwinter.

The Fan-tailed Warbler is a small bird barely exceeding $12 \mathrm{~cm}$ in length. Overall, they are brownish birds with black-streaked wings and back. Their flanks are brownish grading into a grey belly and vent. The tail is barred with black-and-white on the underside. The upper side is cinnamon-brown with a subterminal black band with a white tip. (Fantailed Warbler photographed on Kadena AB.)

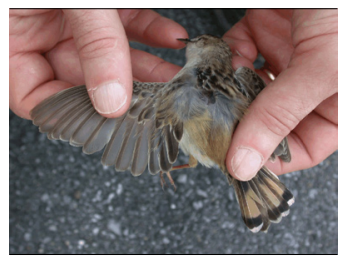




\section{Short-tailed Bush Warbler \\ Urosphena squameiceps}

\section{Supsae}

\section{Not \\ Photographed}

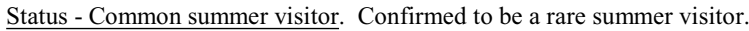

\begin{tabular}{|l|c|c|c|c|c|c|c|c|c|c|c|c|}
\hline \multicolumn{10}{|c|}{ Short-tailed Bush Warbler } \\
\hline & Jan & Feb & M ar & Apr & M ay & Jun & Jul & Aug & Sep & Oct & Nov & Dec \\
\hline Forests & & & & & & & & & & & & \\
\hline Wetlands & & & & & & & & & & & & \\
\hline Intertidal Zone & & & & & & & & & & & & \\
\hline Airfield & & & & & R & & & & & & & \\
\hline Cantonment & & & & & & & & & & & & \\
\hline
\end{tabular}

The Short-tailed Bush Warbler inhabits densely vegetated lowland hills. They forage for insects and other invertebrates in the foliage close to the ground. Secretive birds, their presence is often overlooked. On Kunsan, they have only been observed during the spring migration in the POL-north area. But, they are known to breed and nest throughout Korea, Japan, and northeastern China. They overwinter from southern China southward.

Very small, the Short-tailed Bush Warbler attains only $10.5 \mathrm{~cm}$ in length. Their heads, backs, wings, tail, and flanks are dark brown. They have no wing bars. Beneath, they are lighter brown to almost whitish. They have a distinct buff-colored eyebrow and a distinct black eyeline. True to their common name, they have a very short tail. 


\title{
Goldcrest
}

Regulus regulus

Sangmosolsae

\author{
Not \\ Photographed
}

Status - Common winter visitor. Confirmed to be a common passage migrant.

\begin{tabular}{|l|c|c|c|c|c|c|c|c|c|c|c|c|}
\hline \multicolumn{10}{|c|}{ Goldcrest } \\
\hline & Jan & Feb & M ar & Apr & M ay & Jun & Jul & Aug & Sep & Oct & Nov & Dec \\
\hline Forests & & & U & & C & & & & & & & \\
\hline Wetlands & & & & & & & & & & & & \\
\hline $\begin{array}{l}\text { Intertidal } \\
\text { Zone }\end{array}$ & & & & & & & & & & & & \\
\hline Airfield & & & & & & & & & R & & R & \\
\hline Cantonment & & & & & & & & & & & & \\
\hline
\end{tabular}

Goldcrests typically occupy the coniferous forests found at higher elevations during the summer. During the winter, they descend to lower elevations where they still prefer coniferous forests and plantations. At Kunsan, they were observed in the pines along the seawall or at the crest of Wolf Pack Park. They often hover while they glean small insects from the conifer branches.

The Goldcrest is the smallest bird to occur on Kunsan, reaching only about $9 \mathrm{~cm}$ in length. Overall, they are a deep olive-green above and somewhat lighter beneath. They have a faint grey eye ring. Their wings are black with white feather edges and an apparent white wing bar. They get their common name from their bright yellow crown stripe bordered in black. On occasion, one can see a reddish orange center in the yellow crown stripe. They are very similar in size and appearance to the Golden-crowned Kinglet $(R$. satrapa $)$ found throughout most of North America. 


\section{Oriental Great Reed Warbler}

Acrocephalus orientalis

\section{Gaegaebi}

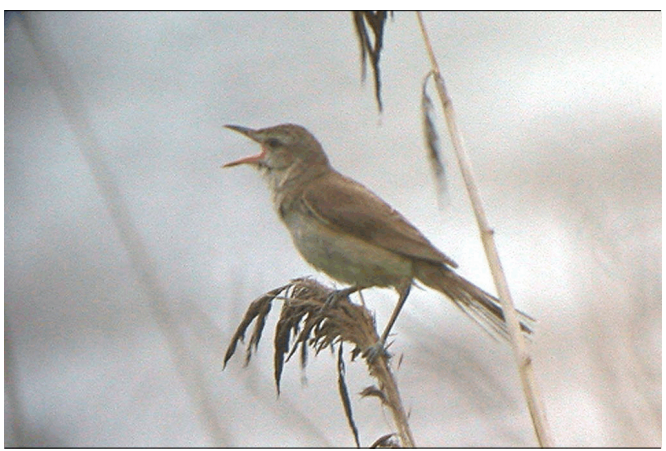

Status - Common summer visitor. Confirmed to be a common summer visitor.

\begin{tabular}{|l|c|c|c|c|c|c|c|c|c|c|c|c|}
\hline \multicolumn{10}{|c|}{ Oriental Great Reed Warbler } \\
\hline & Jan & Feb & Mar & Apr & May & Jun & Jul & Aug & Sep & Oct & Nov & Dec \\
\hline Forests & & & & & & & & & & & & \\
\hline Wetlands & & & & & C & C & & & & & & \\
\hline Intertidal Zone & & & & & & & & & & & & \\
\hline Airfield & & & & & C & C & & C & & & & \\
\hline Cantonment & & & & & & & & & & & & \\
\hline
\end{tabular}

The Oriental Great Reed Warbler inhabits coastal and inland reedbeds. On Kunsan, that habitat exists beyond the perimeter fence adjacent to the cargo hot pad and also along the drainage ditch that traverses the CE bulk storage yard. In those locations, the noisy Oriental Great Reed Warbler commonly nests. During the non-breeding season, they migrate to southeastern Asia and Malaysia.

The Oriental Great Reed Warbler is a relatively large warbler reaching $18.5 \mathrm{~cm}$ in length. Above, they are a dull brown. They have a distinct grey eyebrow and a thin black eyeline. The underside is dull grey. When singing, their bright orange gape is clearly visible.

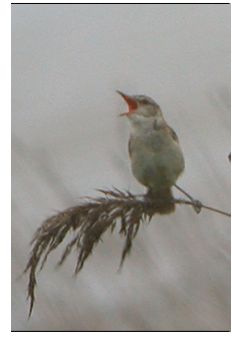




\section{Yellow-browed Warbler}

Phylloscopus inornatus

Norangnunsseopsolsae

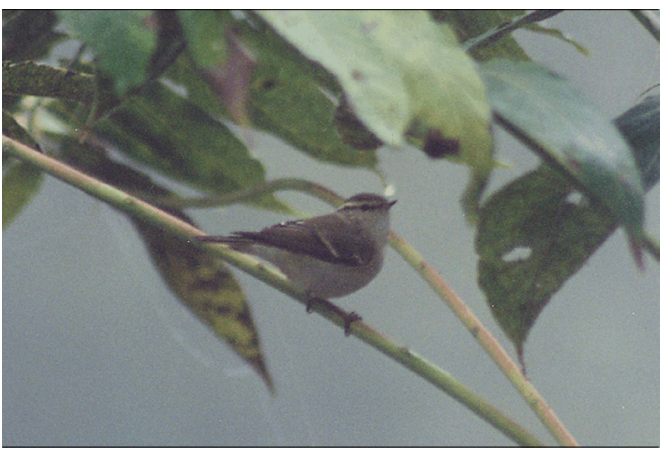

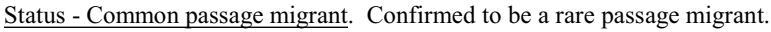

\begin{tabular}{|l|l|l|l|l|l|l|l|l|l|l|l|l|}
\hline \multicolumn{7}{|c|}{ Yellow-browed Warbler } \\
\hline & Jan & Feb & Mar & Apr & M ay & Jun & Jul & Aug & Sep & oct & Nov & Dec \\
\hline Forests & & & & & & & & & & R & & \\
\hline Wetlands & & & & & & & & & & & & \\
\hline Intertidal Zone & & & & & & & & & & & & \\
\hline Airfield & & & & & & & & & & R & & \\
\hline Cantonment & & & & & & & & & & & & \\
\hline
\end{tabular}

The Yellow-browed Warbler breeds in the forested areas of northern China and Siberia. During the nonbreeding season, they inhabit the forests of southern China. On base, they were observed in mixed flocks with Great Tits (P. major) and Goldcrests (Regulus regulus) in the POL-north area and in the pines along the seawall.

The tiny Yellow-browed Warbler reaches only about $10.5 \mathrm{~cm}$ in length. They are generally brownish with olive-green highlights above and greyish below. They have a creamy-white eyebrow that contrasts with a darker cap above and an indistinct dark eyeline. They generally have one to one-an-a-half whitish wing bars. 


\section{Eastern Crowned Willow Warbler \\ Phylloscopus coronatus}

\section{Sansolsae}

\section{Not \\ Photographed}

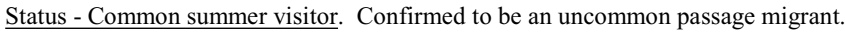

\begin{tabular}{|l|c|c|c|c|c|c|c|c|c|c|c|c|}
\hline \multicolumn{10}{|c|}{ Eastern Crowned Willow Warbler } \\
\hline & Jan & Feb & Mar & Apr & M ay & Jun & Jul & Aug & Sep & Oct & Nov & Dec \\
\hline Forests & & & & & U & & & & & & & \\
\hline Wettands & & & & & & & & & & & & \\
\hline Intertidal Zone & & & & & & & & & & & & \\
\hline Airfield & & & & & & & & & & & & \\
\hline Cantonment & & & & & & & & & & & & \\
\hline
\end{tabular}

Eastern Crowned Willow Warblers are reported to nest and breed throughout Korea, Japan, and northeastern China. They prefer deciduous and mixed forests but can be common in parks and gardens, as well. However, on Kunsan AB, they appear to be only uncommon passage migrants.

Eastern Crowned Willow Warblers are small warblers reaching about $12.5 \mathrm{~cm}$ in length. They are olivegreen above and greyish beneath with a yellow vent area. They have a single, indistinct whitish wing bar and a distinct white eyebrow that is outlined with black above and below. Their lower mandible is orange like many warblers, but it is more obvious than most. 


\section{Tricolor Flycatcher \\ Ficedula zanthopygia}

\section{Huinnunsseophwanggeumsae}

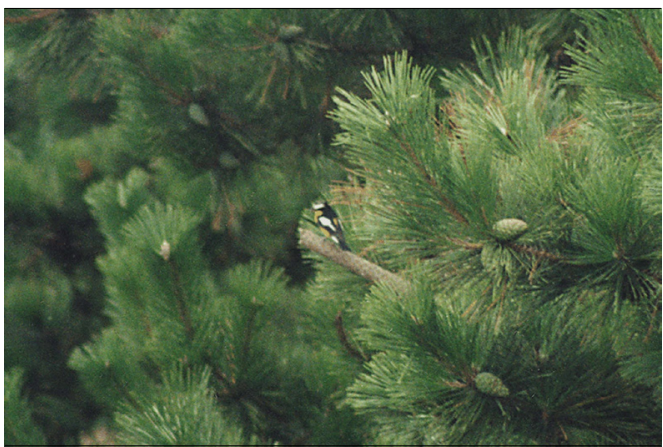

Status - Uncommon summer visitor. Confirmed to be an uncommon to rare passage migrant.

\begin{tabular}{|l|c|c|c|c|c|c|c|c|c|c|c|c|}
\hline \multicolumn{10}{|c|}{ Tricolor Flycatcher } \\
\hline & Jan & Feb & M ar & Apr & M ay & Jun & Jul & Aug & Sep & Oct & Nov & Dec \\
\hline Forests & & & & & & & & & & & & \\
\hline Wetlands & & & & & & & & & & & & \\
\hline Intertidal Zone & & & & & & & & & & & & \\
\hline Airfield & & & & U & & & & R & & & & \\
\hline Cantonment & & & & & & & & & & & & \\
\hline
\end{tabular}

Tricolor Flycatchers prefer open deciduous forests, parks, and gardens. They are reported to nest and breed throughout Korean and northeastern China. They overwinter in southeastern Asia.

Tricolor Flycatchers are small (13 cm in length) and brilliantly colored. The male's head, upper back, wings, and tail are black. Their throat, breast, and belly are bright yellow. They have large white wing patches and yellow lower backs and rumps. The diagnostic field mark is the bold white eyebrow. The female is olivebrown above and greyish beneath. The female shares the yellow rump and white wing patches of the male. Both sexes are quite similar in appearance to the Narcissus Flycatcher $(F$. narcissina). 


\section{Narcissus Flycatcher}

Ficedula narcissina

\section{Hwanggeumsae}

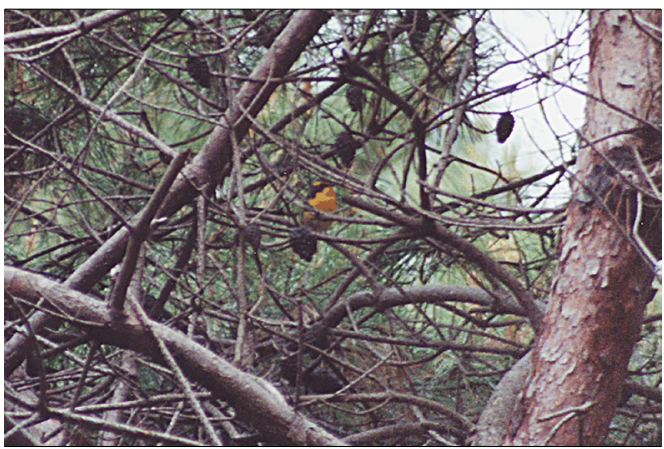

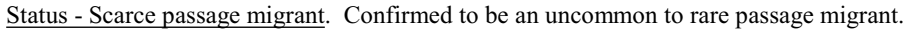

\begin{tabular}{|l|c|c|c|c|c|c|c|c|c|c|c|c|}
\hline \multicolumn{10}{|c|}{ Narcissus Flycatcher } \\
\hline & Jan & Feb & Mar & Apr & May & Jun & Jul & Aug & Sep & Oct & Nov & Dec \\
\hline Forests & & & & U & & & & & & & & \\
\hline Wetlands & & & & & & & & & & & & \\
\hline Intertidal Zone & & & & & & & & & & & & \\
\hline Airfield & & & & & & & & & & & R & \\
\hline Cantonment & & & & U & & & & & & & & \\
\hline
\end{tabular}

The sightings and record of the Narcissus Flycatchers at Kunsan are apparently unusual. They were observed in the pines adjacent to the billeting office and in the pines along the seawall. The individual above was photographed in Wolf Pack Park. They nest and breed in the mixed deciduous-conifer hill forests of Japan. They prefer habitats with dense undergrowth. And they apparently migrate along the Japanese archipelago to overwinter in the Philippines.

Narcissus Flycatchers are also small (13.5 cm in length) and brilliantly colored. The male's head, back, wings, and tail are black. Their throat and upper breast are bright orange, which grades to a bright yellow belly. They have large white wing patches and bright yellow rumps. The diagnostic field mark is the bold yellow-orange eyebrow. The female is olive-brown above and greyish-brown beneath, with brown mottling on the breast. The female shares the white patches of the male but lacks the yellow rump. Both sexes are similar in appearance to the Tricolor Flycatcher (F. zanthopygia). 


\section{Grey-spotted Flycatcher \\ Muscicapa griseisticta}

\section{Jebi-ttaksae}

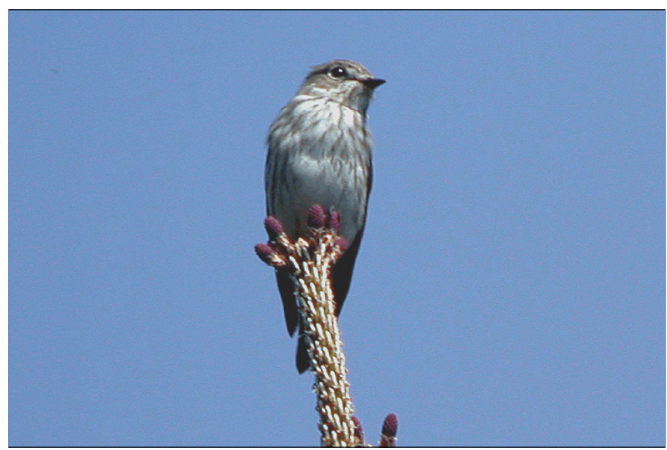

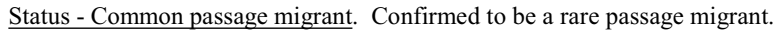

\begin{tabular}{|l|c|c|c|c|c|c|c|c|c|c|c|c|}
\hline \multicolumn{10}{|c|}{ Grey-spotted Flycatcher } \\
\hline & Jan & Feb & M ar & Apr & M ay & Jun & Jul & Aug & Sep & Oct & Nov & Dec \\
\hline Forests & & & & & R & & & & & & & \\
\hline Wetlands & & & & & & & & & & & & \\
\hline Intertidal Zone & & & & & & & & & & & & \\
\hline Airfield & & & & & & & & & & & & \\
\hline Cantonment & & & & & & & & & & & & \\
\hline
\end{tabular}

The Grey-spotted Flycatcher nests and breeds in northeastern China and Russia, including the Kamchatka Peninsula. They overwinter in the Philippines and southward. Although more typically recorded in Korea during the fall migration, the individual above was photographed in the POL-north area on May 18, 2005.

Grey-spotted Flycatchers are about $14.5 \mathrm{~cm}$ in length. Their upperparts are a pale greyish-brown. Their underparts are whitish with heavy grey-brown streaks. They have a single whitish wing bar and an indistinct white eye ring. 


\section{Asian Brown Flycatcher \\ Muscicapa dauurica}

\section{Soesol-ttaksae}

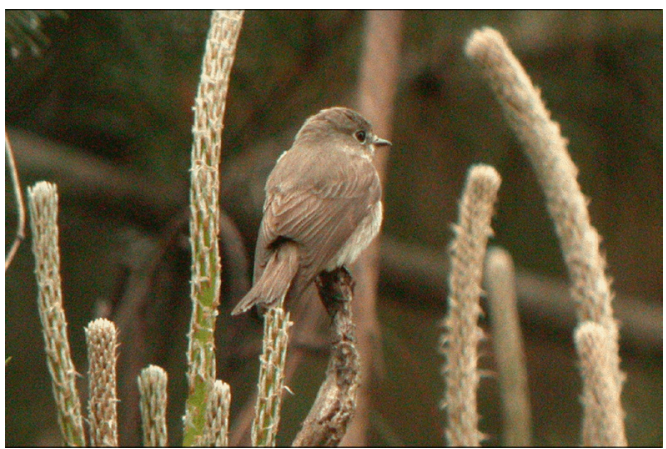

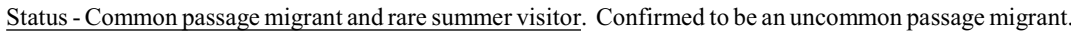

\begin{tabular}{|l|l|l|l|l|l|l|l|l|l|l|l|l|}
\hline \multicolumn{10}{|c|}{ Asian Brown Flycatcher } \\
\hline & Jan & Feb & M ar & Apr & May & Jun & Jul & Aug & Sep & Oct & Nov & Dec \\
\hline Forests & & & & & U & & & & & & & \\
\hline Wetlands & & & & & & & & & & & & \\
\hline Intertidal Zone & & & & & & & & & & & & \\
\hline Airficld & & & & & & & & & & & & \\
\hline Cantonment & & & & & & & & & & & & \\
\hline
\end{tabular}

The Asian Brown Flycatcher nests and breeds in extreme northeastern China and Russia and throughout the major Japanese islands. Their preferred habitats include open woods in lowlands and mountainsides. During migration, they occur in similar habitats as well as urban areas.

Asian Brown Flycatchers attain only $13 \mathrm{~cm}$ in length and are drab brown above. They have an obvious white eye ring, but lack any other distinct markings. On close inspection, the secondary and tertiary wing feathers often display pale edging. Their underparts vary from whitish to pale greyish-brown with indistinct spotting. 


\section{Red-throated Flycatcher}

Ficedula parva

\section{Huinkkori-ttaksae}

Not

Photographed

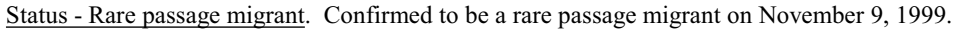

\begin{tabular}{|l|c|c|c|c|c|c|c|c|c|c|c|c|}
\hline \multicolumn{10}{|c|}{ Red-throated Flycatcher } \\
\hline & Jan & Feb & Mar & Apr & May & Jun & Jul & Aug & Sep & Oct & Nov & Dec \\
\hline Forests & & & & & & & & & & & R & \\
\hline Wetlands & & & & & & & & & & & & \\
\hline Intertidal Zone & & & & & & & & & & & & \\
\hline Airfield & & & & & & & & & & & & \\
\hline Cantonment & & & & & & & & & & & & \\
\hline
\end{tabular}

The sighting and recording of the Red-throated Flycatcher at Kunsan are relatively unusual. A single female was recorded foraging in the overgrown bottom of the abandoned tank in the POL-north area. Red-throated Flycatchers nest and breed throughout the taiga of Siberia and overwinter in southern China and southward.

Red-throated Flycatchers are small, attaining only $12 \mathrm{~cm}$ in length. The female observed was greyish-brown above and creamy-whitish beneath. It had a distinct white eye ring. The tail was black except for the white base of the outer feathers, which become oval shaped when the tail is fanned. Its foraging behavior was diagnostic. It perched low and frequently flicked its tail upwards and then fanned it downward. Presumably, the motion coupled with distinct white oval patches on the outer feathers are intended to flush insects from cover. 


\section{Blue-and-White Flycatcher \\ Cyanoptila cyanomelana}

Keunnyurisae

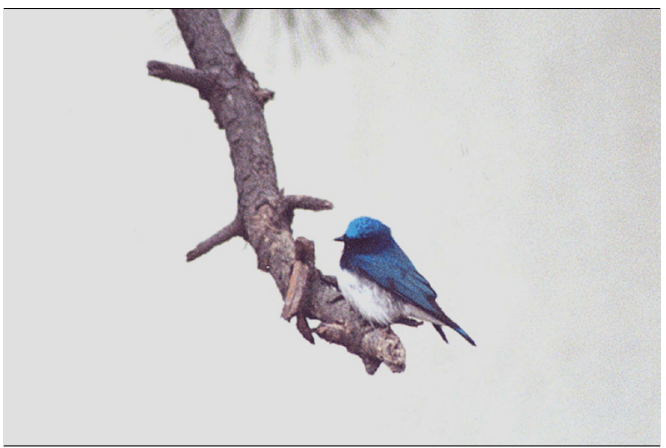

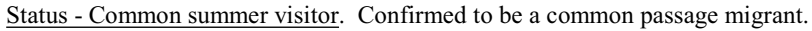

\begin{tabular}{|l|c|c|c|c|c|c|c|c|c|c|c|c|}
\hline \multicolumn{10}{|c|}{ Blue-and-White Flycatcher } \\
\hline & Jan & Feb & Mar & Apr & M ay & Jun & Jul & Aug & Sep & Oct & Nov & Dec \\
\hline Forests & & & & & & & & & & & & \\
\hline Wetlands & & & & & & & & & & & & \\
\hline Intertidal Zone & & & & & & & & & & & & \\
\hline Airfield & & & & & & & & & & & & \\
\hline Cantonment & & & & C & & & & & & & & \\
\hline
\end{tabular}

Blue-and-White Flycatchers nest and breed throughout Korea, Japan, and northeastern China. They inhabit deciduous and mixed forests at higher elevations. They prefer shady, mature forests with streams. Such habitat is not available on Kunsan AB; consequently, they are only present during migration. On migration, they visit more open woodlands including the pine grove adjacent to the billeting office and golf course clubhouse.

Blue-and-White Flycatchers attain a length of about $16.5 \mathrm{~cm}$. Male upperparts are an iridescent, glossy blue in contrast with their white lower breast, belly, and vent. The crown is an even brighter iridescent blue above a black face and upper breast. Females are a dull brown with a white throat, belly, and vent. Her wings and tail are darker brown. 


\section{Vinous-throated Parrotbill \\ Paradoxornis webbianus}

\section{Bulgenmeoriomongnuni}

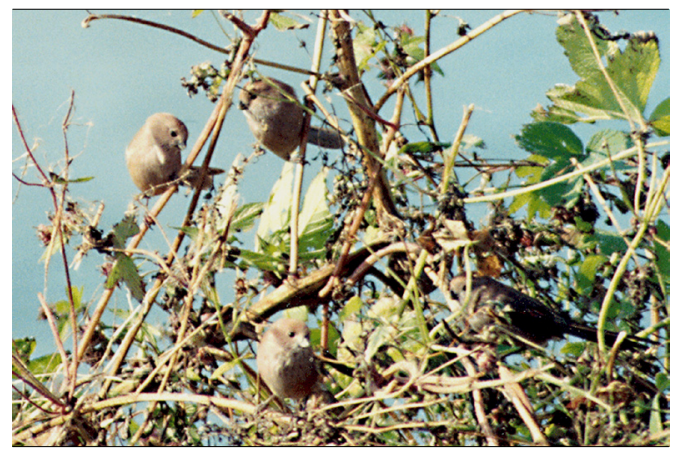

Status - Abundant resident. Confirmed to be a common resident.

\begin{tabular}{|l|c|c|c|c|c|c|c|c|c|c|c|c|}
\hline \multicolumn{10}{|c|}{ Vinous-throated Parrotbill } \\
\hline & Jan & Feb & Mar & Apr & May & Jun & Jul & Aug & Sep & Oct & Nov & Dec \\
\hline Forests & & & & & C & & & & & & & \\
\hline Wetlands & & & & & & & & & & & & \\
\hline Intertidal Zone & & & & & & & & & & & & \\
\hline Airfield & & & & C & C & U & & C & C & & C & \\
\hline Cantonment & & & & & & U & & & & & & \\
\hline
\end{tabular}

Vinous-throated Parrotbills can be locally abundant on Kunsan. They forage in flocks of 10 to 30 individuals and are more often heard than seen as they chatter their way through dense tangles of undergrowth. Often, one can be within a few feet of a flock and see only motion because of their excellent camouflage. They are most commonly found in the overgrown areas at the bases of Big and Little Coyote Hills, the CE bulk storage yard, and the reedbeds associated with the Yellow Sea shoreline.

Vinous-throated Parrotbills are small birds attaining only $13 \mathrm{~cm}$ in length. Overall, they are brown above with reddish-brown tints to their crown and wings. Beneath, they are a dull buff-brown. They have long tails and a stubby, short, black bill.

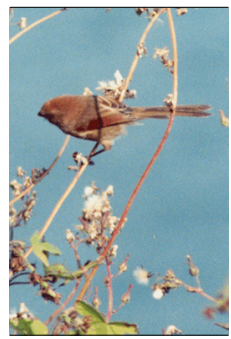




\section{Varied Tit \\ Poecile varius (formerly Parus varius)}

\section{Gonjulbagi}

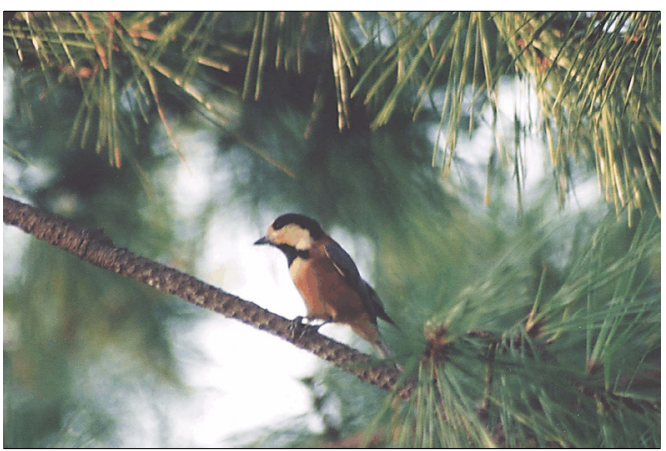

Status - Common resident. Confirmed to be an uncommon winter visitor.

\begin{tabular}{|l|l|l|l|l|l|l|l|l|l|l|l|l|}
\hline \multicolumn{10}{|c|}{ Varied Tit } \\
\hline & Jan & Feb & M ar & Apr & M ay & Jun & Jul & Aug & Sep & Oct & Nov & Dec \\
\hline Forests & & & & & & & & & & & U & \\
\hline Wetlands & & & & & & & & & & & & \\
\hline Intertidal Zone & & & & & & & & & & & & \\
\hline Airfield & & & & & & & & & & & & \\
\hline Cantonment & & & & & & & & & & & & \\
\hline
\end{tabular}

Varied Tits prefer mature forests of mixed deciduous and conifer trees with a thick undergrowth of shrubs. They seem to avoid areas of dense human occupation. Because their preferred habitat is not available on Kunsan $\mathrm{AB}$, they are only incidentally encountered on base and then usually during the winter months. Then they can be observed foraging with mixed flocks of Great and Marsh Tits (P. major and P. palustris, respectively).

The Varied Tit is comparable in size to the Great Tit, reaching $14 \mathrm{~cm}$ in length. Like the other species of tits, they have a black cap and throat and their wings and tail are grey-blue. They have a creamy-white face, nape patch, and upper breast, but their upper back and undersides are rusty brown. They are the only brightly colored tit found in Korea. (Varied Tit photographed on COMFLEACT Chinhae.) 


\section{Marsh Tit \\ Poecile palustris (formerly Parus palustris)}

Soebaksae

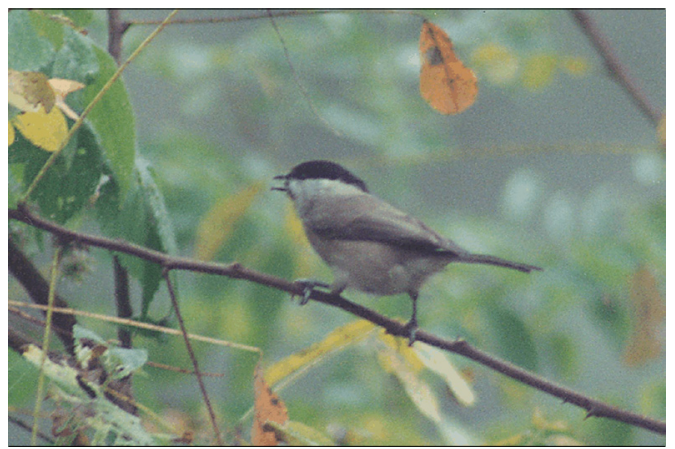

Status - Common resident. Confirmed to be an uncommon resident.

\begin{tabular}{|l|c|c|c|c|c|c|c|c|c|c|c|c|}
\hline \multicolumn{10}{|c|}{ Marsh Tit } \\
\hline & Jan & Feb & Mar & Apr & M ay & Jun & Jul & Aug & Sep & Oct & Nov & Dec \\
\hline Forests & & & U & & & & & & & & & \\
\hline Wetlands & & & & & & & & & & & & \\
\hline Intertidal Zone & & & & & & & & & & & & \\
\hline Airfield & & & & & & & & & & & & \\
\hline Cantonment & U & & & & & & & & U & & & \\
\hline
\end{tabular}

Marsh Tits inhabit mature deciduous and mixed forests in the summer on slopes up to the tree line. In winter, they move down to lower elevations and occur in more open woodlands and thickets. On Kunsan, they are often in mixed flocks with Great Tits (P. major) in the cantonment and POL-north areas.

Similar in size to Coal Tits ( $P$. ater), Marsh Tits are small, attaining only $11 \mathrm{~cm}$ in length. The sexes are similar. Like the other tits, the Marsh Tit has a black cap, but it is solid without a crown stripe or nape patch. They also have small black throat patches, but lack a bib. Their backs, wings, and tail are unmarked grey. Their undersides are greyish-white.

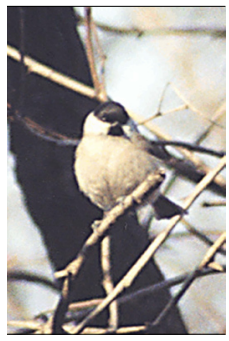




\section{Coal Tit \\ Poecile ater (formerly Parus ater)}

Jinbaksae

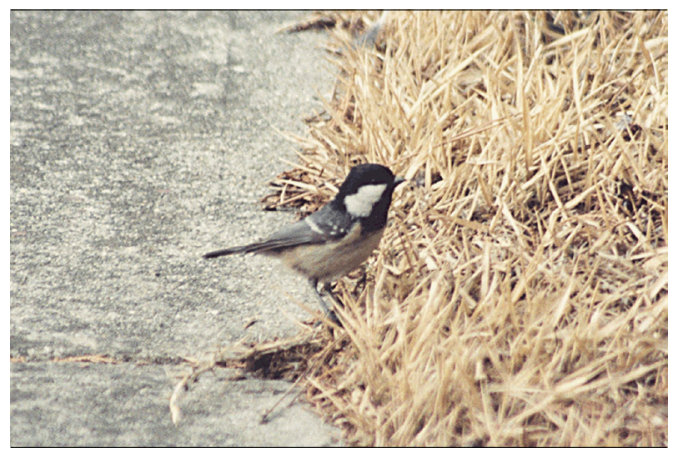

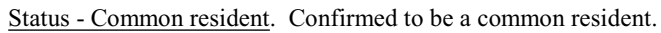

\begin{tabular}{|l|c|c|c|c|c|c|c|c|c|c|c|c|}
\hline \multicolumn{10}{|c|}{ Coal Tit } \\
\hline & Jan & Feb & Mar & Apr & May & Jun & Jul & Aug & Sep & Oct & Nov & Dec \\
\hline Forests & & C & C & & C & & & & & C & U & \\
\hline Wettands & & & & & & & & & & & & \\
\hline Intertidal Zone & & & & & & & & & & & & \\
\hline Airfield & & & & & & & & & & & & \\
\hline Cantonment & & U & U & & & & & & & & U & \\
\hline
\end{tabular}

Coal Tits are most commonly seen on Kunsan during the non-breeding season in the POL-north area and the pine stands of the cantonment area. Presumably they migrate to conifer forests in the higher elevations to nest and breed. Following the breeding season, they descend to lower elevations.

Coal Tits are smallest tits to occur on Kunsan and seldom exceed $11 \mathrm{~cm}$ in length. They have a black crested head with an elongated white nap. Their bold black throat extends into a bib that highlights their large white cheeks and ends abruptly on the upper breast. Their backs are bluish-grey with blackish wings. Rows of white spots on the upper wing sometimes converge to make two wing bars.

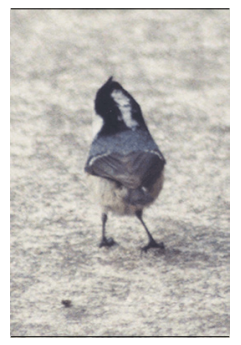




\section{Great Tit}

Poecile major (formerly Parus major)

\section{Balsae}

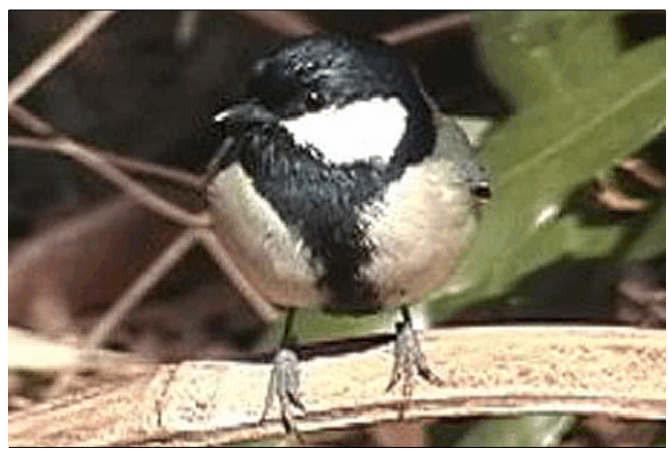

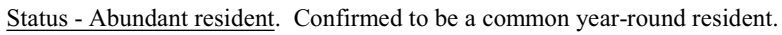

\begin{tabular}{|l|c|c|c|c|c|c|c|c|c|c|c|c|}
\hline \multicolumn{10}{|c|}{ Great Tit } \\
\hline & Jan & Feb & M ar & Apr & M ay & Jun & Jul & Aug & Sep & oct & Nov & Dec \\
\hline Forests & C & C & C & C & C & C & U & C & C & C & C & C \\
\hline Wetlands & & & & & & & & & & & & \\
\hline Intertidal Zone & & & & & & & & & & & & \\
\hline Airfield & & U & & U & U & U & & C & U & U & U & C \\
\hline Cantonment & C & C & C & C & C & C & & C & C & C & C & \\
\hline
\end{tabular}

Great Tits occur in all of the upland, dry habitats on Kunsan. Small flocks live, forage, and nest in the landscape plantings of the cantonment area. They are often in the company of Marsh and Coal Tits (P. palustris and P. ater, respectively).

The Great Tit is the largest of the tits found on Kunsan, approaching $14.5 \mathrm{~cm}$ in length. Their black cap and throat surrounds their white cheek. A black line extends from the throat down the center of the white breast and belly to the vent. The male's line is noticeably broader than the females. Their backs are bluish-grey highlighted with olive on the upper shoulders. The wings are dark grey with a single wing bar and white edging on the primary and secondary wing feathers. (Top photograph by Robert Dalzell.)

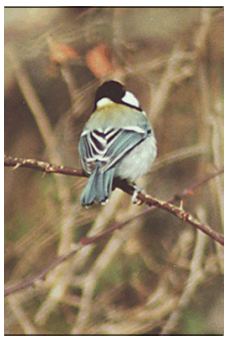




\section{Rustic Bunting}

Emberiza rustica

\section{Ssuksae}

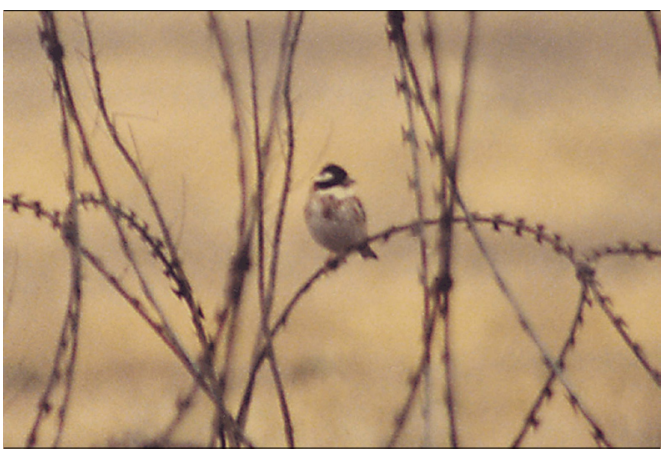

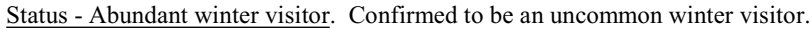

\begin{tabular}{|l|c|c|c|c|c|c|c|c|c|c|c|c|}
\hline \multicolumn{10}{|c|}{ Rustic Bunting } \\
\hline & Jan & Feb & Mar & Apr & May & Jun & Jul & Aug & Sep & Oct & Nov & Dec \\
\hline Forests & & & & & & & & & & & & C \\
\hline Wetlands & & & & & & & & & & & & \\
\hline Intertidal Zone & & & & & & & & & & & & \\
\hline Airfield & & & & & & & & & & & & R \\
\hline Cantonment & & & & & & & & & & & & \\
\hline
\end{tabular}

Rustic Buntings nest and breed throughout the taiga of Siberia and overwinter throughout Korea, Japan, and eastern China. In Korea, they frequent the undergrowth associated with lowland woods, paddy field berms, and river banks. On Kunsan, they are normally encountered foraging with flocks of Tree Sparrows (Passer montanus) or Yellow-throated Buntings (E. elegans) near the base of Little Coyote Hill or along the edge of the POL-north area.

Male Rustic Buntings display a distinctive black head with a small crest and a bright white eyebrow and throat. Their backs are reddish brown with black streaks. The undersides are greyish with chestnut-colored flanks and a central splotch on the breast. In the deepest months of winter, their head fades from black to brown with reddish-brown cheek and shoulder patches. Female plumage closely resembles that of the winter male. 


\section{Yellow-throated Bunting}

Emberiza elegans

\section{Norangteongmetse}

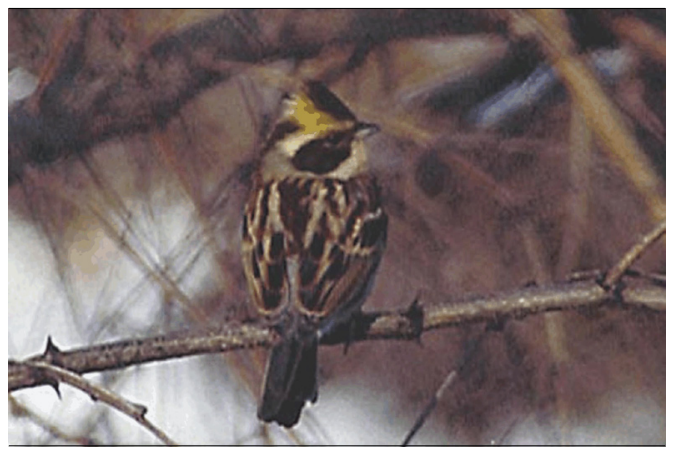

Status - Common resident. Confirmed to be a common winter visitor.

\begin{tabular}{|l|c|c|c|c|c|c|c|c|c|c|c|c|}
\hline \multicolumn{10}{|c|}{ Yellow-throated Bunting } \\
\hline & Jan & Feb & M ar & Apr & M ay & Jun & Jul & Aug & Sep & oct & Nov & Dec \\
\hline Forests & & C & & & & & & & & & C & C \\
\hline Wetlands & & & & & & & & & & & & \\
\hline Intertidal Zone & & & & & & & & & & & & \\
\hline Airfield & & U & & & & & & & & & U & U \\
\hline Cantonment & C & & & & & & & & & & & C \\
\hline
\end{tabular}

Yellow-throated Buntings also frequent the undergrowth of open forests and forest edge. They nest and breed in northeastern China and adjacent Russia. Many overwinter in Japan and along the coast of southeastern China. In Korea, Yellow-throated Buntings are year-round residents. On Kunsan, they are most commonly found during the winter months foraging in the undergrowth near the base of Little Coyote Hill and around the edges of the POL-north area. Characteristically, they usually stay well under cover.

Male Yellow-throated Buntings have a conspicuous yellow face and throat with a black face mask and crest. Their backs and wings are brown streaked with black. They have two white wing bars. The undersides are whitish with chestnut-colored streaks on the flanks and an obvious black, triangular breast patch. The female is duller than the male and lacks the black face mask, crown, and breast patch. 


\section{Oriental Greenfinch}

Carduelis sinica

\section{Bangulsae}

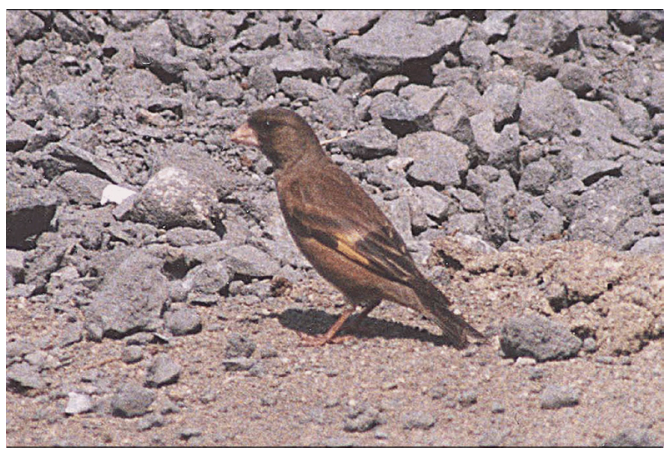

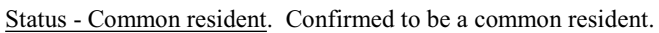

\begin{tabular}{|l|c|c|c|c|c|c|c|c|c|c|c|c|}
\hline \multicolumn{10}{|c|}{ Oriental Greenfinch } \\
\hline & Jan & Feb & Mar & Apr & May & Jun & Jul & Aug & Sep & Oct & Nov & Dec \\
\hline Forests & & U & & & C & & & & & & & \\
\hline Wetlands & & & & & & & & & & & & \\
\hline Intertidal Zone & & & & & & & & & & & & \\
\hline Airfield & C & C & & & C & C & & U & & C & C & C \\
\hline Cantonment & C & C & C & C & C & C & & U & U & U & C & C \\
\hline
\end{tabular}

Oriental Greenfinches likely nest and breed on Kunsan AB. They can be observed in small flocks in the open woodland settings of Little and Big Coyote Hills, the POL-north area, and most commonly in the cantonment area of the base.

Oriental Greenfinches are medium-sized finches attaining a length of about 14.5 $\mathrm{cm}$. The male is greenish-brown with a grey head. The wings and tail are blackish, but the base of the outer tail feathers and the base of the wing flight feathers are bright yellow. These yellow patches are conspicuous at rest and especially in flight. The female resembles the male but is more brown than green. Both sexes have a bright pink bill and legs.

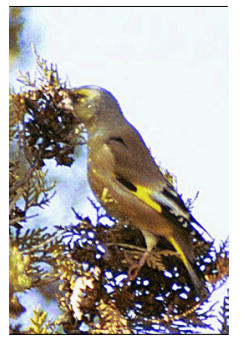




\section{Siskin \\ Carduelis spinus}

\section{Geomeunmeoribangulsae}

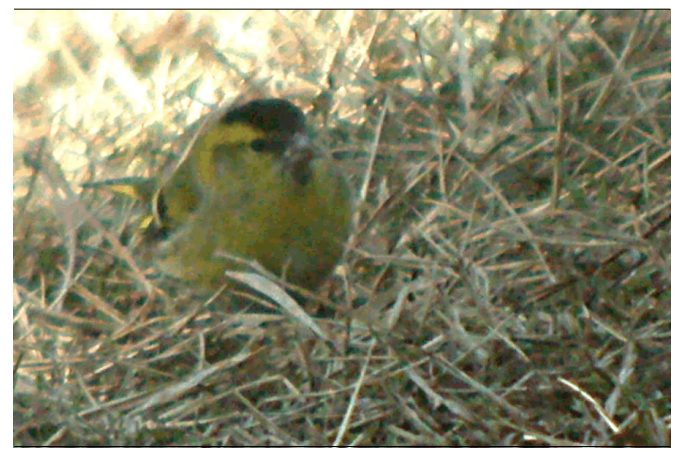

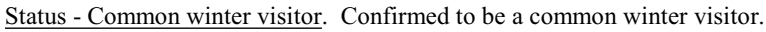

\begin{tabular}{|l|c|c|c|c|c|c|c|c|c|c|c|c|}
\hline \multicolumn{10}{|c|}{ Sisken } \\
\hline & Jan & Feb & Mar & Apr & M ay & Jun & Jul & Aug & Sep & Oct & Nov & Dec \\
\hline Forests & & C & & & & & & & & & & \\
\hline Wetlands & & & & & & & & & & & & \\
\hline Intertidal Zone & & & & & & & & & & & & \\
\hline Airfield & & & & & & & & & & & & \\
\hline Cantonment & & C & & & & & & & & & & \\
\hline
\end{tabular}

Siskins breed and nest in northeastern China, Russia, and the northern Japan. They spend the non-breeding season throughout Korea, southern Japan, and eastern China. On Kunsan, they occur in small flocks foraging in the lawns of Gunsmoke Hill and the officers' housing areas for seeds.

Siskins are small attaining only $12.5 \mathrm{~cm}$ in length. The males sport a black crown over a bright yellow face and breast. The undersides are white with black streaks. Their dark yellow-green back with black streaks grades into blackish wings with two yellow wing bars. The female (at right) is more streaked than the male and lacks the black cap and bright yellow coloring. Instead, her overall coloration is more greyish with black streaks.

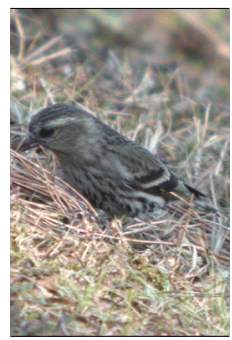




\section{Brambling \\ Fringilla montifringilla}

\section{Doesae}

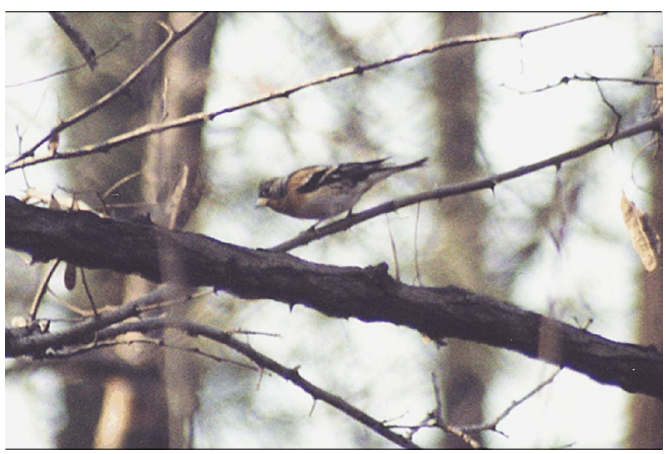

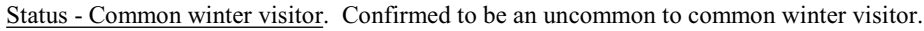

\begin{tabular}{|l|c|c|c|c|c|c|c|c|c|c|c|c|}
\hline \multicolumn{10}{|c|}{ Brambling } \\
\hline & Jan & Feb & M ar & Apr & M ay & Jun & Jul & Aug & Sep & Oct & Nov & Dec \\
\hline Forests & & & & & & & & & & U & & \\
\hline Wetlands & & & & & & & & & & & & \\
\hline Intertidal Zone & & & & & & & & & & & & \\
\hline Airfield & & & & & & & & & & & & \\
\hline Cantonment & & C & & & & & & & & & & \\
\hline
\end{tabular}

Brambling breed through the taiga of Siberia and overwinter in northeastern China, Russia, Japan, Korea, and eastern China. They can become locally abundant in Korea during the winter months. On the Kunsan $\mathrm{AB}$, they are common but never numerous in the vicinity of Wolf Pack Park.

Brambling are small finches reaching about $16 \mathrm{~cm}$ in length. More colorful during the breeding season, in winter they have grey heads with two black stripes from the crown to the nape. The back and breast are a rusty brown - the back displays some grey scaling. The tail and wings are black with an evident wing bar. The predominantly white undersides have a pale wash of rust. 


\section{Common Crossbill}

\section{Loxia curvirostra}

\section{Soljatsae}

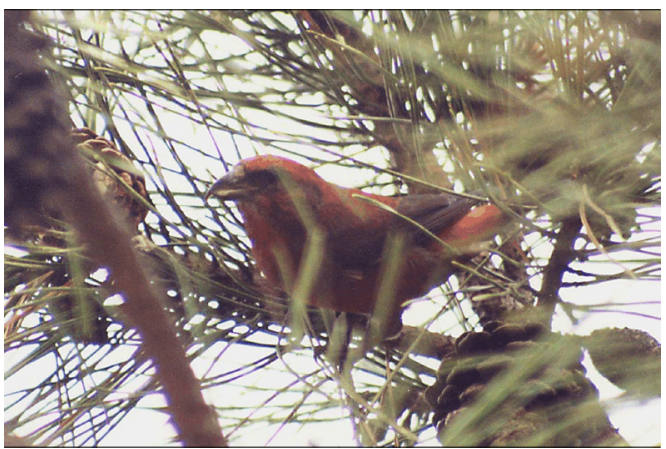

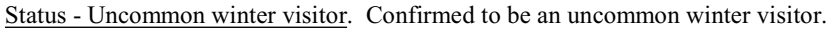

\begin{tabular}{|l|l|l|l|l|l|l|l|l|l|l|l|l|}
\hline \multicolumn{10}{|c|}{ Common Crossbill } \\
\hline & Jan & Feb & Mar & Apr & May & Jun & Jul & Aug & Sep & Oct & Nov & Dec \\
\hline Forests & & & & & & & & & & & & \\
\hline Wetlands & & & & & & & & & & & & \\
\hline Intertidal Zone & & & & & & & & & & & & \\
\hline Airfield & & & & & & & & & & & & \\
\hline Cantonment & & U & U & & & & & & & & & \\
\hline
\end{tabular}

Common Crossbills are year-round residents and breed through the taiga of Siberia and northeastern China. However, some migrate southward to overwinter in Korea and Japan. They prefer coniferous forests where they are adept at extracting pine seeds from cones with their uniquely crossed bills. On Kunsan, they can sometimes be observed foraging in the mature pines associated with Gunsmoke Hill, the billeting office, and the golf course clubhouse.

Common Crossbills are average-sized finches reaching about $16.5 \mathrm{~cm}$ in length. Overall, the males are red with blackish-brown wings and tails. The females are greyish-brown with a washing of yellow highlights on the crown and back. She has a yellow rump and blackish-brown wings and tails. The diagnostic field mark is the black crossed bill. 


\section{Hawfinch \\ Coccothraustes coccothraustes}

\section{Kongsae}

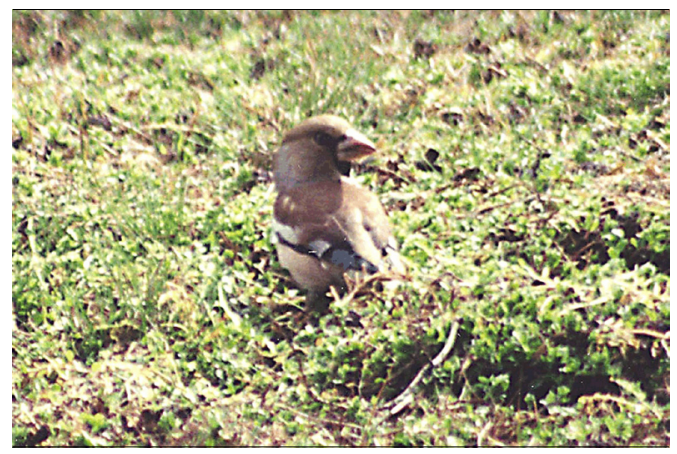

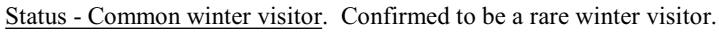

\begin{tabular}{|l|c|c|c|c|c|c|c|c|c|c|c|c|}
\hline \multicolumn{10}{|c|}{ Hawfinch } \\
\hline & Jan & Feb & M ar & Apr & May & Jun & Jul & Aug & Sep & Oct & Nov & Dec \\
\hline Forests & & & & & & & & & & & & \\
\hline Wetlands & & & & & & & & & & & & \\
\hline Intertidal Zone & & & & & & & & & & & & \\
\hline Airfield & & & & & & & & & & & & \\
\hline Cantonment & & R & R & & & & & & & & & \\
\hline
\end{tabular}

Hawfinches often occupy lawns, gardens, and parks. They are never numerous on Kunsan and are most often in the company of mixed flocks of Oriental Greenfinches (C. sinica) and Siskins (C. spinus). They can be seen in the short-mowed winter lawns in the vicinity of the billeting office and officers' housing areas.

Hawfinches are small, stocky finches attaining about $18 \mathrm{~cm}$ in length. Their heads are golden-brown with a grey nape separating a darker brown back ending with a white-tipped tail. The undersides are a buff-brown. A single broad white wing bar and glossy blue secondaries highlight the wings. Black lores and throat surround a massive bill that is blue-black in the spring but turns to a yellowish pink in the fall. In flight, conspicuous white wing bars and white tipped tail are good field marks. The sexes are similar except the female is duller in color. 


\section{Tree Sparrow}

Passer montanus

Chamsae

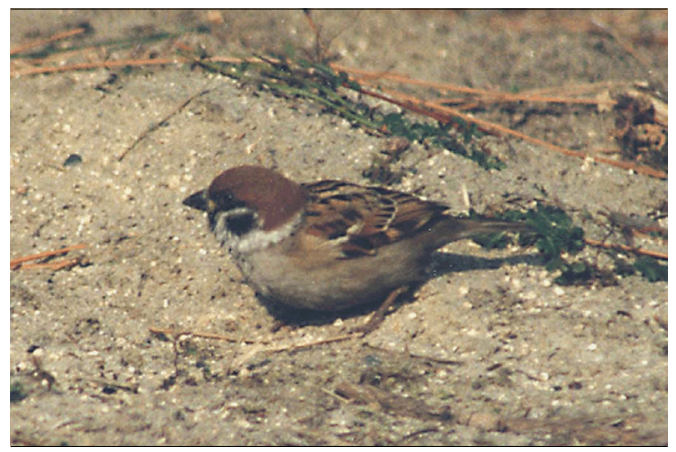

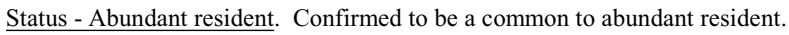

\begin{tabular}{|l|c|c|c|c|c|c|c|c|c|c|c|c|}
\hline \multicolumn{10}{|c|}{ Tree Sparrow } \\
\hline & Jan & Feb & M ar & Apr & M ay & Jun & Jul & Aug & Sep & Oct & Nov & Dec \\
\hline Forests & & U & U & & C & U & & & & & & \\
\hline Wetlands & & & & & & & & & & & & \\
\hline Intertidal Zone & & & & & & & & & & & & \\
\hline Airfield & & C & C & C & C & C & C & C & C & A & c & C \\
\hline Cantonment & C & C & C & C & C & C & C & C & c & & c & \\
\hline
\end{tabular}

Tree Sparrows are well adapted to human habitation, thriving in urban, suburban, and agricultural environments. They are very common in the cantonment area of Kunsan AB. They prefer areas where grasses have become entwined in wire fences or concertina wire and provide cover. During the non-breeding season, they aggregate into flocks of 50 to 60 individuals as they forage along fence lines and overgrown ditches.

Both sexes of the Tree Sparrow are alike. The head is dark brown with a white line forming a collar around the nape. The face is white with a diagnostic black spot on the cheek. Their backs and wings are brown and streaked with black. They have two thin, white wing bars. Their undersides are greyish.

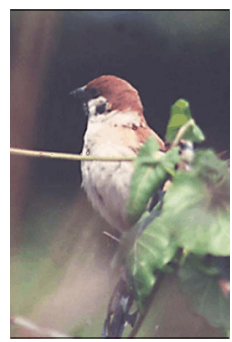




\section{Grey Starling}

Sturnus cineraceus

\section{Jjireuregi}

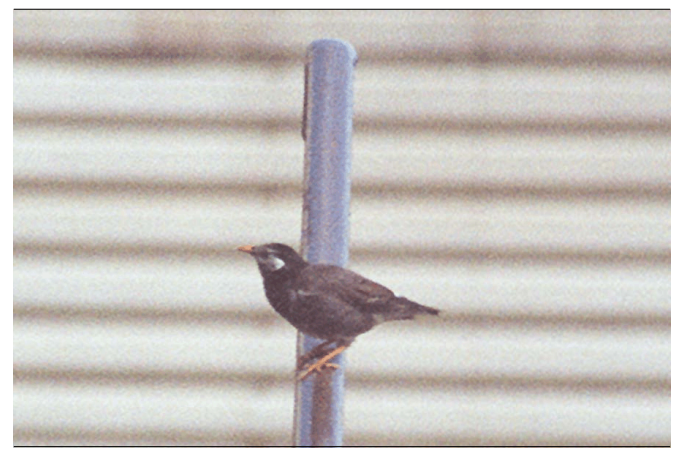

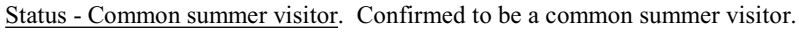

\begin{tabular}{|l|c|c|c|c|c|c|c|c|c|c|c|c|}
\hline \multicolumn{10}{|c|}{ Grey Starling } \\
\hline & Jan & Feb & Mar & Apr & May & Jun & Jul & Aug & Sep & Oct & Nov & Dec \\
\hline Forests & & & U & & U & & & & & & & \\
\hline Wettands & & & & & & & & & & & & \\
\hline Intertidal Zone & & & & & & & & & & & & \\
\hline Airfield & & & U & & C & A & U & & & & & \\
\hline Cantonment & & & C & C & C & C & c & c & & & & \\
\hline
\end{tabular}

Grey Starlings breed as far north as northeastern China and overwinter through southern China. In between, some are year-round residents of Korea and Japan. They are well adapted to urban and suburban environments and are common in city parks, gardens, and residential areas. At Kunsan $\mathrm{AB}$, they are most often encountered in the cantonment area.

Grey Starlings are short-tailed, stocky birds attaining a length of about $24 \mathrm{~cm}$. The top and back of their heads, neck, and breast are black, setting off their sometimes streaked white face. Their upperparts are greyish-brown with only slightly paler underparts. Good field marks include their orange bill and legs and an obvious white rump patch visible in flight.

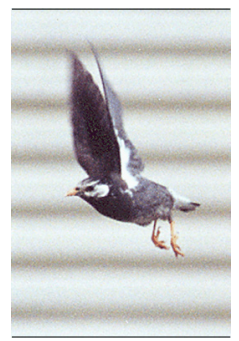




\section{Black-naped Oriole \\ Oriolus chinensis}

\section{Kkeokkori}

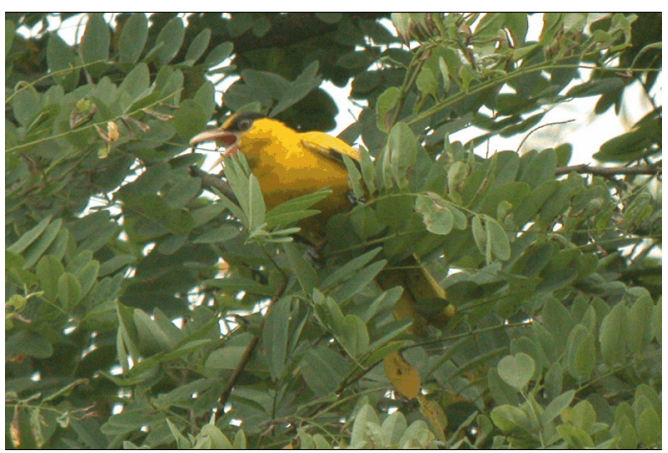

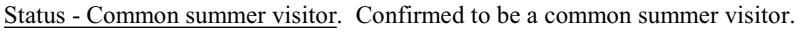

\begin{tabular}{|l|l|l|l|l|l|l|l|l|l|l|l|l|}
\hline \multicolumn{10}{|c|}{ Black-naped Oriole } \\
\hline & Jan & Feb & Mar & Apr & M ay & Jun & Jul & Aug & Sep & Oct & Nov & Dec \\
\hline Forests & & & & & C & & & & U & & & \\
\hline Wetlands & & & & & & & & & & & & \\
\hline Intertidal Zone & & & & & & & & & & & & \\
\hline Airfield & & & & & & & & & & & & \\
\hline Cantonment & & & & & & & & & & & & \\
\hline
\end{tabular}

Black-naped Orioles breed throughout Korea and China. They overwinter in southeastern Asia and Malaysia. On Kunsan AB, they are typically found in the upland deciduous forest of the POL-north area and it is likely they nest there. They are more often heard than seen. Their scold is unique and easy to identify, as it is similar to a North American Catbird's mimic of a cat's call.

Black-naped Orioles are striking, unmistakable, bright yellow birds with a black mask, nape, and tail. Their bills are bright pink, and their legs are black. A medium-sized bird, they reach $26 \mathrm{~cm}$ in length.

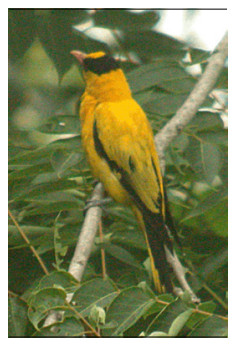




\section{Black-billed Magpie}

Pica pica

\section{Kkachi}

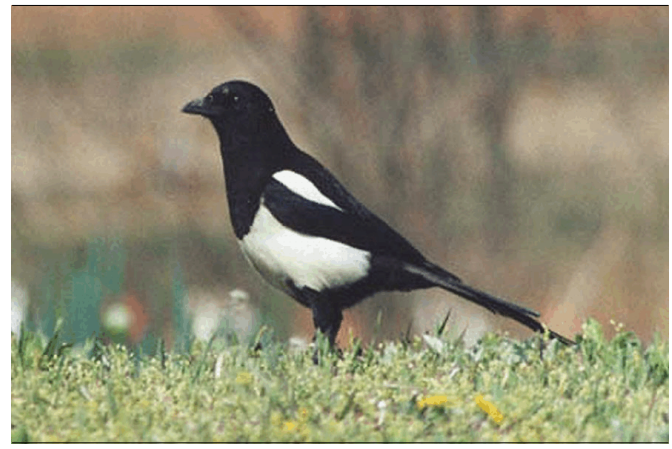

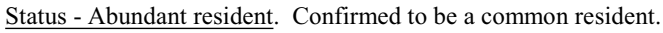

\begin{tabular}{|l|c|c|c|c|c|c|c|c|c|c|c|c|}
\hline \multicolumn{10}{|c|}{ Black-billed Magpie } \\
\hline & Jan & Feb & M ar & Apr & M ay & Jun & Jul & Aug & Sep & Oct & Nov & Dec \\
\hline Forests & C & C & C & & C & C & C & C & C & c & C & c \\
\hline Wetlands & & & & & & & & & & & & \\
\hline Intertidal Zone & & & & & & & & & & & & \\
\hline Airfield & C & C & C & C & C & C & C & C & C & C & C & C \\
\hline Cantonment & C & C & C & C & C & C & C & C & C & C & C & C \\
\hline
\end{tabular}

Black-billed Magpies are one of the most common birds found on Kunsan AB and are present in all of the upland habitats. They are loud and raucous and sometimes form flocks of 20 to 30 individuals. They breed on base, and their large nests of sticks can be seen on antenna towers, poles, and in trees. Typically they forage for food on the ground. They are aggressive birds and can often be observed scrapping amongst themselves.

Black-billed Magpies are relatively large birds reaching $46 \mathrm{~cm}$ in length. They have black upperparts, throat, breast, and vent area. Their shoulders and belly are white. They have a long, wedge-shaped tail that, like their wings, is glossed with green, blue, or purple. Their bills and legs are black.

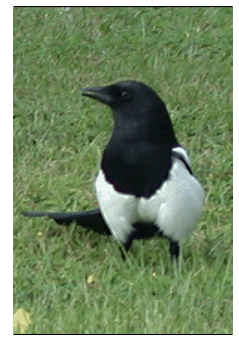




\section{Daurian Jackdaw}

Corvus dauuricus

\section{Galkkamagwi}

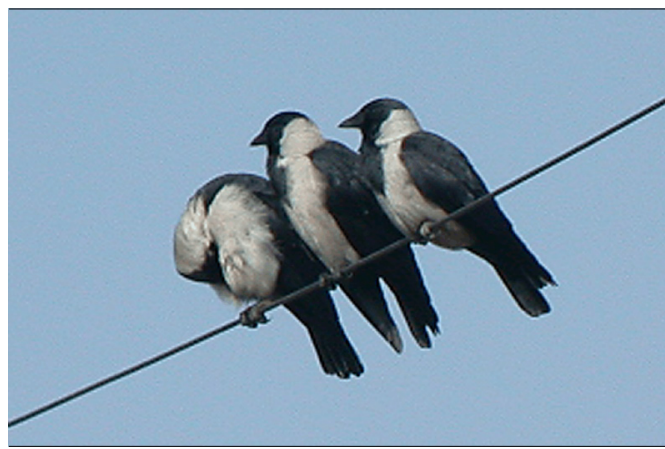

Status - Uncommon winter visitor. Confirmed to be a common winter visitor.

\begin{tabular}{|l|c|c|c|c|c|c|c|c|c|c|c|c|}
\hline \multicolumn{10}{|c|}{ Daurian Jackdaw } \\
\hline & Jan & Feb & Mar & Apr & M ay & Jun & Jul & Aug & Sep & Oct & Nov & Dec \\
\hline Forests & & & & & & & & & & & & C \\
\hline Wetlands & & & & & & & & & & & & \\
\hline Intertidal Zone & & & & & & & & & & & & \\
\hline Airfield & & & & & & & & & & & & U \\
\hline Cantonment & A & & & & & & & & & & & \\
\hline
\end{tabular}

Jackdaws nest and breed throughout central Asia and are year-round residents of northeastern China. They prefer open agricultural country where they forage for earthworms. Migrating birds overwinter in southern South Korea and east-central China. Jackdaws commonly associate with large flocks of Rooks during the winter months. The author estimates that Jackdaws make up only 2 to $5 \%$ of the large mixed flocks.

Jackdaws are small crows attaining only $33 \mathrm{~cm}$ in length and occur in two color phases. The dark phase is entirely black except for an often imperceptible grey nape. The light phase has a black face, breast, back, wings, and tail with a white nape, lower breast, and belly (as pictured above). Both phases coexist in the same flock.

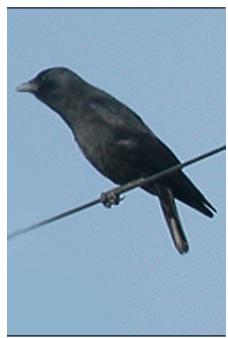




\section{Rook \\ Corvus frugilegus}

Tte-kkamagwi

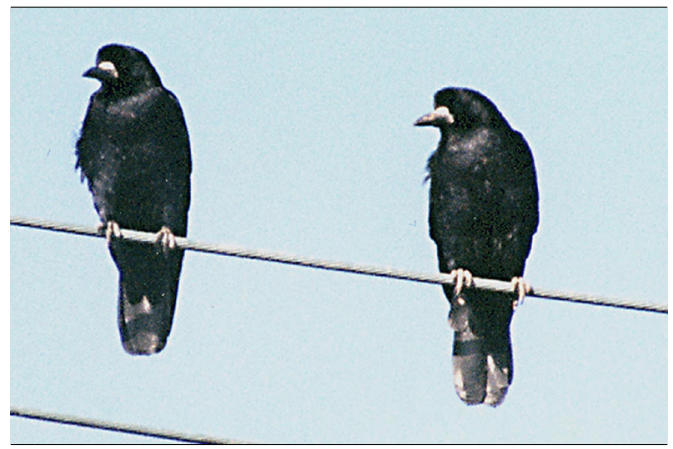

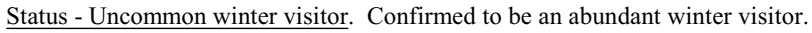

\begin{tabular}{|l|c|c|c|c|c|c|c|c|c|c|c|c|}
\hline \multicolumn{10}{|c|}{ Rook } \\
\hline & Jan & Feb & Mar & Apr & May & Jun & Jul & Aug & Sep & Oct & Nov & Dec \\
\hline Forests & A & & & & & & & & & & A & C \\
\hline Wetlands & & & & & & & & & & & & \\
\hline Intertidal Zone & A & & & & & & & & & & & \\
\hline Airfield & A & C & & & & & & & & & & A \\
\hline Cantonment & A & C & & & & & & & & & A & A \\
\hline
\end{tabular}

Rooks nest and breed throughout eastern China extending northward into Russia. They overwinter in southern South Korea, southern Japan, and southeastern China. The Kunsan area is an age-old wintering ground for Rooks. They congregate locally in flocks that number well into the thousands. While in the Kunsan area, they frequent the tidal flats and rice paddies for food. During midday, large flocks, or kettles, of Rooks can be seen riding the thermal currents. Around dusk, they congregate in large communal roosts, often on base. From November through January, Rooks pose a significant BASH risk to aviation traffic in and around Kunsan.

Rooks are relatively large, reaching a length of about $47 \mathrm{~cm}$, or slightly smaller than a Carrion Crow. Their plumage is black. Their bill is greyish. Good field marks include the whitish area of bare skin at the base of the bill and the prominent, steep forehead. 


\section{Carrion Crow}

Corvus corone

\section{Kkamagwi}

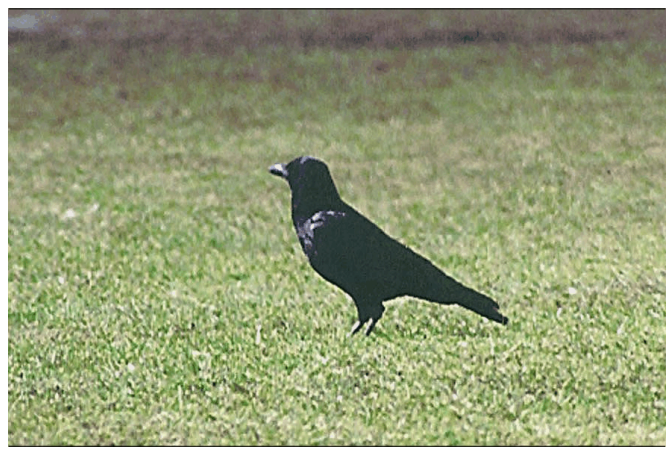

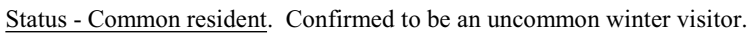

\begin{tabular}{|l|c|c|c|c|c|c|c|c|c|c|c|c|}
\hline \multicolumn{10}{|c|}{ Carrion Crow } \\
\hline & Jan & Feb & M ar & Apr & M ay & Jun & Jul & Aug & Sep & Oct & Nov & Dec \\
\hline Forests & & U & R & & & & & & & & & \\
\hline Wetlands & & & & & & & & & & & & \\
\hline Intertidal Zone & & & & & & & & & & & & \\
\hline Airfield & & U & & & & & & & & & & \\
\hline Cantonment & & U & & & & & & & & & & \\
\hline
\end{tabular}

Carrion Crows are inland rather than coastal species, hence their uncommonness in the vicinity of Kunsan AB. Generally they are more common in the higher elevations during the summer and move to the lowlands during the winter. They have adapted well to areas of human habitation, especially agricultural areas.

The Carrion Crow is relatively large, reaching $50 \mathrm{~cm}$ in length. They have black plumage that has a glossy iridescence ranging from purplish to greenish. Their smoothly tapering forehead is a good field mark. 


\section{BASH (Bird Aircraft Strike Hazards)}

Table 1 lists all of the bird species confirmed to occur on Kunsan AB. A subjective scale was used to rank each bird species identified according to the potential hazard it poses to aircraft operations. The ranking has four categories, ranging from "high" for the greatest hazard to "slight" for the least hazard.

Somewhat more than one-half(60 species) of the species are classified as either "high," "moderate," or "low" BASH risks. Birds assigned a high hazard ranking (1) commonly occur on the airfield or in the intertidal zone beneath the runway approach, (2) prefer grassland and/or wetland habitats occurring on the airfield, (3) are of large mass, (4) tend to congregate in flocks, and (5) demonstrate unexpected or unpredictable behavior when subjected to aircraft operations.

Slightly less than one-half (56 species) of the species are classified as "slight" BASH risks because they either do not occur in the habitats associated with the airfield environment or their behavioral characteristics would lead them to cower under cover of the grasses rather than take flight. Also in this category are birds that are so rare in the vicinity of the base that a chance encounter with aircraft operations would be exceedingly unlikely.

Table 1. Habitats and Subjective BASH Risks for Birds Found on Kunsan AB

(Species protected by the ROK are highlighted in yellow)

\begin{tabular}{|c|c|c|}
\hline Species & Typical Habitat or Location & $\begin{array}{c}\text { BASH } \\
\text { Risk }\end{array}$ \\
\hline \multicolumn{3}{|l|}{ Cormorants (Phalacrocoracidae) } \\
\hline Great Cormorant (Phalacrocorax carbo) & Occur along rocky extension of Big Coyote Hill. & Moderate \\
\hline \multicolumn{3}{|l|}{ Herons and Bitterns (Ardeidae) } \\
\hline Grey Heron (Ardea cinerea) & Year-round resident, tidal flats and airfield drainage ditches. & High \\
\hline Cattle Egret (Bubulcus ibis) & Airfield grasslands primarily during August and September. & High \\
\hline Striated Heron (Butorides striatus) & Airfield wetlands during migration. & High \\
\hline Great Egret (Ardea alba) & Tidal flats and airfield drainage ditches. & Moderate \\
\hline Little Egret (Egretta garzetta) & Tidal flats. & Moderate \\
\hline Intermediate Egret (Egretta intermedia) & Tidal flats. & Moderate \\
\hline Black-crowned Night Heron (Nycticorax nycticorax) & Spring Nests on Little Coyote; Fall roosts in POL-north. & High \\
\hline \multicolumn{3}{|l|}{ Ibises and Spoonbills (Threskiornithidae) } \\
\hline Eurasian Spoonbill (Platalea leucorodia) & Uncommon feeder in Intertidal Zone near Big Coyote Hill. & Low \\
\hline \multicolumn{3}{|l|}{ Geese and Ducks (Anatidae) } \\
\hline Northern Pintail (Anas acuta) & Less common member of mixed duck flocks along intertidal zone. & Low \\
\hline Common Teal (Anas crecca) & Freshwater marshes and drainages, CE bulk storage yard. & Slight \\
\hline Eurasian Wigeon (Anas penelope) & Less common member of mixed duck flocks along intertidal zone. & Low \\
\hline
\end{tabular}




\begin{tabular}{|c|c|c|}
\hline Species & Typical Habitat or Location & $\begin{array}{c}\text { BASH } \\
\text { Risk }\end{array}$ \\
\hline \multicolumn{3}{|l|}{ Geese and Ducks - cont. } \\
\hline Mallard (Anas platyrhynchos) & Winter resident offshore shoals and tide line. & Low \\
\hline Spot-billed Duck (Anas poecilorhyncha) & Airfield drainage ditches, offshore shoals, and tide line. & High \\
\hline Gadwall (Anas strepera) & Less common member of mixed duck flocks along intertidal zone. & Low \\
\hline Red-breasted Merganser (Mergus serrator) & Winter resident offshore shoals and tide line. & Low \\
\hline Common Shelduck (Tadorna tadorna) & Abundant winter resident offshore and tide line. & Low \\
\hline \multicolumn{3}{|l|}{ Hawks and Eagles (Accipitridae) } \\
\hline Eurasian Sparrowhawk (Accipiter nisus) & Dead specimen at corner of 10 th Street and Avenue C (3/24/02). & Low \\
\hline Chinese Sparrowhawk (Accipiter soloensis) & North POL area and along seawall. & Low \\
\hline Common Buzzard (Buteo buteo) & Over Little Coyote/Haji Village. & Low \\
\hline Peregrine Falcon (Falco peregrinus) & Observed eating fish and ducks near Big Coyote Hill. & Low \\
\hline Eurasian Hobby (Falco subbuteo) & Observed along KAL taxiway and adjacent pines, cantonment. & Low \\
\hline Common Kestrel (Falco tinnunculus) & Year-round resident over Little Coyote and airfield. & Moderate \\
\hline \multicolumn{3}{|l|}{ Pheasants, Partridges, and Quail (Phasianidae) } \\
\hline Japanese Quail (Coturnix japonica) & Grasslands southeast of RNWY 36 approach. & Slight \\
\hline Ring-necked Pheasant (Phasianus colchicus) & Year-round resident, airfield, Gunsmoke Hill, POL area. & High \\
\hline \multicolumn{3}{|l|}{ Rails, Gallinules, and Coots (Rallidae) } \\
\hline Moorhen (Gallinula chloropus) & Agricultural ponds adjacent to southeast edge of base. & Slight \\
\hline Ruddy crake (Porzana fusca) & Dead specimen impaled on C-wire near Big Coyote Hill. & Slight \\
\hline \multicolumn{3}{|l|}{ Plovers (Charadriidae) } \\
\hline Kentish Plover (Charadrius alexandrinus) & Common year-round, beaches at high tide. & Slight \\
\hline Little Ringed Plover (Charadrius dubius) & Year-round residents, gravel patches and roadsides. & Slight \\
\hline Mongolian Plover (Charadrius mongolus) & Spring migrant, tide line. & Slight \\
\hline Pacific Golden Plover (Pluvialis fulva) & Tidal flats. & Low \\
\hline Grey plover (Pluvialis squatarola) & Tidal flats. & Slight \\
\hline Northern Lapwing (Vanellus vanellus) & Airfield, uncommon during winter months. & Low \\
\hline \multicolumn{3}{|l|}{ Oystercatchers (Haematopodidae) } \\
\hline Eurasian Oystercatcher (Haematopus ostralegus) & Intertidal Zone especially near Big Coyote Hill. & Low \\
\hline \multicolumn{3}{|l|}{ Sandpipers (Scolopacidae) } \\
\hline Common Sandpiper (Actitis hypoleucos) & Tidal flats. & Low \\
\hline Ruddy Turnstone (Arenaria interpres) & Migrant, tidal flats and shoals. & Low \\
\hline Sharp-tailed Sandpiper (Calidris acuminata) & Rare migrant along intertidal zone & Slight \\
\hline
\end{tabular}




\begin{tabular}{|c|c|c|}
\hline Species & Typical Habitat or Location & $\begin{array}{c}\text { BASH } \\
\text { Risk }\end{array}$ \\
\hline \multicolumn{3}{|l|}{ Sandpipers - cont. } \\
\hline \multirow{2}{*}{$\begin{array}{r}\text { Dunlin (Calidris alpina) } \\
\text { Red Knot (Calidris canutus) }\end{array}$} & High tide beach and surf. & Low \\
\hline & Migrant, tidal flats and shoals. & Low \\
\hline Red-necked Stint (Calidris ruficollis) & Migrant, tidal flats and shoals. & Slight \\
\hline Great Knot (Calidris tenuirostris) & Spring and fall migrant, tidal flats and shoals. & Low \\
\hline Common Snipe (Gallinago gallinago) & Wetlands adjacent to asbestos landfill. & Slight \\
\hline Black-tailed Godwit (Limosa limosa) & Migrant, tidal flats and shoals. & Low \\
\hline Eurasian Curlew (Numenius arquata) & Year round non-breeding juvenile residents on tidal flats. & Low \\
\hline Far Eastern Curlew (Numenius madagascariensis) & Common visitor associated with Eurasian curlews on tidal flats. & Low \\
\hline Whimbrel (Numenius phaeopus) & Migrant in short grass areas (POL, golf course, airfield). & High \\
\hline Grey-tailed Tattler (Heteroscelus brevipes) & Tidal flats and tide line. & Low \\
\hline Eurasian Woodcock (Scolopax rusticola) & Drainage ditch near Haji Village. & Slight \\
\hline Wood Sandpiper (Tringa glareola) & Airfield wetlands. & Low \\
\hline Greenshank (Tringa nebularia) & Tidal flats. & Low \\
\hline Green Sandpiper (Tringa ochropus) & Airfield wetlands. & Low \\
\hline Redshank (Tringa totanus) & Tidal flats. & Low \\
\hline Terek Sandpiper (Xenus cinereus) & Tidal flats and beach at high tide. & Low \\
\hline \multicolumn{3}{|l|}{ Pratincoles (Glareolidae) } \\
\hline Oriental Pratincole (Glareola maldiarum) & Rare migrant along intertidal zone. & Slight \\
\hline \multicolumn{3}{|l|}{ Gulls (Laridae) } \\
\hline Herring Gull (Larus argentatus) & Winter resident, flocks on bars at low tide. & Moderate \\
\hline Black-tailed Gull (Larus crassirostris) & Warm season residents. & Moderate \\
\hline Black-headed Gull (Larus ridibundus) & Winter resident: flocks on bars at low tide. & Moderate \\
\hline Slaty-backed Gull (Larus schistisagus) & Small number mixed with flocks of herring gulls. & Moderate \\
\hline Little Tern (Sterna albifrons) & Common at tide line of Yellow Sea. & Low \\
\hline \multicolumn{3}{|l|}{ Pigeons (Columbidae) } \\
\hline Rock Pigeon (Columba livia) & Observed once near athletic field. & Slight \\
\hline Rufous Turtle Dove (Streptopelia orientalis) & Year-round resident, all areas. & Low \\
\hline \multicolumn{3}{|l|}{ Cuckoos (Cuculidae) } \\
\hline Common Cuckoo (Cuculus canorus) & Wolf Pack Park. & Slight \\
\hline
\end{tabular}




\begin{tabular}{|c|c|c|}
\hline Species & Typical Habitat or Location & $\begin{array}{c}\text { BASH } \\
\text { Risk }\end{array}$ \\
\hline \multicolumn{3}{|l|}{ Owls (Strigidae) } \\
\hline Brown Hawk Owl (Ninox scutulata) & POL woodlot. & Slight \\
\hline \multicolumn{3}{|l|}{ Nightjars (Caprimulgidae) } \\
\hline Jungle Nightjar (Caprimulgus indicus) & Encountered on Little Coyote, Big Coyote, and water tower hills. & Low \\
\hline \multicolumn{3}{|l|}{ Kingfishers (Alcedinidae) } \\
\hline Common Kingfisher (Alcedo atthis) & Drainage ditch in CE bulk storage area. & Slight \\
\hline Black-capped Kingfisher (Halcyon pileata) & Seawall stormwater drains. & Slight \\
\hline \multicolumn{3}{|l|}{ Hoopoes (Upupidae) } \\
\hline Hoopoe (Upupa epops) & Golf course, billeting area, Little Coyote, and airfield. & Low \\
\hline \multicolumn{3}{|l|}{ Woodpeckers (Picidae) } \\
\hline Great Spotted Woodpecker (Dendrocopos major) & POL-north area and Wolf Pack Park. & Slight \\
\hline Grey-headed Woodpecker (Picus canus) & NRMU POL-1, 2; pine row along seawall. & Slight \\
\hline \multicolumn{3}{|l|}{ Larks (Alaudidae) } \\
\hline Eurasian Skylark (Alauda arvensis) & Airfield grass in all sectors; near $8 \mathrm{FW}$ Headquarters. & Low \\
\hline \multicolumn{3}{|l|}{ Swallows (Hirundinidae) } \\
\hline Red-rumped Swallow (Hirundo daurica) & Over grassy airfield areas. & Low \\
\hline Barn Swallow (Hirundo rustica) & Over grassy airfield areas. & Low \\
\hline \multicolumn{3}{|l|}{ Wagtails and Pipits (Motacillidae) } \\
\hline Olive-backed Pipit (Anthus hodgsoni) & Wooded edges of the POL-north area. & Slight \\
\hline Buff-bellied Pipit (Anthus rubescens) & Grassy airfield areas. & Slight \\
\hline White Wagtail (Motacilla alba) & Common along seawall and grassy ditches in cantonment areas. & Slight \\
\hline Black-backed Wagtail (Motacilla lugens) & Uncommon near grassy ditches in cantonment areas. & Slight \\
\hline \multicolumn{3}{|l|}{ Bulbul (Pycnonotidae) } \\
\hline Brown-eared Bulbul (Hypsipetes amaurotis) & Woods in Wolf Pack Park and POL-north area. & Slight \\
\hline \multicolumn{3}{|l|}{ Shrikes (Laniidae) } \\
\hline Brown Shrike (Lanius cristatus) & Winter resident near Little Coyote Hill and CE bulk storage area. & Slight \\
\hline Bull-headed Shrike (Lanius bucephalus) & South security fence line. & Slight \\
\hline \multicolumn{3}{|l|}{ Thrushes (Turdidae) } \\
\hline Blue Rock Thrush (Monticola solitarius) & Buildings of Little and Big Coyote Hills. & Slight \\
\hline Daurian Redstart (Phoenicurus auroreus) & Improved and semi-improved cantonment areas. & Slight \\
\hline Common Stonechat (Saxicola torquata) & Single individual on fence adjacent to Haji Village. & Slight \\
\hline Dusky Thrush (Turdus naumann) & Flocks on the grassy cantonment areas and golf course. & Low \\
\hline
\end{tabular}




\begin{tabular}{|c|c|c|}
\hline Species & Typical Habitat or Location & $\begin{array}{c}\text { BASH } \\
\text { Risk }\end{array}$ \\
\hline Eye-browed Thrush (Turdus obscurus) & On migration through POL-north area. & Slight \\
\hline \multicolumn{3}{|l|}{ Warblers (Sylviidae) } \\
\hline Oriental Great Reed Warbler (Acrocephalus orientalis) & Tall grasses along seawall. & Slight \\
\hline Fan-tailed Warbler (Cisticola juncidis) & Wet grasslands, CE Land farm and asbestos landfill. & Slight \\
\hline Yellow-browed Warbler (Phylloscopus inornatus) & Migrant in POL woodlots. & Slight \\
\hline Crowned Willow Warbler (Phylloscopus coronatus) & Grasses along seawall and base of Little Coyote Hill. & Slight \\
\hline Goldcrest (Regulus regulus) & Small flock in pines along seawall. & Slight \\
\hline Short-tailed Bush Warbler (Urosphena squameiceps) & Foraging at base of seawall fence. & Slight \\
\hline \multicolumn{3}{|l|}{ Flycatchers (Muscicapidae) } \\
\hline Blue-and-white Flycatcher (Cyanoptila cyanomelana) & Open pine stands of cantonment area and Wolf Pack Park. & Slight \\
\hline Narcissus Flycatcher (Ficedula narcissina) & Single individual along seawall. & Slight \\
\hline Red-throated Flycatcher (Ficedula parva) & Single female individual in POL area. & Slight \\
\hline Tricolor Flycatcher (Ficedula zanthopygia) & Common in pine stands in cantonment, POL, Wolf Pack Park. & Slight \\
\hline Asian Brown Flycatcher (Muscicapa dauurica) & On migration through POL-north area. & Slight \\
\hline \multicolumn{3}{|l|}{ Flycatchers (Muscicapidae) - cont. } \\
\hline Grey-spotted Flycatcher (Muscicapa griseiticta) & On migration through POL-north area. & Slight \\
\hline \multicolumn{3}{|l|}{ Bearded Tits and Parrotbills (Panuridae) } \\
\hline Vinous-throated Parrotbill (Paradoxornis webbianus) & Thickets along south security fence, seawall. & Slight \\
\hline \multicolumn{3}{|l|}{ Tits (Paridae) } \\
\hline Coal Tit (Poecile ater) & Woodlot in POL area. & Slight \\
\hline Great Tit (Poecile major) & Year-round resident, areas with shrub and evergreen cover. & Slight \\
\hline Marsh Tit (Poecile palustris) & Common winter resident in POL-north area. & Slight \\
\hline Varied Tit (Poecile varius) & Pines of POL-north area. & Slight \\
\hline \multicolumn{3}{|l|}{ Buntings (Emberizidae) } \\
\hline Yellow-throated Bunting (Emberiza elegans) & Winter resident of dense thickets, POL and Little Coyote Hill. & Slight \\
\hline Rustic Bunting (Emberiza rustica) & Winter resident of dense thickets, POL and Little Coyote Hill. & Slight \\
\hline \multicolumn{3}{|l|}{ Finches (Fringillidae) } \\
\hline Oriental Greenfinch (Carduelis sinica) & Year-round resident, semi-improved and improved areas. & Low \\
\hline Siskin (Carduelis spinus) & Winter visitor of the cantonment area. & Slight \\
\hline Hawfinch (Coccothraustes coccothraustes) & Flock observed in pines associated with the billeting area. & Slight \\
\hline Brambling (Fringilla montifringilla) & Thickets of Wolf Pack Park and the POL area. & Slight \\
\hline Common Crossbill (Loxia curvirostra) & Pine stands associated with the billeting and Gunsmoke Hill. & Slight \\
\hline
\end{tabular}




\begin{tabular}{|c|c|c|}
\hline Species & Typical Habitat or Location & $\begin{array}{c}\text { BASH } \\
\text { Risk }\end{array}$ \\
\hline \multicolumn{3}{|l|}{ Weaver Finches (Ploceidae) } \\
\hline Tree Sparrow (Passer montanus) & Year-round resident, all areas. & Low \\
\hline \multicolumn{3}{|l|}{ Starlings (Sturnidae) } \\
\hline Grey Starling (Sturnus cineraceus) & Improved and unimproved areas. & Low \\
\hline \multicolumn{3}{|l|}{ Orioles (Oriolidae) } \\
\hline Black-naped Oriole (Oriolus chinensis) & Summer residents pair on Water Tower Hill. & Slight \\
\hline \multicolumn{3}{|l|}{ Crows (Corvidae) } \\
\hline Carrion Crow (Corvus corone) & Several pairs observed in the cantonment area. & Low \\
\hline Rook (Corvus frugilegus) & Huge flocks of winter residents on and around Kunsan AB. & High \\
\hline Daurian Jackdaw (Corvus dauuricus) & Winter residents intermixed with rook flocks. & High \\
\hline Magpie (Pica pica) & Year-round residents, all areas. & Low \\
\hline
\end{tabular}

\subsection{Airfield Management}

The vast majority of all bird-aircraft strikes occur at or near airports. The most important factor in reducing the risk of bird-aircraft strikes is a well-designed, science-based, and properly implemented airfield management program. The principal objective of Kunsan's airfield management program is to employ measures that will prevent collisions between aircraft and birds in the vicinity of the airfield. In accordance with the $8 \mathrm{FW}$ BASH Plan, the $8 \mathrm{CES} / \mathrm{CC}$ is tasked with:

a. Providing a representative to the Bird Hazard Working Group (BHWG) to monitor and advise the group on environmental modification.

b. Developing procedures for removal of bird attractants.

c. Initiating the necessary surveys and environmental impact assessments and statements on procedures to be undertaken, as required by law.

d. Developing a long-range program in conjunction with all base improvements and modifications in an attempt to make the airfield area as unattractive to birds as feasible.

e. The following general civil engineering considerations are provided to assist in these programs:

(1) Control vegetation:
(a) Mowing operations
(b) Maintaining ditches (5:1 slope)
(e) Removing dead vegetation/rubble (perches)
(c) Filling low spots
(f) Removing high spots (perches)
(d) Planting bare areas
(g) Removing edge effect
(h) Removing plants with berries 
(2) Control water:
(a) Modify ditches (slope and clear)
(c) Eliminate standing water
(b) Consider covering culverts
(d) Drain/fill in marsh areas

(3) Control waste:
(a) Collect appropriately
(b) Dispose of rapidly

(4) Control birds (chemical/physical alterations):

(a) Check for/seal potential bird accesses to buildings (hangars)

(b) Check other perches/towers, etc.

(c) Spray to control weeds and insects

(d) Use available materials to make nesting/perching unattractive

The BASH plan emphasizes the management of the airfield environment, or habitat, to discourage birds from using the airfield. In the long run, implementing those procedures is far more effective than relying on depredation. Other examples of specific recommendations that will reduce the numbers of high- and moderate-risk species on the airfield, and thereby reduce the overall BASH potential, are discussed below.

\subsection{Drainage Ditch Maintenance}

Execute the land management recommendations identified in OPLAN 91-202, Annex C.4.a.(1-4), listed above. Because the drainage gradient is slight, regrading the sides of ditches will not greatly improve the rate of drainage. However, keeping the drainage ditches clear of vegetation and debris will facilitate the flow of water, reduce habitat availability for prey species, and thereby make the ditches less attractive to birds.

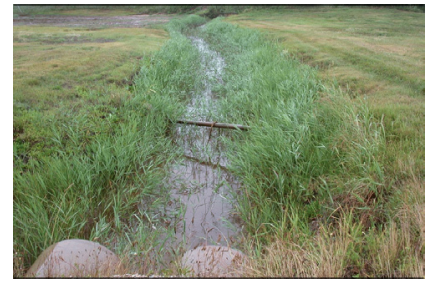

Vegetation slows flow rate of water

\subsection{Surface Water Reduction}

Establish a routine schedule to identify and fill tire ruts and other low spots around the airfield. These areas retain water and provide the habitat for reptiles, amphibians, fish, and aquatic invertebrates that attract waterfowl and wading birds.

Used widely in agriculture, buried, perforated plastic drainage tiles will enhance drainage from persistent low spots to the lower drainage ditches. The tiles would be especially effective between the perimeter road and the seawall. Drainage tile is

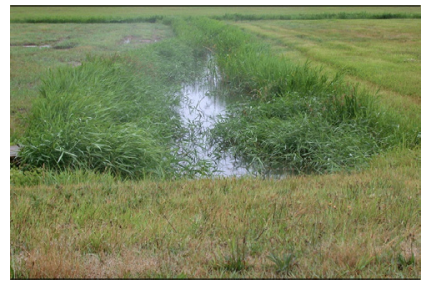

Habitat for birds and prey

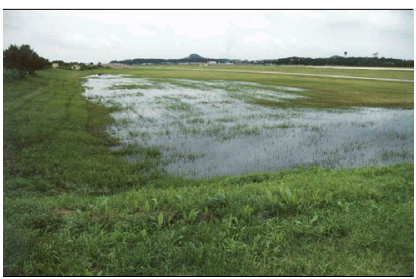

Standing water attracts birds 
lightweight and flexible, allowing for ease of use and installation. Tiles are manufactured in a variety of diameters ranging from 3 to 24 inches and lengths from 100 to 3,000 feet. Such tiles are inexpensive and able to withstand the weight of mowing tractors.

\subsection{Alternative Mowing Equipment and Procedures}

Investigate alternative mowing machines to avoid the creation of deep, water-retaining tire ruts. Alternatives might include equipping mowing machines with wide "balloon" tires that more evenly distribute the mower weight. Also, new tractors are being produced with tracks instead of conventional tires.

Design mowing patterns that employ wide turns rather than tight turns. Wider turns will reduce tire ruts. When wet, the tire ruts act as miniature ponds and harbor frogs, crabs, and other

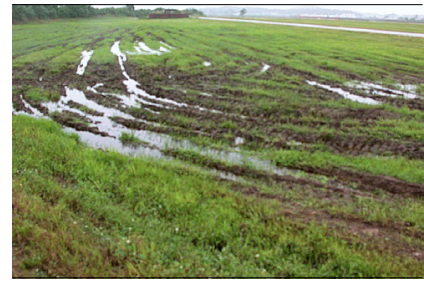

Tire ruts complicate maintenance invertebrates that attract feeding birds. The compacted soil forming the ruts retards drainage. When dry, the tire ruts prevent even mowing and increase the wear-andtear on equipment.

\subsection{Restricted Mowing Schedules}

Limit mowing activities to periods when there are no flying operations. Mowing machines disturb, maim, and disorient insects, other invertebrates, reptiles, amphibians, and even small mammals, which can attract bird predators.

Cattle egrets are naturally well adapted to foraging on the ground among animal herds. To a cattle egret, mowing machines provide the same benefits as herd animals. They have learned to associate mowing machines with an ample source of food and are particularly attracted to mowing operations. Mowing operations should be limited to non-flying hours

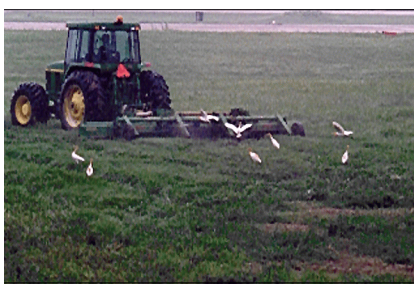

Cattle egrets follow mowing machines because the egrets frequently follow mowers to feed on the insects that are stirred up. Also, mowing activities should be avoided when the airfield is saturated or soggy. All other motor vehicle operations should be restricted on the airfield.

\subsection{Enhanced Bird Harassment}

Implement more effective harassment methods for persistent individuals (e.g., Grey Herons, Spot-billed Ducks) or flocks of birds (e.g., Cattle Egrets, Whimbrels). Procure additional gas cannons or relocate existing cannons to locations where birds congregate. Portable cannons mounted in the bed of a small pick-up truck can be moved to where birds pose the greatest hazard.

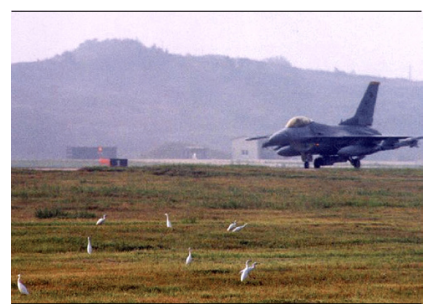

Relocate gas cannons to where birds pose the greatest risk 
Investigate the possibility of using working dogs (like border collies) for bird dispersal. Border collies have been used effectively at commercial airports and some military airfields to harass birds. Working dogs could be accommodated in existing K-9 facilities.

\subsection{Eliminating Nesting and Roosting Birds}

5.7.1 Black-crowned Night Heron Black-crowned Night Herons pose a high risk to aircraft operations. Two areas of concern exist on Kunsan AB: the north POL area and Little Coyote Hill. Pines are the dominant vegetation type in each of these areas. The key to discouraging the Black-crowned Night Heron is to monitor the areas where they roost and nest and initiate harassment techniques as soon as the birds begin to congregate early in each season.

In the spring, a flock of Black-crowned Night Herons nests in the pine stand of the central valley on the south side of Little

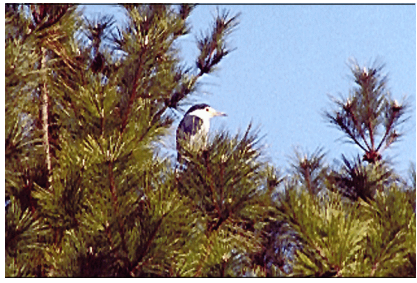

Heron roosting in POL-north Coyote Hill (NRMU LCH-2). Overlooking the Mangyeung River estuary on a steep south-facing slope, this nesting area is relatively remote and devoid of human activity. LCH-2 is shaded in red in the figure below, left. In the spring, randomly firing gas cannons can be stationed along the perimeter road to harass and discourage birds from nesting.

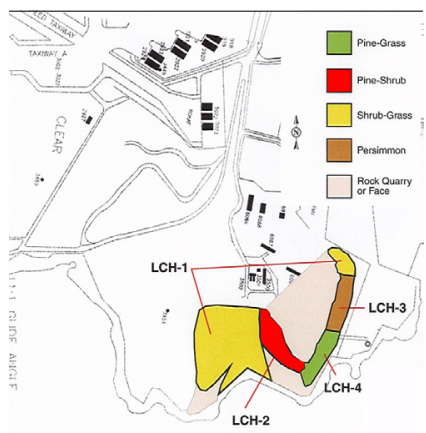

Spring nesting area in red on Little Coyote Hill

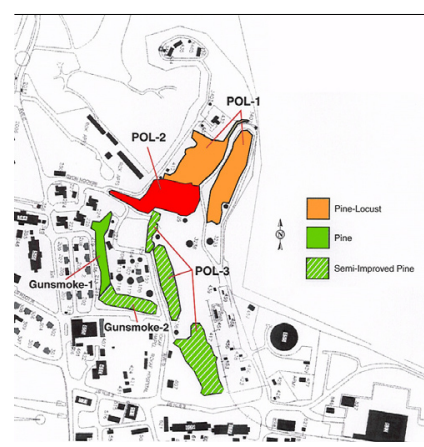

Winter roosting area in red in POLnorth

In the fall and winter, a flock of Black-crowned Night Herons roosts during the day in the pine woods inside the north POL area along Beacon Avenue. The area is identified as NRMU POL-2 and shaded in red in the figure above, right. The overstory of this NRMU is composed of two equally represented species of pine: Japanese black pine (Pinus thunbergii) and Japanese red pine (P. densiflora).

Pedestrian and vehicular traffic along Beacon Avenue does not appear to upset the roosting herons. 
However, they are very sensitive to human presence around and beneath the trees inside the fence. In the fall, daily harassment with human activity beneath the tree canopy would likely discourage the herons from using this area as a winter roosting area.

5.7.2 Rook The Rook is present in the Kunsan area only during the winter, but thousands are present during that period. Rooks begin congregating in large flocks in November and remains well into February. The Rooks roost all over the base but most notably in the pines in and around the CE complex, the Armed Forces Korea Network (AFKN) radio tower, and the Clinic. They forage for food in the agricultural fields between the seawall and the commercial airport taxiway.

The primary objective is to discourage the Rooks, specifically during flying operations, with strategically placed gas cannons that can be remotely controlled. Additional considerations to

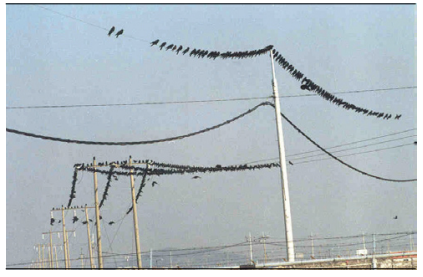

Rooks loafing near Kunsan AB reduce airfield risks include:

1. Install additional gas cannons in the field between the seawall and the commercial taxiway, or at least adjacent to the field along the fence on the west side of the commercial taxiway.

2. Determine (perhaps with the commercial airport) if the rice farmer can be subsidized not to grow rice or crops on that land and instead maintain a grass cover similar to that in the other parts of the airfield.

3. Encourage aircrews, Air Traffic Controllers, and Safety Officers to be vigilant during flying periods to assist in firing cannons and warning pilots of flocks in the vicinity.

4. Discourage flocks from roosting on base every evening, including weekends and holidays. Mobil or truck-mounted gas cannons might be used to harass birds attempting to roost in the cantonment area.

5. Remove of all extraneous roost sites. Solid waste dumpsters, especially those containing food wastes, must be kept closed at all times.

\subsection{Airfield Attractants}

In addition to being directly connected to the Yellow Sea, the drainage ditches are periodically inundated. These conditions make the airfield a preferred habitat for large populations of prey species. These species attract birds to the airfield.

The common mullet is a fish that inhabits both fresh and salt water. In the summer, mullet migrate into the brackish waters of estuaries and coastal streams. To the mullet, the drainage ditches of the Kunsan airfield mimic that environment. In the winter, they migrate back to the sea. Mullet frequently jump out of the water. Wading birds are attracted to the airfield ditches by the leaping and often visible mullet. In the cramped environment of the ditches, the mullet become easy prey for the wading birds. By covering the open drainage ditches between the runway and Perimeter Road has been very effective in reducing the habitat for mullet. The closed concrete culverts effectively moves water away from the main base and airfield. But the 
culverts are tightly fitted and they have created other problems. For example, they inhibit the lateral flow of water from the grassy area between the ditches into the drainage ditches. The result is saturation and ponding on the airfield for longer periods following precipitation events. Some of the areas appear to have become permanently saturated and have formed attractive wetland habitats.

All land crabs live in burrows or beneath stones. The banks of the airfield drainage ditches and the adjacent ground surface are riddled with the tell-tale, one-inch-diameter holes excavated by land crabs. The high water table on the airfield grounds is a significant factor contributing to their presence. The populations of land crabs are very high, and at least two species of the order Ocypodidae are commonly observed navigating through the airfield grasses: grapsid crabs and sesarmine crabs.

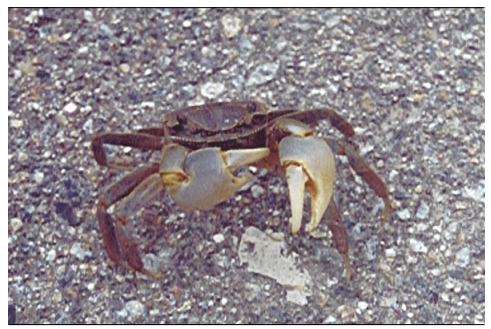

Grapsid crab - Helice formosensis

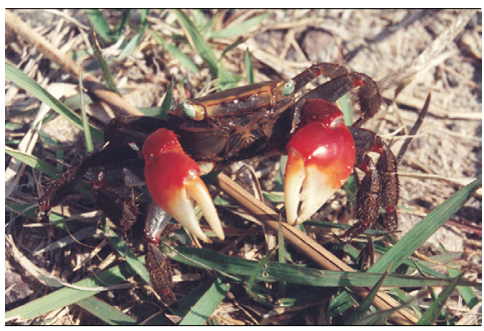

Sesarmine crab - Chiromantes haematocheir

Grapsid crabs can be found in burrows along the ditches and occasionally out of the water sunning themselves. The sesarmine crabs are primarily terrestrial and are most often encountered foraging in the airfield's grass. Both are detritovores and scavengers. Although they can run rapidly and demonstrate a menacing defensive posture, the land crabs are easy prey for larger wading birds, including egrets, Whimbrels, curlews, and herons.

It would be desirable to bury a network of drainage tiles between the ditches to enhance drainage from the airfield. Such action would reduce the wetland habitat and help to reduce the land crab population from the immediate vicinity of the airfield. 
This Page

Intentionally

Blank 


\section{References and Literature Cited}

Barter, M.A., 2002. The Yellow Sea and Its Shorebirds, Oriental Bird Club Bulletin 37:35-42.

Bhushan, B., G. Fry, A. Hibi, T. Mundkur, D.M. Prawiradilaga, K. Sonobe, and S. Usui, 1993. A Field Guide to the Waterbirds of Asia, Kodansha International, Tokyo, Japan.

Brazil, M.A. 1991. The Birds of Japan, Smithsonian Institution Press, Washington, D.C.

Harrison, P., 1983. Seabirds, An Identification Guide, Houghton Mifflin Company, Boston, Mass.

Hayman, P., J. Marchant, and T. Prater, 1986. Shorebirds, An Identification Guide, Houghton Mifflin Company, New York, NY.

INRMP, 2004. Integrated Natural Resources Management Plan, Revision 1, 2003-2007 for Kunsan Air Base, prepared for the Environmental Flight, 8 Civil Engineer Squadron, Kunsan Air Base, Republic of Korea by Argonne National Laboratory, Argonne, Ill.

Kaufman, K., 1997. Kingbird Highway: The Story of a Natural Obsession That Got a Little Out of Hand, Houghton Mifflin Company, New York., NY.

Lee, W.S., T.H. Koo, and J.Y. Park, 2000. A Field Guide to the Birds of Korea, Toyokan Publishing Co., Ltd. Tokyo, Japan.

Madge, S., and H. Burn, 1988. Waterfowl, An Identification Guide to the Ducks, Geese, and Swans of the World, Houghton Mifflin Company, Boston, Mass.

Massey, J.A., S. Matsui, T. Suzuki, E.P. Swift, A. Hibi, N. Ichida, Y. Tsukamoto, and K. Sonobu, 1982. A Field Guide to the Birds of Japan, Kodansha International, Tokyo, Japan.

Moores, N., 2002. Wetlands: Korea's Most-Threatened Habitat, Oriental Bird Club Bulletin 36:54-60.

Moores, N., and C. Moores, 2003. Saemangeum - A Vital Wetland, Oriental Bird Club Bulletin 37:47-49.

National Geographic Society, 1999. Field Guide to the Birds of North America, National Geographic Society, Washington, D.C.

Ralph, C.J., G.R. Geupel, P. Pyle, T.E. Martin, and D.F. DeSante, 1993. Handbook of Field Methods for Monitoring Land birds, Gen. Tech. Rep. PSW-GTR-144-www, Pacific-Southwest Research Station, Forest Service, U.S. Department of Agriculture, Albany, Calif. 
This Page

Intentionally

Blank 


\section{Index of Scientific and English Common Names}

Scientific nomenclature follows Lee et al. (2000) in nearly all cases. Exceptions include the Great Egret (formerly Egretta alba) which is now Ardea alba. The tits, formerly of the genus Parus, are now included in the genus Poecile.

Accipiter

nisus .................... 27

soloensis ................. 26

Acrocephalus orientalis . . . . . . . . . 97

Actitis hypoleucos .............. 55

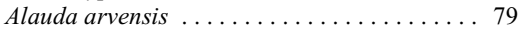

Alcedo atthis ................ 74

Anas

acuta .................... 19

americana ................... 20

сrecca .................. 23

penelope.................. 20

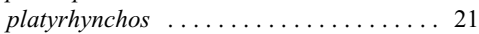

poecilorhyncha ............... 22

strepera ................. 24

Anthus

hodgsoni ................ 85

rubescens ................. 84

Ardea

alba .................... 13

cinerea ..................... 16

Arenaria interpres .............. 48

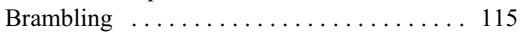

Bubulcus ibis ................. 12

Bulbul, Brown-eared ............. 86

Bunting

Rustic .................. 111

Yellow-throated ............... 112

Buteo buteo .................... 28

Butorides striatus . . . . . . . . . . . . . 11

Buzzard, Common . . . . . . . . . . . . . 28

Calidris

acuminata ................ 44

alpina ............................... 45

canutus................... 46

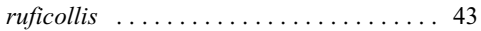

tenuirostris . ............. 47

Caprimulgus indicus . . . . . . . . 72

Carduelis

sinica . . . . . . . . . . . . . . . . 113

spinus . . . . . . . . . . . . . . 114
Charadrius

alexandrinus ............. 27

dubius ................................. 36

mongolus .............................. 38

vociferus ........................ 36

Cisticola juncidis . ............. 94

Coccothraustes coccothraustes . . . . . 117

Columba livia .................. 68

Cormorant, Great ............. 9

Corvus

corone .................. 124

dauuricus ................. 122

frugilegus ........................... 123

Coturnix japonica ............. 33

Crake, Ruddy ................ . 34

Crossbill, Common ............ 116

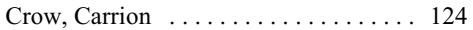

Cuckoo

Common ................ 70

Indian . . . . . . . . . . . 70

Little ................. 70

Oriental ................ 70

Cuculus canorus ............. 70

Curlew

Eurasian ............................ 57

Far Eastern ................ 58

Cyanoptila cyanomelana .......... 105

Dendrocopos major . . . . . . . . . . . 77

Dove

Rock .................. 68

Rufous Turtle ............... 69

Duck, Spot-billed .............. 22

Dunlin ................... 45

Egret

Cattle ................. 12

Great $\ldots \ldots \ldots \ldots \ldots \ldots \ldots \ldots$

Intermediate . . . . . . . . . . . . 14

Little .................... 15

Egretta

alba ................. 13

garzetta ............................... 15

intermedia ................ 14 
Emberiza

elegans................... 112

rustica ..................... 111

Eurystomas orientalis . ........... 75

Falco

peregrinus .................. 29

subbuteo .................. 30

tinnunculus ................ 31

Falcon, Peregrine . . . . . . . . . . . . . . . . 29

Ficedula

narcissina ................. 101

parva ...................... 104

zanthopygia .............. 100

Flycatcher

Asian Brown ................. 103

Blue-and-White ................. 105

Grey-spotted ................. 102

Narcissus . . . . . . . . . . . . . . . . . 101

Red-throated ................. 104

Tricolor ..................... 100

Fringilla montifringilla ............ 115

Gadwall ........................ 24

Gallinago gallinago ............... 60

Gallinula chloropus ................. 35

Glareola maldivarum ............... 62

Godwit, Black-tailed ............. 56

Goldcrest ...................... 96

Greenfinch, Oriental .............. 113

Greenshank .................. 50

Gull

Black-headed ................. 64

Black-tailed ................6 63

Herring . . . . . . . . . . . . . . 65

Slaty-backed ...............66 66

Haematopus ostralegus . . . . . . . . . . . 42

Halcyon pileata . . . . . . . . . . . . . . 73

Hawfinch ....................... 117

Heron

Grey ................... 16

Striated ................. 11

Heteroscelus brevipes . . . .......... 54

Hirundo

daurica.................. 81

rustica ................. 80

Hobby, Eurasian . . . . . . . . . . . . . . 30

Hoopoe . . . . . . . . . . . . . . . . 76

Hypsipetes amaurotis . . . . . . . . . . . 86

Jackdaw, Daurian ................. 122
Kestrel, Common . . . . . . . . . . . . . 31

Killdeer ................. 36

Kingfisher

Black-capped ............. 73

Common ................ 74

Knot

Red ................ 46

Great ................ 47

Lanius

bucephalus ............... 87

cristatus ................ 88

Lapwing, Northern . . . . . . . . . . . 41

Larus

argentatus ..............66 65

crassirostris .............663

ridibundus ..............664

schistisagus .............66 66

Loxia curvirostra . . . . . . . . . . . . . 116

Limosa limosa . . . . . . . . . . . . 56

Magpie, Black-billed ............ 121

Mallard . . . . . . . . . . . . . . . . 21

Merganser, Red-breasted .......... 25

Merganser serrator ............ 25

Monticola solitarius . . . . . . . . . . . . 91

Moorhen .................... 35

Motacilla

alba .................. 82

lugens ................. 83

Muscicapa

dauurica.............. 103

griseisticta ............. 102

Night Heron, Black-crowned . . . . . . . 10

Nightjar, Jungle . . . . . . . . . . . . . 72

Ninox scutulata . . . . . . . . . . . . 71

Numenius

arquata .............. 57

madagascariensis ........... 58

phaeopus ................ 59

Nycticorax nycticorax .......... 10

Oriole, Black-naped . . . . . . . . . . . 120

Oriolus chinensis ............... 120

Owl, Brown Hawk . . . . . . . . . . . . 71

Oystercatcher, Eurasian . . . . . . . . . . 42

Paradoxornis webbianus . . . . . . . . 106

Parrotbill, Vinous-throated ........ 106 Parus

ater.................. 109

major .............. 110 
palustris ................. 108

varius ................... 107

Passer montanus .................. 118

Phalacrocorax carbo ............... 9

Phasianus colchicus ................ 32

Pheasant, Ring-necked . . . . . . . . . . . 32

Phylloscopus

coronatus ...................... 99

inornatus . . . . . . . . . . . . . . . 98

Phoenicurus auroreus .............. 89

Pica pica .................... 121

Picus canus ................. 78

Pintail, Northern . . . . . . . . . . . . . . . . . 19

Pipit

American ................. 84

Buff-bellied ............... . 84

Olive-backed .............. 85

Platalea

leucorodia .................................. 17

minor ................... 17

Plover

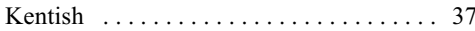

Grey .................... 40

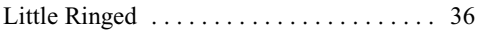

Mongolian ................. 38

Pacific Golden . . . . . . . . . . . . . . 39

Snowy .................. 37

Pluvialis

fulva .................... 39

squatarola ............... 40

Poecile

ater.................... 109

major ................. 110

palustris .................. 108

varius ................... 107

Porzana fusca .................. 34

Pratincole, Oriental ............... 62

Quail, Japanese .................. 33

Redshank, Common ................. . 49

Redstart, Daurian . . . . . . . . . . . . 89

Regulus

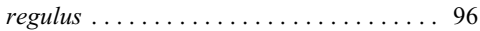

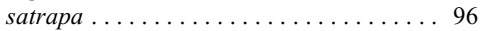

Roller, Broad-billed ................ 75

Rook ...................... 123

Sandpiper

Common $\ldots \ldots \ldots \ldots \ldots \ldots \ldots \ldots 5$

Green ................... 51
Sharp-tailed $\ldots \ldots \ldots \ldots \ldots \ldots \ldots 44$

Terek ..................... 52

Wood .................. 53

Saxicola torquata ............. 90

Scolopax rusticola . ............ 61

Shelduck, Common .............. 18

Shrike

Brown ............... 88

Bull-headed .............. 87

Siskin ................... 114

Skylark, Eurasian . . . . . . . . . . . . 79

Snipe, Common ............. 60

Sparrow, Tree ............. 118

Sparrowhawk

Chinese ............... 26

Eurasian ................ 27

Spoonbill

Black-faced ............... 17

Eurasian ................. 17

Starling, Grey . . . . . . . . . . . . . . 119

Sterna albifrons . . . . . . . . . . 67

Stint, Red-necked ............... 43

Streptopelia orientalis . . . . . . . . . 69

Stonechat, Common ............... 90

Sturnus cineraceus . .............. 119

Swallow

Barn ................... 80

Red-rumped ............. 81

Tadorna cristata $\ldots \ldots \ldots \ldots \ldots \ldots \ldots$

Tattler, Grey-tailed . . . . . . . . . . . 54

Teal, Common ................ 23

Tern, Little . . . . . . . . . . . 67

Thrush

Blue Rock . . . . . . . . . . . . . 91

Dusky ................. 92

Eye-browed ............. 93

Tit

Coal .................. 109

Great ................ 110

Marsh ................... 108

Varied ................ 107

Tringa

glareola ................ 53

nebularia ................ 50

ochropus ................ 51

totanus .................. 49

Turdus

naumann .............. 92 
obscurus ................................. 93

Turnstone, Ruddy . . . . . . . . . . . . . 48

Upopa epops ................. 76

Urosphena squameiceps . . . . . . . . . . 95

Vanellus vanellus . ................ 41

Wagtail

Black-backed . . . . . . . . . . . . 83

White .................... 82

Warbler

Eastern Crowned Willow ... . . . . . . . 99

Fan-tailed . . . . . . . . . . . . . . 94

Oriental Great Reed . . . . . . . . . . . 97

Short-tailed Bush . . . . . . . . . . . . . . 95

Yellow-browed ............. 98

Wigeon

American .................. 20

Eurasian ................... 20

Whimbrel ......................... 59

Woodcock, Eurasian .............. 61

Woodpecker

Grey-headed ................ 78

Great Spotted . . . . . . . . . . . . . . 77

Xenus cinereus ................... 52 